\title{
Unveiling the actual progress of Digital Building Permit: getting awareness through a critical state of the art review
}

\author{
Francesca Noardo ${ }^{a}$, Dogus Guler ${ }^{b}$, Judith Fauth ${ }^{c}$, Giada Malacarne ${ }^{d}$, Silvia Mastrolembo Ventura ${ }^{\mathrm{e}}$, Miguel \\ Azenha ${ }^{\dagger}$, Per-Ola Olsson ${ }^{g}$, Lennart Senger ${ }^{h}$ \\ a3D Geoinformation, Delft University of Technology, Delft, The Netherlands \\ ${ }^{b}$ Department of Geomatics Engineering, Istanbul Technical University, Istanbul, Turkey \\ ${ }^{c}$ Department of Construction Engineering and Management, Bauhaus University Weimar, Weimar, Germany \\ ${ }^{d}$ Fraunhofer Italia Research, Bolzano-Bozen, Italy \\ ${ }^{e}$ Department of Civil, Environmental, Architectural Engineering and Mathematics, University of Brescia, Brescia, Italy \\ ${ }^{f}$ University of Minho, ISISE, Department of Civil Engineering, Guimarães, Portugal \\ ${ }^{g}$ Department of Physical Geography and Ecosystem Science, Lund University, Sweden \\ ${ }^{h}$ Institute of Construction Management and Digital Engineering, Leibniz Universität Hannover, Hannover, Germany
}

\section{Abstract}

Growing interest is awarded to the digitalization of the building permitting use case and many works are developed about the topic. However, the subject is very complex and many aspects are usually tackled separately, making it very hard for traditional literature reviews to grasp the actual progress in the overall topic. This paper unveils the detailed state of the art in Digital Building Permitting (DBP) by critically analyzing the literature by means of a set of coding tags (research progress, implementation, affected DBP workflow steps, ambitions addressed) assigned by a multidisciplinary team. The mainly addressed aspects of the digitalization of building permits resulted to be the technologies to check the compliance of design proposals against regulations, followed by the digitalization of regulations. Lacking aspects are instead the involvement of officers, scalability of solutions and interoperability of data, intended both as data validation and as integration of geoinformation with building models.

Keywords: Digital building permit, BIM, GIS, GeoBIM, Compliance checking, Rule checking.

\section{Introduction}

A building permit is the authorisation to start the construction phase of a building project, granted by public authorities. It is part of a process of town planning that ensures that the requirements, set to ensure a sufficiently high quality, are met for new constructions, in order to guarantee a sustainable and controlled development of the built environment, benefiting communities, environment and economy [1, 2]. Several aspects are involved,

Email address: f.noardo@tudelft.nl (Francesca Noardo) 

ment, environmental quality (noise, shadow, pollution, temperature), accessibility and more. As it is clear from such definition, several skills and disciplines are involved in the building permit use case.

From recent years, an international push to digitalization, which is now enabled by the progress of technologies, is being promoted in managing data and processes in the Architecture, Engineering, Construction (AEC) innovation opportunities, including the field of building permits and compliance checks [4]. However, this also presents many related challenges in terms of knowledge gaps, technology deployment, standards, and the regulatory and policy context. First, the topic of building permitting itself is very complex: many sub-issues have to be solved for each of the steps involved in a possible digital workflow for building permit issuing. Another major point of complexity is the necessary diversity in the expertise and points of view to be involved and collaborate for the success of such digitalization. For this reason, there are also works intended to establish a common ground of concepts and terms to be used for the topic. For example, Hjelseth [5] proposes a framework to uniquely classify the different kinds of model checking concepts.

Many researchers have investigated the topic with respect to the many parts of which it is composed, sometimes proposing algorithms applying their findings (e.g., [6]). Moreover, several examples exist, where experiments, initiatives and pilots have been developed, together with demonstrators and more complete implementations, with different levels of progress. Therefore, the current knowledge achieved about the building permit digitalization and automation and the related implementations consist of a large amount of contributions from both academia and industry. However, such solutions remain somehow fragmented because of the fact that, due to the challenge represented by the many sub-issues entailed, they usually refer to few specific parts of the more complex workflow and related issues. Critical step to grasp the actual progress in the topic is to build a clear overview of the existing efforts with reference to a common framework in order to depict the complexity of the topic itself. For this reason, such an overview is the subject of this paper, with the final goal of supporting a consistent action plan, building upon the current efforts, understood and interpreted with respect to the overall topic.

Literature review works were already published previously: they mainly consider automated code compliance checking while introducing and comparing the state of the art [7, 8, 9]. Automated code compliance checking is pretty much related to building permitting, but it does not cover the whole topic thoroughly. Ponnewitz and Schneider [10] proposed a review searching for process investigations regarding BIM-based building permitting. However, an overall review which classifies the very diverse publications in building permitting according to detailed criteria and refers to the specific components of the complex issue and workflow of digital building permitting is missing so far. This paper analyzes the available literature on digital building permitting by considering the specific scope of each item. It allows unveiling a reliable picture on the current state of the art of each part of the digital building permitting process, enabling considerations on the overall progress and detecting 
65 the major gaps.

This paper is structured as follows: Section 2 provides an overview on the topic of the digitalization process of building permitting. The parts composing the overarching topic are explained in the subsections 2.1 to 2.3. In particular, the need for managing changes in operational workflows within public administrations, including small-sized municipalities, to manage both innovate processes and the new kinds of data, now digital data, is outlined in Section 2.1. At the end of this section, a building permit workflow is selected and mapped as a reference and the related steps are reported as a common framework. An introduction about the involved digital data, as three-dimensional (3D) information systems, follows in Section 2.2, together with the respective open standards and the efforts and challenges for their integration. Moreover, Section 2.3 shortly reports on the European network for Digital Building Permit (EUnet4DBP), multi-disciplinary and multi-sectoral collaboration within which the work described in this paper was performed. The research methodology that has been adopted for the development of this review is described in Section 3. The results are finally presented in Section 4 and discussed in Section 5, from where it is possible to point out the specific gaps in the overall development of building permit digitalization. Section 6 concludes the paper.

\section{The digitalization of building permits}

The recent progress in software and hardware have made it possible to aspire to the great potential given by digitalization in terms of both workflows and data management for the practice of many processes and in many fields. Therefore, large resources are being invested worldwide, for example in the AEC industry, in public administration processes, in information production, management and analysis.

The building permit process is considered among the most promising use cases for automation via digital processes and digital data about buildings and the built environment, bringing relevant savings with respect to the current processing [11, 12], which is still mostly manual in the great majority of cases. Figure 1 presents the evolution of the building permitting from the traditional paper-based analogue process to a fully digitalized model-based setting.

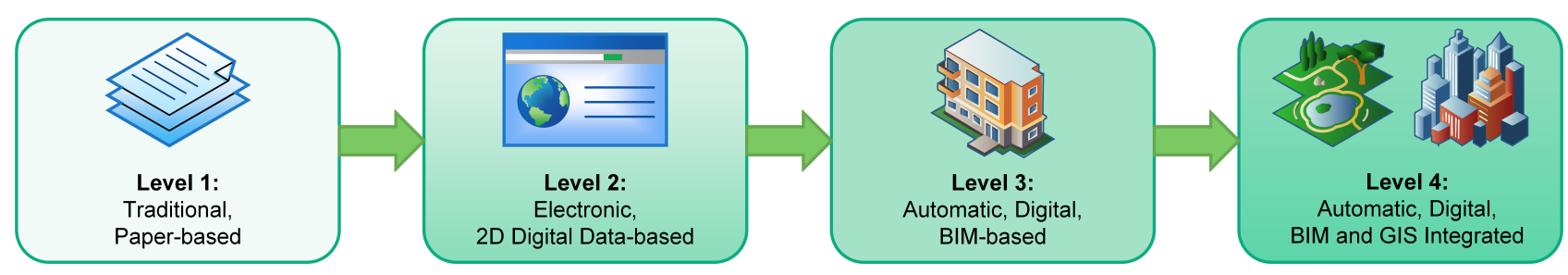

Figure 1: Evolution of building permit issuing (adapted from Shahi et al. [13]).

Several studies have investigated the state of practice and workflows, by sending questionnaires, interviewing 
to quantify the potential advantages related to the digitalization of building permitting in terms of economic savings and efficiency increase. Plazza et al. [14] analyzed the process in Italy, while Samasoni et al. [15] studied the New Zealand case, calculating economic benefits due to the use of such a system of approximately $\$ 67.3$ millions per year, taking into account the time saved by both applicants and building authorities, as well as benefits to contractors. From an Estonian report of the project introducing DBP in the country [16], a cost/benefit analysis revealed a potential saving of more than $€ 500,000$ per year, without considering the advantages and savings given by the improvement in rules clarity and interpretations, which are pointed out as source of time and effort savings also from the designers' side. A report by AS PricewaterhouseCoopers Advisors [17] also highlights a possible saving of 45 FTEs (full time equivalent) workforce per year, with an increase in efficiency of about $8-10 \%$ in workload. Such saved resources could instead be dedicated to a more careful check of noncompliance, the most complex cases and more advanced analysis that could help solving issues currently reported (e.g., exemptions, specific cases, specific plan needs), with a general increase of the quality of the built environment and of the job task. In addition, the proceedings burden would be reduced. The same concepts are confirmed by the Centre for Digital Built Britain (cdbb) report [18], in the United Kingdom (UK). According to the report, digitalizing and automating the system could enable a new level of transparency, and inherently build in the so-called "Golden Thread of information"1. Although these numbers are presented outside their context and come from different cases, they all demonstrate a positive impact deriving from the introduction of a DBP system. The building permit use case is therefore among the priorities for the digitalization process for public authorities. It is also expected that the digitalization of building permitting aids to economic development and housing in the context of smart city [19].

Consequently, national and international legislation is moving in the direction that promotes digital transition for construction industry (see, for example the Directive 2014/24/EU of the European Council on public procurement $^{2}$ ). The European Commission $(E C)^{3}$ recently announced that a framework that enables digital permitting in the built environment will be developed within the renovation wave for Europe. However, the current practice is still far from the objective: in the vast majority of cases, a manual building permit process is still used, entailing subjective, error-prone, and time-consuming tasks and decisions, with high risk of ambiguity, inconsistency in assessments and delays over the entire construction process [20].

The process of issuing a building permit consists of several steps, with a great number of stakeholders involved, using many pieces of information. In many countries this (rather diverse) information is still handled in analogue formats (or, at best, PDF documents) and in bi-dimensional graphic representations. Moreover, in practice, the involved procedures and data are very heterogeneous and, in most cases, they can also be relatively informal - e.g., decisions depend on the local knowledge and expertise of individuals. These aspects make the transformation of the process challenging, since it is composed of many small issues to be solved separately,

\footnotetext{
${ }^{1}$ https://www.bimacademy.global/insights/infrastructure/the-golden-thread-of-information-putting-the-hackitt-r eport-into-practice/

${ }^{2}$ https://eur-lex.europa.eu/legal-content/EN/TXT/?uri=celex\%3A32014L0024

${ }^{3}$ https://eur-lex.europa.eu/resource.html?uri=cellar:0638aa1d-0f02-11eb-bc07-01aa75ed71a1.0003.02/D0C_1\&format= PDF
} 
but still needing important reciprocal coordination and collaboration between several stakeholders and several different disciplines (e.g., code checking, building design, geoinformation management).

Several examples exist about the value of reusing and analyzing (digital) building permit data. Gauthiez and Zeller [21] map the urban growth in the city of Lyon in the 17th and 18th century with the help of a Geographical Information Systems (GIS). To restructure the organizational structure of the building permit authorities and to optimize the building permit process in Prague, Hainc et al. [22] analyzed the building permit data. Using census data, investigations of urban or residential growth related to the real estate market is exemplary proposed by Davis and Schaub [23], Shakro [24], and Cellmer and Jasiński [25]. All approaches reflect the significance and the wide range of opportunities of accessible DBP-related data.

\subsection{A reference, digital-enabling, building permitting workflow}

As previously mentioned, even the current mostly (paper) document-based building permitting is a very complex topic, articulated in many small components, characterized by high levels of multidisciplinary and intersectoral involvement. The first step towards the change was therefore the definition of how such a workflow should be changed in order to take advantage of digital data and digital tools, without neglecting the needs and the steps foreseen by more traditional procedures.

Several works are intended to solve this issue, with different levels of insight [14, 26, 27, 28, 29, 30]. One example [31] was developed within the EuroSDR GeoBIM project ${ }^{4}$ by first harmonizing the workflows in use in the countries participating in the project, together with others found in literature [32]. On this base, changes useful to facilitate the use of digital data (e.g., 3D city models and Building Information Modelling (BIM) models) by digital and (semi)automated tools were proposed, resulting in the workflow outlined in Noardo et al. [31], the draft of which was validated by several municipalities in the participating countries.

The conversion of the current, analogue workflows to digital workflows would, without doubt, requires an indepth investigation itself. However, for the aims of this paper, and after checking for consistency with some other proposed examples [13, 33, 34, 32], we consider the steps depicted in Figure 2 as a reference to investigate and code the state of the art of previous research efforts in the digitisation of building permitting.

Figure 2 illustrates the considered workflow steps 1-8 and their assignment to the parties in the DBP process. Each step is assigned to either the applicant or the authority (e.g., municipality). In some situations, the step can be assigned to both parties. This means that both parties perform this step together or either one or the other is responsible for the respective step.

\footnotetext{
${ }^{4}$ https://3d.bk.tudelft.nl/projects/eurosdr-geobim/
} 


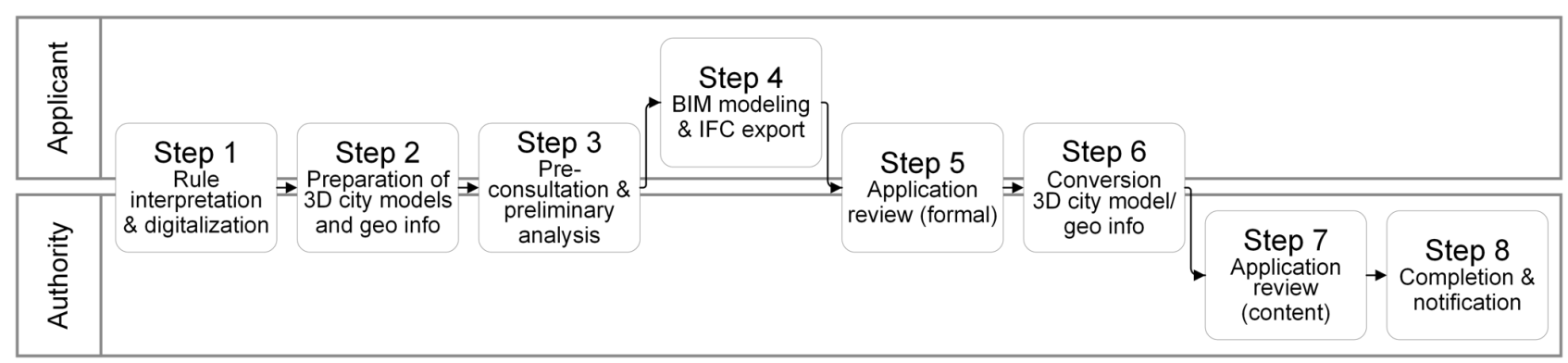

Figure 2: Schematic overview of considered workflow steps assigned to involved parties.

\subsection{From paper-based documents to digital information systems: digital data for DBP}

The key enabling factor to make the digitalization of building permit process achievable was the development of relatively new kinds of data and the technologies to produce and use them. The traditional process is based on two-dimensional (2D) documents representing plans, facades and sections of the designed new building drawn according to orthogonal projections, and the context is usually represented by means of the technical and cadastral maps of the city. Even in the early examples of digital platforms to manage the building permit applications and documentations, when a dematerialization approach was implemented rather than a digitalization approach, those kinds of deliverables were the reference approaches, submitted as paper or in PDF format. However, such kinds of documents can only be analyzed manually, without offering any potential towards automation. On the other hand, powerful information systems have been developed in the two main fields involved in building permit (city representation and building design), allowing a complex and hierarchical representation of both semantic information and geometry. Information systems allow a more complex data management as well as the automatic analysis of the obtained models; moreover, they enable collaboration environments to manage digital workflows. The following subsection 2.2.1 introduces the adoption of BIM models in the field of building design. Subsection 2.2.2, describes GIS and their 3D evolution as 3D city models. The issue of their integration in a GeoBIM environment is addressed in subsection 2.2.3.

\subsubsection{Building information models and related open standards}

BIM, which is now understood as an expression of digital innovation across the construction industry, is known as "a set of technologies, processes and policies" 5 enabling the "use of a shared digital representation" of a facility (i.e., building and infrastructure) through its life cycle in order "to form a reliable basis for decisions" [35] in a collaborative environment. A BIM model, in particular, is an object-oriented, data-rich, 3D parametric digital model generated during the modelling process and potentially containing, according to specific use cases, from the smallest elements of a building (e.g., bolts) to the construction site, following consequent semantic structures [36]. The adoption of BIM is exponentially increasing in different sectors, particularly in the AEC

\footnotetext{
${ }^{5}$ https://bimdictionary.com/ Accessed on 10th September 2021
} 
industry [37]. Reference standard for BIM-based data exchange and interoperability is the Industry Foundation Classes (IFC) by buildingSMART ${ }^{6}$. IFC is a standardized, digital description of the built environment, including buildings and infrastructures. It is an open, international standard [38] meant to be vendor-neutral and de-

\subsubsection{Geoinformation and related open standards}

Geoinformation is intended to represent the entire city and wider pieces of land, which are the context of the new planned buildings. Besides traditional maps produced by cartography, the digital version of such maps are managed by means of GIS, and their 3D versions, the 3D city models. Geoinformation plays an essential role in the analysis of a city $[39,40,41,42,43]$ and could be effectively used in the assessment of the reciprocal impacts of the new construction and the city.

Several data models exist to structure digital maps and 3D city models, usually developed according to the needs of different cities or different countries, therefore several national data structures exist. In order to obtain internationally interoperable data, further schemas are provided by sovra-national organizations, that are usually considered by the studies intending to provide replicable solutions. Among the most popular data schemas are the data model proposed by the European Directive for a Spatial Data Insfrastructure (INSPIRE) ${ }^{10}$ and CityGML, by the Open Geospatial Consortium (OGC) ${ }^{11}$, adopted in its original version or by means of national Application Domain Extensions (ADEs) [44] in several cities and countries. However, for several reasons, among which the fact that such models are intended for a very wide scope, they are very complex and quite difficult to be implemented [45], also for being based on the Geography Markup Language (GML) format. Recently, CityJSON ${ }^{12}$ was proposed as an alternative solution and approved by OGC, starting from

\footnotetext{
${ }^{6}$ https://technical.buildingsmart.org/standards/ifc/ Accessed on 10th September 2021

${ }^{7}$ https://technical. buildingsmart.org/standards/bcf / Accessed on 10th September 2021

${ }^{8}$ https://technical.buildingsmart.org/standards/ifc/mvd/ Accessed on 10th September 2021

9 https://technical.buildingsmart.org/projects/information-delivery-specification-ids/ Accessed on 10th September 2021

${ }^{10}$ https://inspire.ec.europa.eu

${ }^{11}$ https://www.ogc.org/standards/citygml

${ }^{12}$ https : //www. cityjson.org and https ://docs.ogc.org/cs/20-072r2/20-072r2.html
} 
a different implementation of the CityGML v.2.0 schema [46] and was proved to be very effective from an implementation point of view [47, 48, 49, 50, 51].

\subsubsection{GIS-BIM integration (GeoBIM)} elaborated by a restricted team of the EUnet4DBP in order to make them clearer and consistent. A relevant part

\footnotetext{
${ }^{13}$ https://3d.bk.tudelft.nl/projects/eunet4dbp/ Accessed 10th September 2021
} 
of the methodology for writing this paper was about associating the EUnet4DBP ambitions and requirements to each reviewed document as coding tags, so that we can also picture how much each of the ambitions and requirements are addressed at the moment (see Section 3.2). During this process, it was possible for the authors to point out the remaining ambiguities of the formulated statements. Discussing their meaning and relevance was a great opportunity to re-define them in a clearer way and adding explanations and examples (see Table 1 and Table 2 for ambitions and requirements respectively).

\section{Methodology}

The literature review described in this paper includes both scientific and technical contributions, retrieved and analyzed following the research methodology illustrated in Figure 3.

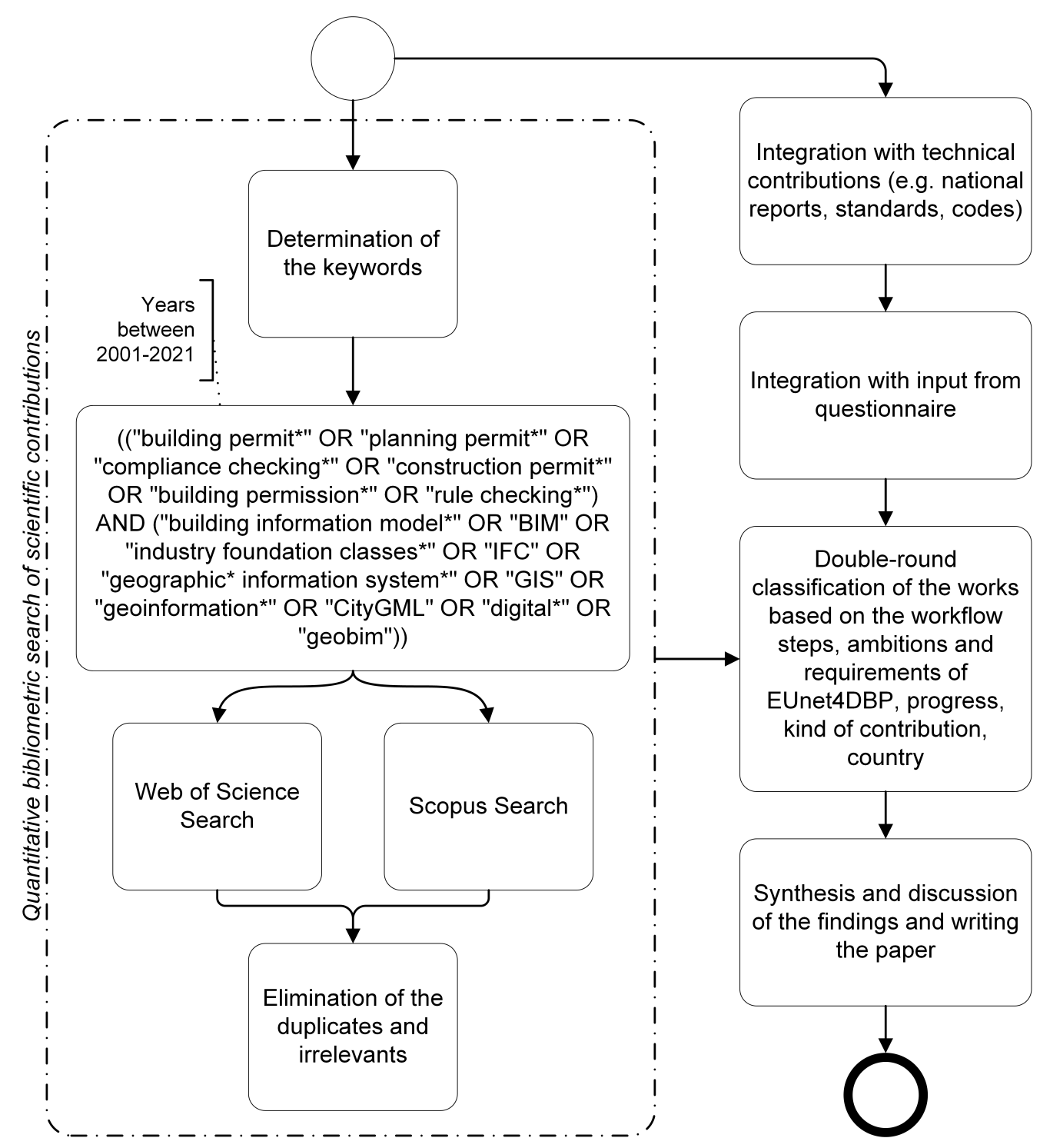

Figure 3: Methodology of the paper.

It began with the collection of contributions by the listed keywords in Figure 3, as proposed and agreed by the authors. The retrieved papers were object of an initial bibliometric analysis about DBP (Section 3.1). The scope 
of the bibliometric study relies on analyzing trends, in the field of DBP in order to evaluate the international outside the indexed scientific databases, but building up towards a progress on the topic as well. Among these we can list: non-indexed journal and conference papers; technical reports; MSc theses; tools and codes.

Further integration came from the experience of the authors and of other DBP experts, contacted both through

${ }^{14}$ https://3d.bk.tudelft.nl/projects/eunet4dbp/events.html\#i-eunet4dbp-international-workshop-on-digital-buildin g-permit Accessed 22nd October 2021

15 https://www.scopus.com/search/form.uri?display=basic\#basic

16 https://www. webof science.com/wos/woscc/basic-search

${ }^{17}$ https://ieeexplore.ieee.org/Xplore/home.jsp 
the EUnet4DBP and in the context of the First EUnet4DBP workshop (1EUnet4DBPws) ${ }^{18}$ by means of a questionnaire. The relevant contributions submitted to the 1EUnet4DBPws [66] were also associated to the workflow's steps to integrate the picture of the progress related to each step. The scope of the questionnaire was to collect the existing experiences, known by the members of the EUnet4DBP or attendants of the 1EUnet4DBPws (25-26 March 2021), on the digitization of the building permit process.

After a short introduction about the scope of the questionnaire, the participants were asked to report initiatives

\subsection{Coding schema for the classification of the collected contributions}

The scientific papers retrieved as described in Section 3.1 were distributed among the authors, who assessed their relevance for the scope of this paper, and classified them according to the steps of the workflow, introduced in Section 2.1, on which each study or part of study is focused:

Step1 Rule interpretation and digitalization of city and building regulations;

Step2 3D city models and useful related geoinformation preparation;

Step3 Pre-consultation and preliminary analysis (i.e., reading and analysis of the city and building data as references and constraints to the design; selection of the necessary information);

Step4 BIM and export to IFC (including IFC readiness and possible MVDs);

Step5 Application review (data quality check) - i.e., IFC validation;

Step6 Conversion to and integration with 3D city model or geoinformation;

Step7 Application review (content) - i.e., regulations checks and reporting;

\footnotetext{
${ }^{18}$ https://3d.bk.tudelft.nl/projects/eunet4dbp/events.html\#i-eunet4dbp-international-workshop-on-digital-buildin g-permit
} 
Step 8 Completion of the works and building authorities notification (delivery of as-built BIM and further information useful for following building and city life).

This classification will allow building an overview of the current progress related to each step of the workflow, which is useful to detect research and development gaps.

Second, tags about the ambitions and DBP requirements addressed in each work were added, according to the definitions of the EUnet4DBP (Section 2.3). The original EUnet4DBP ambitions and related DBP requirements were discussed by the authors within the context of this paper. It was an opportunity to rephrase them more clearly and removing residual ambiguity. The resulting list is reported and explained in Table 1 and Table 2.

\begin{tabular}{|c|c|c|c|}
\hline Pillar & N. & Sub-ambition & Examples \\
\hline \multirow{3}{*}{$\begin{array}{l}\text { Interoperable } \\
\text { Technology }\end{array}$} & T1 & $\begin{array}{l}\text { Interoperable scalable systems useful at } \\
\text { different levels (European, national, } \\
\text { municipality) and in different Countries }\end{array}$ & $\begin{array}{l}\text { Software (platform, analysis software, etc) can be adapted to many different contexts } \\
\text { (small / big municipalities, National / regional governments, etc.); Use of IFC to support } \\
\text { similar approaches in many countries and contexts }\end{array}$ \\
\hline & T2 & $\begin{array}{c}\text { Platforms allowing a data-centric } \\
\text { approach across the whole facility life- } \\
\text { cycle by means of a central management } \\
\text { of accesses }\end{array}$ & Common Data Environments covering seamless information flows \\
\hline & T3 & $\begin{array}{l}\text { Technologies for data visualization, data } \\
\text { analysis and data manipulation }\end{array}$ & $\begin{array}{l}\text { Model checkers, analysers and viewers considering the building model itself and/or its } \\
\text { city or landscape context (e.g., energy analysis, clash detection, urbanistic rules } \\
\text { checking, codes checking, shadow analysis etc.); Use of IFC to make analysis; } \\
\text { Conversion and integration algorithms }\end{array}$ \\
\hline \multirow{2}{*}{$\begin{array}{l}\text { Simple and machine- } \\
\text { readable rules and } \\
\text { requirements }\end{array}$} & R1 & $\begin{array}{c}\text { Unambiguous regulations interpretable as } \\
\text { computational parameters, algorithms, } \\
\text { clear constraints and criteria. }\end{array}$ & $\begin{array}{l}\text { Work intended to interpret the regulations as algorithms (collaboration with expert } \\
\text { checkers in municipalities; parameters in spreadsheet; programming or pseudo- } \\
\text { programming languages for storing regulations, etc.) }\end{array}$ \\
\hline & $\mathbf{R 2}$ & Explicit specification of data requirements & $\begin{array}{l}\text { Guidelines, standard data models, MVDs, shared vocabularies, etc. defining: objects } \\
\text { required, kind of geometry to be used, correct use of semantics, georeferencing, level } \\
\text { of abstraction and so on. They are consequence of combined regulation and } \\
\text { implementation requirements. }\end{array}$ \\
\hline \multirow{2}{*}{ Efficiency of process } & P1 & $\begin{array}{l}\text { Simplify the building permit process as } \\
\text { much as possible }\end{array}$ & $\begin{array}{l}\text { Remove possible unnecessary steps deriving from old-fashioned practice and limit } \\
\text { process to the fewest clear steps }\end{array}$ \\
\hline & P2 & Align the process at EU level & Many national administrations use the same process (and potentially the related tools) \\
\hline $\begin{array}{l}\text { Empowerment of public } \\
\text { officers }\end{array}$ & E1 & Mindset change of public officers & Direct involvement of public officers in the process of digitalization \\
\hline
\end{tabular}

Table 1: Re-phrased ambitions of the EUnet4DBP.

\begin{tabular}{|l|l|}
\hline N. & Requirement \\
\hline r1 & Digitalize the mindset of public officers. \\
\hline r2 & A roadmap and a change framework towards a fully DBP process. \\
\hline r3 & Normative text should be interpretable. \\
\hline r4 & Machine readable building codes. \\
\hline r5 & $\begin{array}{l}\text { Several kinds of data can be involved in the process (GIS, BIM, etc), with related clear information } \\
\text { requirements. }\end{array}$ \\
\hline r6 & Understanding the necessary process steps \\
\hline r7 & Alignment across Europe and beyond in Scope and Ambition \\
\hline r8 & Standardization \\
\hline r9 & Common Dictionaries \\
\hline r10 & Modelling conventions and guidelines \\
\hline r11 & Interoperability and APIs \\
\hline
\end{tabular}

Table 2: Re-phrased requirements of the EUnet4DBP.

Such tags will allow discussing a different kind of gap, related to the single ambitions and requirements, which 
could be in some cases more typical of some step, but they are often transversal throughout the whole workflow.

Moreover, kind of contribution, level of progress, and country have been used also as coding tags. The authors noted the kind of contribution according to the following classification:

\section{A Research}

A1) Literature review, evaluation of software or procedure and data review;

A2) Solid research or application experiment report, possibly supported by data;

B1) Demonstrator or early-stage experiments, preliminary to tools implementation, including studies implemented in a proof of concepts;

B2) Tools tested with many data, potentially usable/used in practice;

C Initiatives in operational environments - Inclusive and comprehensive works, likely applied within working environments.

Finally, the authors assessed the level of progress of each contribution according to the discipline of Project Management [68]:

1 Conception and Initiation;

2 Definition and Planning;

3 Executing;

4 Validating;

5 Closing.

Within such a work, the risk of bias in assigning the classification was very high, due to personal field of expertise and interests and subjective judgement or interpretations. Therefore, in order to limit such a risk, after a first screening and review round in which all the papers retrieved from the scientific databases were distributed equally among the authors, we redistributed the ones judged relevant for the DBP use case for going through a second round of review, by someone having different background than the first reviewer. This step was very useful for pointing out all the relevant aspects of the papers, since people with different backgrounds can often appreciate different faces of the same work. 


\subsection{Interpretation of results}

As a last step in our methodology, we tried to draw up relevant points by interpreting and summarizing the analyzed works. Again, we used both a quantitative method, by making graphs of the obtained results and a more qualitative summary of the contents of the papers related to each step. Due to the high level of interdisciplinarity of the topic, we could have great advantage by the multidisciplinary composition of the authoring team of this paper in assessing the completeness and internal consistency of such a complex and multi-faceted overview.

\section{Results}

\subsection{The bibliometric review}

In total, we considered relevant for our classification 111 papers and works. Figure 4 illustrates the number of contributions by year that are considered in this study. It can be seen from this figure that although there were at most five contributions until 2013, last seven years except 2017 have at least 10 contributions. Figure 4 thus shows the ever-increasing interest for DBP.

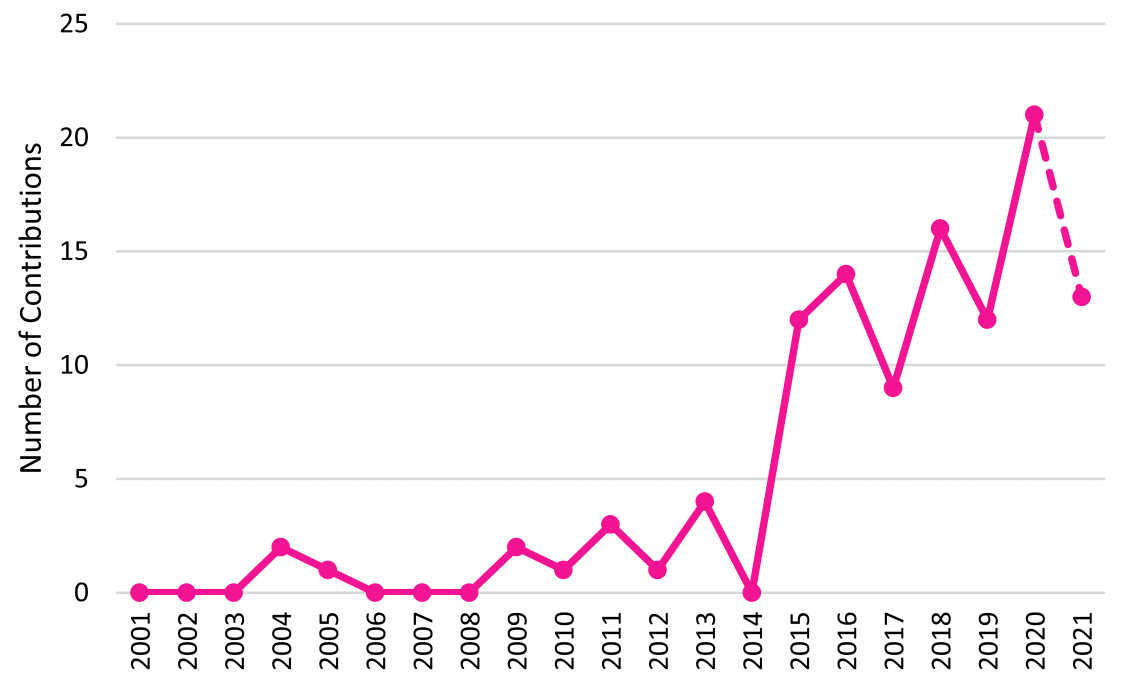

Figure 4: Distribution per year of the efforts. (Note: Papers published by February 3rd are included for 2021.)

Bibliometric analysis is an important source to represent the current state-of-the-art in the context of digitalization of building permit. For example, the keyword co-occurrences can show an insight into focused issues and approaches. There are several open-source tools that allow to visualize results of bibliometric search. In this study, VOSviewer ${ }^{19}$ is used to analyze and represent keyword co-occurrences. The visualizations in the VOSviewer are created using a Research Information Systems (RIS) file that is exported from a Mendeley ${ }^{20}$ folder that contains bibliometric details of the scientific papers. The keywords that appear at least twice in previous papers are used to obtain a connected network (Figure 5). There are 7 clusters in this network. Cluster

\footnotetext{
${ }^{19}$ https : //www . vosviewer. com/

${ }^{20}$ https : //WwW.mendeley.com/reference-management/reference-manager/
} 
365 language (VPL) in code compliance checking.

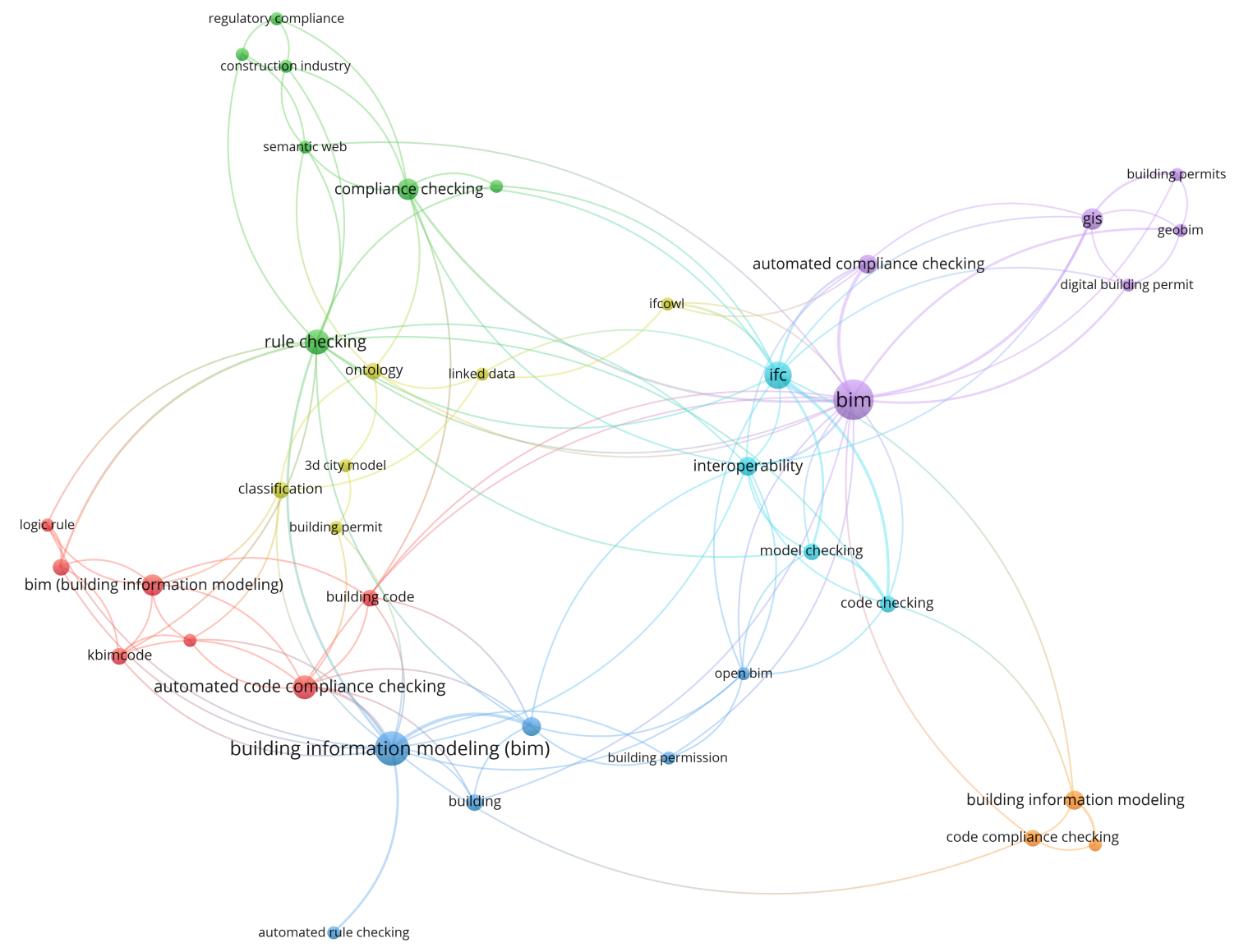

Figure 5: Co-occurrences of keywords that are used at least 2 times.

Figure 6 presents that there is an interest in automated building code checking for digital building permit by exploiting BIM in recent years. It can be also seen that the 3D city models and consequently GeoBIM for building permit are emerged more recently.

Table 3 shows that the state of the art regarding DBP focuses on the automatic code compliance checking by means of GIS and BIM, particularly the BIM open standard IFC. The co-occurrences of the words in the titles and/or abstracts of the papers are another option to show the trends pertaining to digitalization of building permitting. 


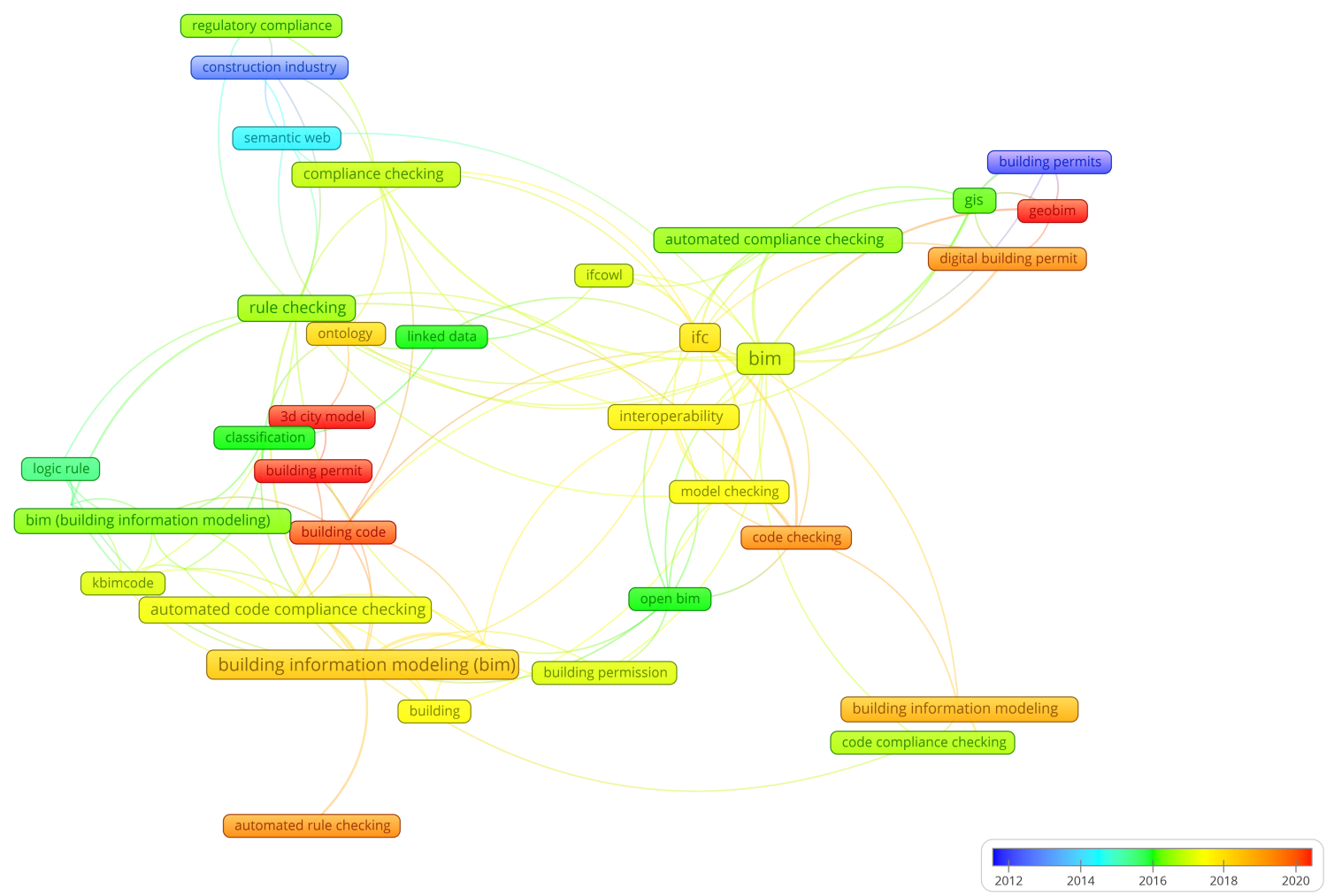

Figure 6: Temporal visualization of the keywords that are used at least 2 times.

\begin{tabular}{|l|l|l|}
\hline Keyword & Occurrences & Total Link Strengths \\
\hline building information modeling (bim) & 30 & 55 \\
\hline industry foundation classes (ifc) & 12 & 33 \\
\hline rule checking & 7 & 16 \\
\hline interoperability & 4 & 12 \\
\hline automated code compliance checking & 6 & 11 \\
\hline compliance checking & 5 & 10 \\
\hline gis & 5 & 10 \\
\hline code checking & 3 & 10 \\
\hline
\end{tabular}

Table 3: Occurrences and total link strengths of keywords in Figure 5.

As can be thus seen in Figure 7, the word rule is the dominant one regarding DBP. This is expected because the significant part of the DBP contains the ways of checking the building models against rules in the legislative documents. In addition, the words information, study, regulation, data, tool, and IFC are used in a large amount of papers. 


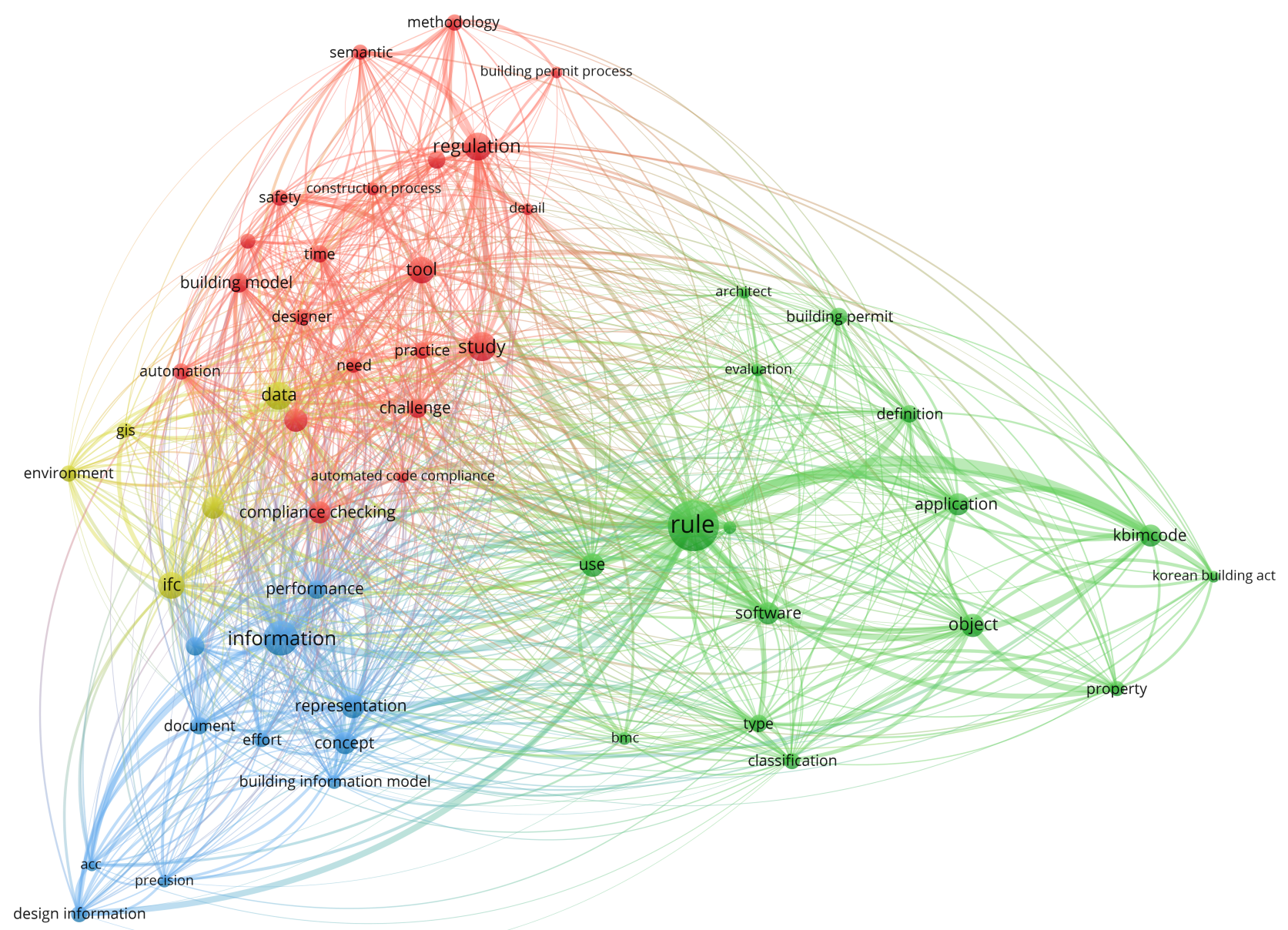

Figure 7: Co-occurrences of the words that are used at least 8 times in the titles and/or abstracts of the papers.

Table 4 itemizes the publication locations that have at least 5 contributions. It can be seen from this table that

Automation in Construction is the prominent journal followed by the Journal of Information Technology in Construction. Table 4 also shows that a notable number of contributions come from the proceedings of important organizations related to different fields of study such as civil engineering and geomatics engineering.

\begin{tabular}{|l|l|l|}
\hline Publication Location & Type & Number \\
\hline Automation in Construction & Journal & 10 \\
\hline $\begin{array}{l}\text { The International Association for Automation and } \\
\text { Robotics in Construction (ISARC) Proceedings }\end{array}$ & Conference & 10 \\
\hline $\begin{array}{l}\text { The American Society of Civil Engineers (ASCE) } \\
\text { Proceedings }\end{array}$ & Conference & 7 \\
\hline Journal of Information Technology in Construction & Journal & 5 \\
\hline $\begin{array}{l}\text { The International Society for Photogrammetry and } \\
\text { Remote Sensing (ISPRS) Proceedings }\end{array}$ & Conference & 5 \\
\hline
\end{tabular}

Table 4: Publication locations that have at least 5 contributions from 2001 to 2021

It is important to note that not all as relevant classified contributions are assignable to a certain step. In this case 8 papers were found. These are the following contributions: Plazza et al. [14], Ponnewitz and Bargstaedt 
[26], Messaoudi and Nawari [27], Messaoudi et al. [28], Ponnewitz [29], Noardo et al. [32], Noardo et al. [59], and Zhong et al. [69]. Contently, these contributions are integrated in the previous sections of this paper since they mainly consider the overall building permit process. They are not included in the further analysis.

\subsection{State of the art and highlights for each of the Steps of the reference workflow}

In this section, the main contents and relevant topics of the papers, classified according to each step of the DBP process, are summarised. Moreover, heatmaps depict the evolution of the investigation related to each step with respect to: kind of contribution, level of progress and publication years intervals. The description and full classification of each contribution is available in the Appendix A.

\subsubsection{Step 1: Rule interpretation and digitalization of city and building regulations}

This step is related to rule interpretation, the process of conversion of the natural language of city and building regulations into computable parameters and constraints for automating and digitalizing the building permitting process. Almost all studies (full list in Table A.5) aim at converting regulations to a machine-readable format to check the rules using IFC data of the buildings. For example, Noardo et al. [70] investigated the rule interpretation regarding building height, overhang and tower ratio in the context of Rotterdam Municipality in the Netherlands. CityGML-based data is also utilized to check compliance of the application against zoning plans [71]. The Requirement, Applicability, Selection, and Exception (RASE) methodology is used to code the building regulations for compliance checking by Beach and Rezgui [72], Nisbet et al. [73]. In addition, the hybrid approach that modifies the RASE methodology is proposed and exemplified by using Izmir Municipality Housing and Zoning Code in Turkey [74]. The Natural Language Processing (NLP) techniques are proposed to convert the rules in building regulations into a computer-readable format with the aim of automating the compliance checking $[75,76,77,78]$. Several studies focus on improving the classifications of KBimCode that is developed to store machine-readable regulations in South Korea [12, 79, 80, 81, 82, 83]. It is also highlighted how computerizing the building codes is a challenging task within the AEC industry [84].

Figure 8 shows that an advanced but isolated work was done in the years interval 2006-2010, but the investigation is developing more in the following years, and especially in the last five years, with many contribution to early stage implementations (B1), reaching the three most advanced levels of progress.

\begin{tabular}{|c|c|c|c|c|c|c|c|c|c|c|c|c|c|c|c|c|c|c|c|}
\hline Closing & & & & & & & & & & & & & & & & 1 & 3 & & \\
\hline Validating & & & & & & & & 1 & & & & & & & & & 1 & & \\
\hline Executing & & & & & & & & & & & 1 & 1 & & & & 1 & 6 & & \\
\hline \multirow{4}{*}{$\begin{array}{l}\text { Definition and Plannıng } \\
\text { Conception and Initiation }\end{array}$} & & & & & & & & & & & & & & & & & & & \\
\hline & & & & & & & & & & 1 & & & & & & & & & \\
\hline & A1 & A2 & B1 & B2 C & A & $1 \mathrm{~A} 2$ & B1 & B2 & C & A1 $A$ & $\mathrm{~A} 2 \mathrm{~B}$ & B1 & B2 $\mathrm{C}$ & $C$ & A1 & $\mathrm{A} 2$ & B1 & B2 & C \\
\hline & & 2001 & $1-20$ & 005 & & & $06-2$ & 2010 & & & 2011 & $1-2$ & 015 & & & 201 & & 021 & \\
\hline
\end{tabular}

Figure 8: Heatmap showing the evolution of implementation and progress through the years for Step 1. 


\subsubsection{Step 2: 3D city models and useful related geoinformation preparation}

Five works were found, detailing the use of geoinformation and 3D city models as input for building permitting (Table A.6). Among the available standards, reviewed by Guler and Yomralioglu [34], the most considered Open data model for representing geoinformation and 3D city models as a base for the automatic analysis to check the regulations (mainly zoning and urbanistic rules) is CityGML, which is extended and adapted to the national standards in some cases, such as by Eriksson et al. [85]. In some works, the requirements of geoinformation are specified (e.g., [43]), which is a relevant step towards interoperability.

Other papers $[86,87,88]$ deal with the conversions of $3 \mathrm{D}$ city models to BIM, either considering the respective standards CityGML and IFC or more general national or proprietary widely used formats. Conversion is an essential step for allowing the designers to consider geoinformation as a suitable reference.

Besides the studies listed in Table A.6, other pilots are being implemented in which the geoinformation component plays a very relevant role and will likely publish their solutions in the next future, such as in the State of Geneva and Dubai [66].

In Figure 9, it is visible how an initial experiment was done almost twenty years ago, but most of the evolution had place in the last years, in an intermediate level of implementation between research and early-stage implementations and overall reaching and intermediate progress.

\begin{tabular}{|c|c|c|c|c|c|c|c|c|c|c|c|c|c|c|c|c|}
\hline \multicolumn{17}{|l|}{ Closing } \\
\hline Validating & & & & & & & & & & & & & & 1 & 1 & \\
\hline Executing & & & & & & & & & & & & & & 144 & 4 & \\
\hline Definition and Planning & & & & 1 & & & & & & & & & & 1 & & \\
\hline \multirow[t]{3}{*}{ Conception and Initiation } & & & & & & & & & & & & & & 1 & 1 & \\
\hline & \begin{tabular}{|lll} 
A1 & A2 \\
\end{tabular} & 2 B1 & B2 & \begin{tabular}{l|l} 
C & . \\
\end{tabular} & $\begin{array}{lll}\text { A } 1 & \text { A2 } \\
\end{array}$ & B1 & B2 C & & \begin{tabular}{l|l}
41 & $A 2$ \\
\end{tabular} & 2 B1 & B2 C & \begin{tabular}{l|l}
$C$ & $A$ \\
\end{tabular} & $\begin{array}{lll}A 1 & A\end{array}$ & $\begin{array}{lll}2 & \text { B1 } \\
\end{array}$ & 1 B2 & C \\
\hline & 20 & $01-20$ & 005 & & 200 & $06-20$ & 010 & & & $11-2$ & 2015 & & & $016-2$ & -2021 & \\
\hline
\end{tabular}

Figure 9: Heatmap showing the evolution of implementation and progress through the years for Step 2.

\subsubsection{Step 3: Pre-consultation and preliminary analysis}

Step 3 (Table A.7) describes pre-consultation and preliminary analysis in advance of the submission of a building permit application which is proceeded by the applicant together with the authority. In some cases either the applicant or the authority is in charge of the preliminary analysis. This steps includes, among others, reading and analysis of the city and building data as reference and constrain to the design as well as selection of the necessary information. In conclusion, Step 3 papers consider early design stage approaches regarding the analysis of building codes [71, 89, 90, 91, 91, 92] and the development of frameworks [93, 94]. Within the review process, eleven papers were classified as a Step 3 contribution. Among these, three are contributions from the practical field $[73,95,96]$. The practical approaches focus on tool assistance of the early design phase and design check.

Step 3 started being investigated from a fifteen years ago, but became mostly interesting in the last five years, 
as most of the other steps (Figure 10). The progress reached by the different contributions is various.

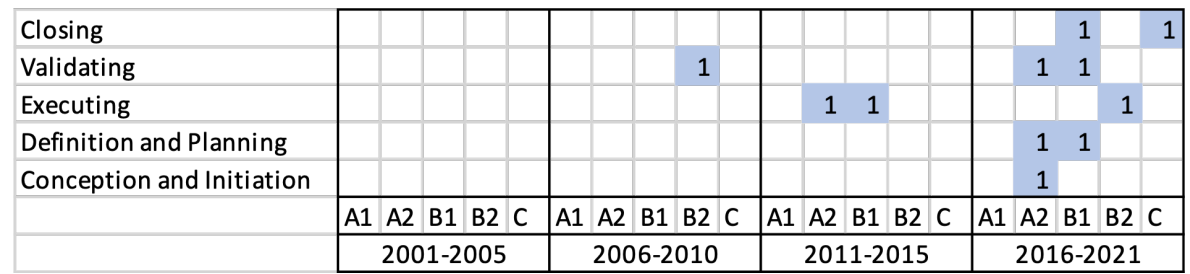

Figure 10: Heatmap showing the evolution of implementation and progress through the years for Step 3.

\subsubsection{Step 4: Building information modelling and export to IFC}

Figure 11: Heatmap showing the evolution of implementation and progress through the years for Step 4.

\subsubsection{Step 5: Application reviewed (data quality check)}

Step 5 describes the implementation of the "validation checking" concept as described in Hjelseth [5]. Validation checking (e.g., BIM/IFC validation) validates the informative content of BIM models and checks if they 
embed the data set required. Therefore, it ensures quality and internal consistency of a BIM model, which is and interoperable workflow. On the other hand, in some cases research works could reach a high level of implementation (B2) and progress (Figure 12).

\begin{tabular}{|c|c|c|c|c|c|c|c|c|c|c|c|c|c|c|c|}
\hline Closing & & & & & & & & & & & & & 1 & & \\
\hline Validating & & & & & & & & & & & & & 1 & 1 & \\
\hline Executing & & & & & & & & & & & & & 12 & & \\
\hline Definition and Planning & & & & & & & & & & & & & & 1 & \\
\hline \multirow{3}{*}{ Conception and Initiation } & & & & & & & & & & & & & 2 & & \\
\hline & $\mathrm{A} 1 \mathrm{~A} 2$ & B1 & B2 C & $A$ & $A 2$ & B1 & B2 & $\mathrm{C}$ & A1 $A^{-}$ & $\mathrm{A} 2 \mathrm{~B} 1$ & B2 C & A1 $\mathrm{A} 2$ & 2 B1 & B2 & C \\
\hline & 20 & $01-20$ & 005 & & 200 & $06-20$ & 010 & & & $011-2$ & 015 & & $16-20$ & 021 & \\
\hline
\end{tabular}

Figure 12: Heatmap showing the evolution of implementation and progress through the years for Step 5.

\subsubsection{Step 6: Conversion to and integration with 3D city model or geoinformation}

This step concerns the conversion of BIM data to geoinformation and integration with a 3D city model which is a research topic that has attracted increasing interest in the recent years and is often referred to as GeoBIM

\footnotetext{
${ }^{21}$ https://www.solibri.com/
} 
(See 2.2.3). In the building permit workflow the integration is performed to place the (planned) designed building (BIM) in context (GIS). The step is crucial for checking regulations that require information about the surroundings of the planned building and it enables analysis of how the planned building will influence already existing buildings in the area. Seven publications were related to this step with three of them being scientific contributions [85, 87, 114], one report [105], one presentation from the Eunet4DBP workshop [115] and two web resources describing pilot studies $[116,117]$. In most studies, IFC models were converted to CityGML (incl. national ADEs), and the most common tool for performing the conversion was the extract, transform, and load tool Feature Manipulation Engine (FME) from SAFE Software ${ }^{22}$.

It is also important to note that in addition to integrating BIM data and geoinformation to check that a planned building conforms to the regulations before the building permit is approved, the methods described under Step 3 were also applied to update an existing 3D city model with an as-built BIM model delivered in Step 8 of the workflow.

As for Step 5, also for Step 6 the contributions were developed only in the last five years and reach an intermediate level of progress for early-stage implementations and a case of application in operational environment (Figure 13).

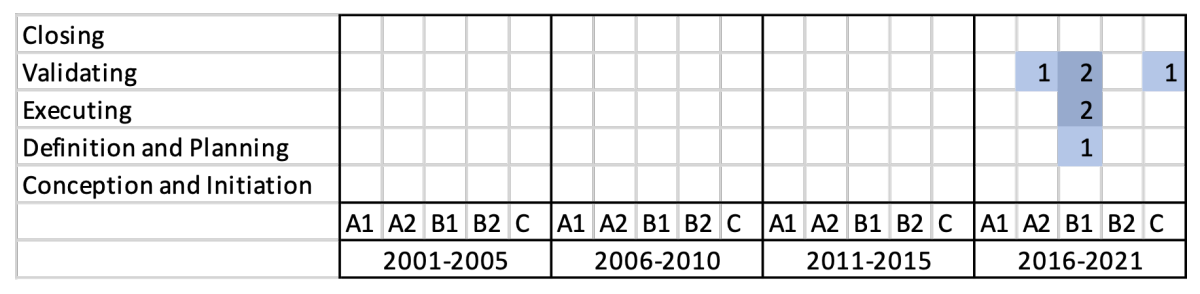

Figure 13: Heatmap showing the evolution of implementation and progress through the years for Step 6.

\subsubsection{Step 7: Application review (content) - i.e., regulations checks and reporting}

This step is related to the automatic checking of the content in a BIM model for a specific use. In building permitting, this means that the BIM model has to be examined against specific requirements defined in Codes and Regulations (i.e., Building Code, Urban Plan, Fire Code, Health and Safety code, etc.) to obtain a building permit approval.

As, along the design and construction process, there are many Codes and Regulations to be in compliance with, there are multiples uses for checking BIM models as well. Many studies focus on developing tools and prototypes for checking Urban Plan, in a GeoBIM perspective. These studies are localized mainly in The Netherlands $[70,71,118]$ and in Sweden $[85,105,114,119]$, while, at commercial level, Spain stands out with the development of the tool Cype Urban [120]. In South Korea, a BIM-based e-submission and automated code compliance checking system for building permitting (KBIM) has been developed with the support of the

\footnotetext{
${ }^{22}$ https://www.safe.com/
} 
Ministry of Land, Infrastructure, and Transport [33, 90, 121]. Other studies intend to prototype applications for specific uses without considering country-related constraints. In these cases, the code checking uses are for: energy performance evaluations [122], acoustic performance checking [123] and sustainability regulations [124], fire codes [91, 125, 126], deep foundation construction [127], spatial program [128] and building code $[6,93,102,129]$ compliance.

As stated by Hjelseth [130], the main challenges in achieving a BIM-based code compliance checking are: the complexity of Codes and the impracticability of existing automated checking approaches. The key problems are: rules interpretation, semantic matching of requirements in Codes and in BIM models and the standardization of information requirements [127].

Commercial software are not supportive in overcoming these challenges since their functionalities are based on the use of simple rules and unspecified content of information in the BIM model [5]. For this reason, almost all studies and experiences in Table A.11 focus on developing bespoke prototypes and tools rather than on improving existing commercial solutions: only few studies [91, 93] develop a code checking system based on Autodesk Revit and its VPL tool Dynamo ${ }^{23}$, while $[71,108,131]$ are based on SMC. All the other studies find their fondants in developing open-source and open-format solutions.

In particular, almost all the research are based on the use of open standards, i.e., IFC and CityGML, for model representation. Focusing on the use of IFC, the data contained into the file have to be extracted in order to further being represented in a semantic-based logic and matched with regulatory information. To do that, most of the studies focus on converting information extracted from the BIM model into ontology instances, ready to be automatically checked against logic-represented regulatory rules using NLP techniques [106], Java environment [132] and SPARQL Protocol and RDF Query Language [133]. NLP techniques are used also to read and transform requirements of Codes into machine readable rules [77, 123, 134]. Other very common techniques are: VPL, used by [113] and [121], and Visual Code Checking Language [135].

At the end of the content review process, the reporting of checking results should include information about all the checking performed with relevant codes listed for reference. Results are displayed in a table format or in a PDF format, which should include the list of checks performed, engineering parameters (extracted from model), the name of checking rules, the corresponding code articles, and checking conclusions [127].

Step 7 is where most of research and literature has focused, with relevant effort from more than ten years ago. We can see from Figure 14 that often an intermediate-to-high level of progress is reached, although limited to research and early-stages implementations (B1) until five years ago. In the last years, also the implementation level has raised and there are already some examples of B2 works at a level executing, plus two cases of application in operational environment, one of them at progress 'Closing'.

\footnotetext{
${ }^{23}$ https : //dynamobim.org/
} 


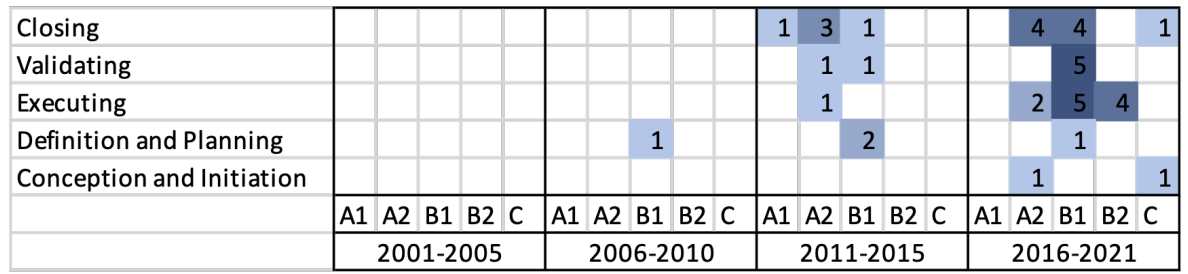

Figure 14: Heatmap showing the evolution of implementation and progress through the years for Step 7.

\subsubsection{Step 8: Completion of the works and building authorities notification (delivery of as-built BIM} and further information useful for following building and city life)

This step includes the completion of the works done previously as well as notification issues. After the application has been reviewed in terms of content, the responsible building authority must transfer a formal notification, often accompanied by notification of charges. In order to execute this part of the process in an aligned legal framework, building codes and potentially general administrative law need to be adapted. For example the building code of the state of Lower Saxony (Germany) [136] requires written form and is currently in progress towards a DBP paperless process. With respect to the use of mature building application platforms, not only communication between building authorities and applicants during the application process but also final notifications to complete these administrative acts are supposed to be an integrated module in alignment with the underlying law. Furthermore, the use of existing digital data, e.g., for CAFM or further city planning, are part of Step 8. Two publications were related to Step 8. Chognard et al. [87] describe a DBP procedure for a Swiss municipality. City of Sant Feliu [137] describes a development towards a smart city, offering public online services including participation in city planning.

The two contributions about Step 8 were developed in the last five years and are early-stage implementations, at intermediate-high level of progress (Figure 15).

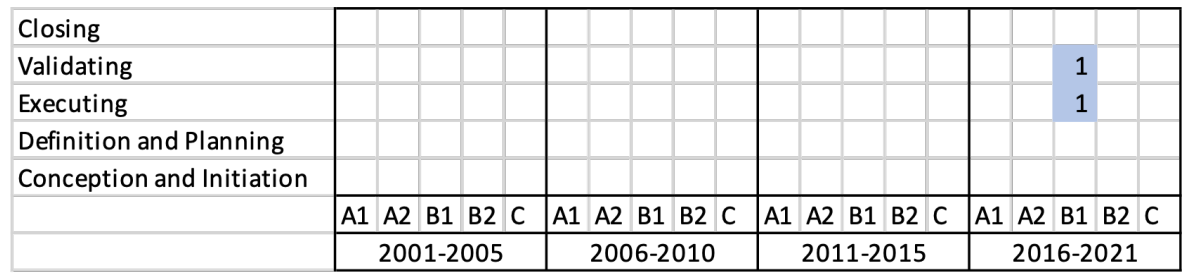

Figure 15: Heatmap showing the evolution of implementation and progress through the years for Step 8.

\subsection{Excluded but related papers}

We included in the review only the documents directly relevant to the scope of building permits digitalization, therefore, some other studies that contain relevant contents, but are originally intended for other use cases were excluded. However, for the sake of completeness, we report here some of those papers, which were selected by the algorithms in the bibliometric search and were assessed by the authors as somehow relevant although not directly related to the building permits themselves. 
Soliman-Junior et al. [138] discusses available commercial tools (dRofus and SMC) to assist in the data requirements management and check during the design phase, in order to improve the final design quality. Zhang and Beetz [139] extend SPARQL to query IFC-models for code compliance checking in a linked data environment and implements a prototype for a case study. Zhang and El-Gohary [140] propose a method to extend the IFC-schema to facilitate automatic code compliance checking by matching concepts in regulations with concepts in IFC and classify relationships with machine learning methods. Fan et al. [141] creates a framework for rule checking of BIM models with the focus on a user-friendly and flexible interface that enables a designer to include the rules valid for the model to check via a visual programming interface. Métral et al. [142] presents a model based on ontologies for compliance check of rules related to subsurface objects in 3D city models. Lee et al. [143] presents a method for automated rule checking of BIM models that also guides the designer in the design process by automatically suggesting changes to comply to the rules. Guedes et al. [144] suggests to develop BIM information modeling guidelines to ensure that the necessary information are included in the IFC model to facilitate automated code checking. The study is focusing on airport design. Qi et al. [145] proposes the use of the Solibry Model Checker to check the rules related to the workers' safety. Trebbi et al. [146] considers available tools to be used for the checks. Dimyadi et al. [147] demonstrates how a subset of the New Zealand Building Code can be encoded into a computer executable format with the open standard Business Process Model and Notation. Kim et al. [148] presents a method, based on visual language programming, to translate natural language into computer executable code. Evans and Counsell [149] develops course design in architecture school that contains the BIM-based automated code checking using SMC to enhance the ability and awareness of the students. Mena et al. [150] proposes a new XML-based standard that facilitates the project information flow required for different phases, including building permit, in the life cycle of buildings. Nawari and Alsaffar [151] seeks to examine the role of BIM in improving the permitting procedure and proposes a framework for simplifying the permitting procedure for residential housing with a focus on architectural and structural design. Choi et al. [152] proposes an approach that allows to extract required information from IFC data by adding extra attributes in Revit to assess building design in terms of energy performance. Fahad and Bus [153] investigates the geolocation-based relationships of the objects (e.g., fire fighting device) in the IFC file using Well-Known Text (WKT) and graph databases, namely Stardog and GraphDB, for compliance checking. Belliard [154] examines the use of BIM in plan review process within building permitting to support traditional 2D approach by surveying with local architects. Strobbe et al. [155], Shi and Roman [156], and De Vos et al. [157] consider assistance of the design phase according to building regulations prior to the submission of the building permit application. Zdravkovic and Ostman [158] deal with presenting GEOinfo in public services. Lee et al. [159] investigate data exchange standards. Karim et al. [160] examine the dissemination of spatial information in the case of Malaysia. 


\section{Discussion}

The classification of the reviewed contributions allowed the authors to draw the general picture about the available works for each step of the DBP process. Moreover, previous studies have been classified according to several aspects:

- their overall distribution among the DBP steps to highlight where previous research efforts have been concentrated to identify any gaps (Section 5.1 );

- reference country, to evaluate if a geographical leadership exists in DBP-related research activities (Section 5.2);

- kind of contribution and level of progress (Section 5.3);

- main EUnet4DBP ambitions and related requirements addressed (Section 5.4).

In the following subsections such results are represented and discussed.

\subsection{How much is each step investigated}

As visible in the distribution in Figure 16, the focus of science and other investigations in the last twenty years was mainly on Step 7, i.e., application review with respect to the compliance of the content of the model to building and city regulations. Indeed, the automation of checks is generally seen as the first condition to digitalize the building permitting process. In addition, the software available on the market to support this step (such as the one developed by companies like Solibri, CYPE, Xinaps, ACCA software, among others) are not all counted in this paper, but increases even more the effort directed at solving the regulations checking step.

Step 4, building model preparation, and Step 1, provision of digital regulations, clearly show how the use case was first investigated in the field of BIM, rather than in its connection to the geoinformation field.

Step 5, related mainly to BIM and IFC validation as a main step to allow interoperability between authoring plaftorms and checking tools, comes later, with a 10\% of contributions and starting only from 2015 (Figure 17), a few years after the IFC became an ISO standard in 2013.

Step 3 is probably less addressed because it is considered a minor issue with respect to other enabling phases of the digital workflow.

Finally, Step 2 and Step 6 deal with the connection between 3D city models and BIM and, more in general, with the use of $3 \mathrm{D}$ city models to check the regulations and support the DBP process. Besides one very early study from 2005 [43], the interests in those steps arises only from 2017. We expect it to grow in future (Figure 17). 
Finally, Step 8 was addressed earlier, but with an overall low effort, probably due to the higher priority of previous steps.

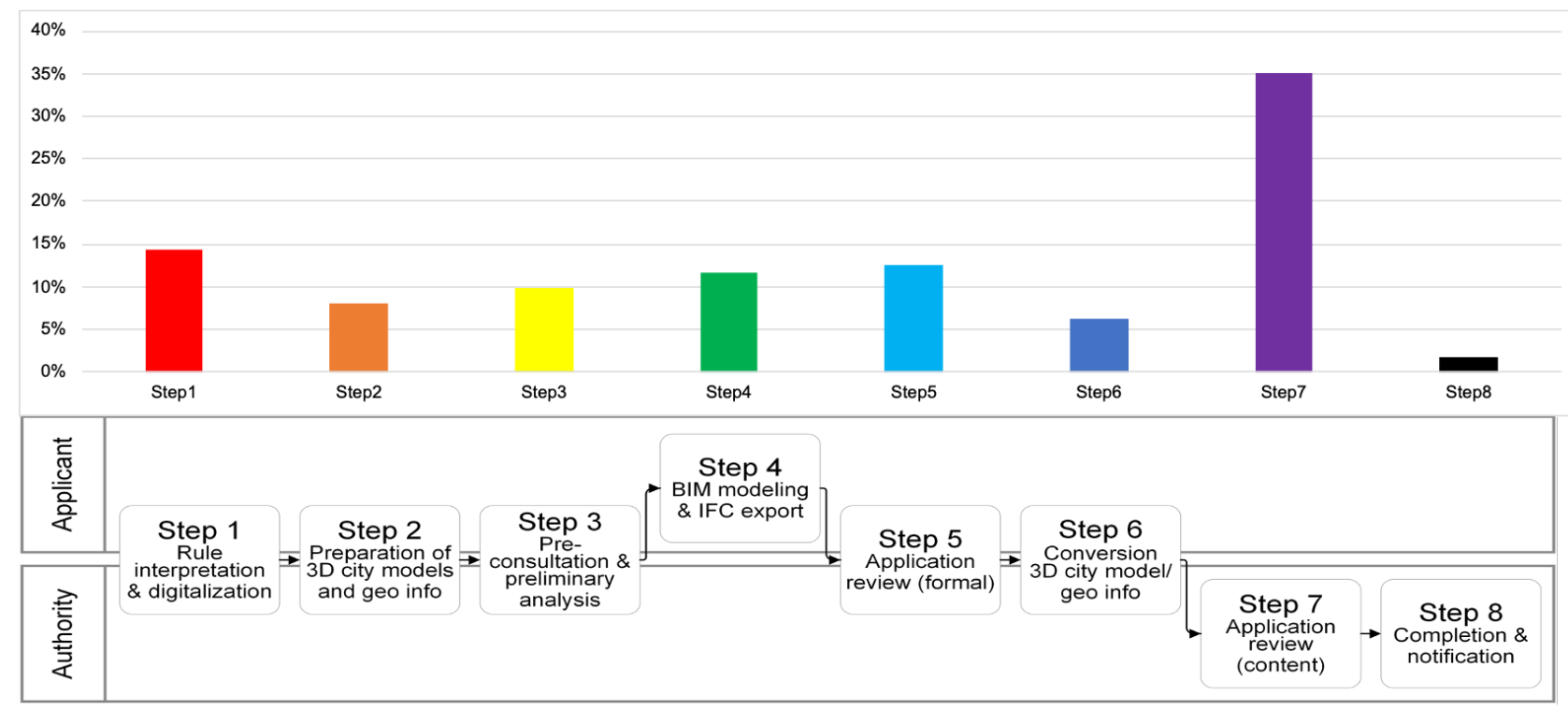

Figure 16: Histogram representing the contributions related to each step.

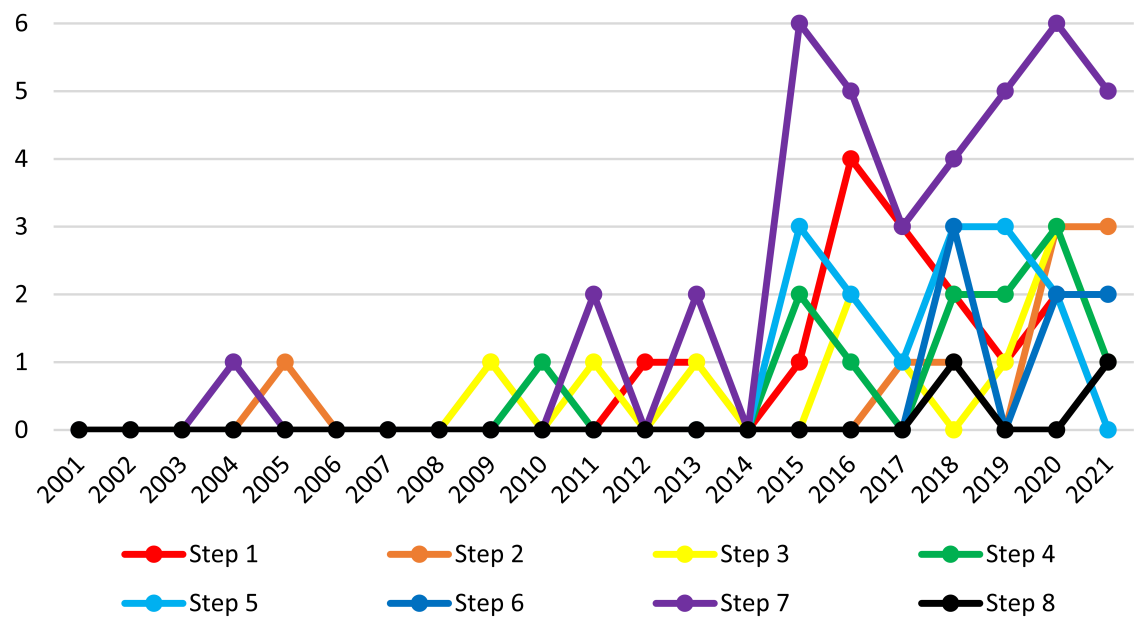

Figure 17: Distribution per year of the efforts related to each step.

\subsection{What countries are working on Digital Building Permit}

Figure 18 and Figure 19 show the distribution of research and development efforts for digitalizing the building permitting process globally with the largest number of contributions in North America and Europe. Some countries in Asia and Middle East, with South Korea as the second major actor in the world, have also produced a relevant number of works and studies on the topic.

Noteworthy to mention is that the number of works do not represent the level of developments of the countries regarding digitalization of building permit. For example, although Estonia and Norway have noteworthy 
experiences for the digital building permit, the reviewed items are not many.

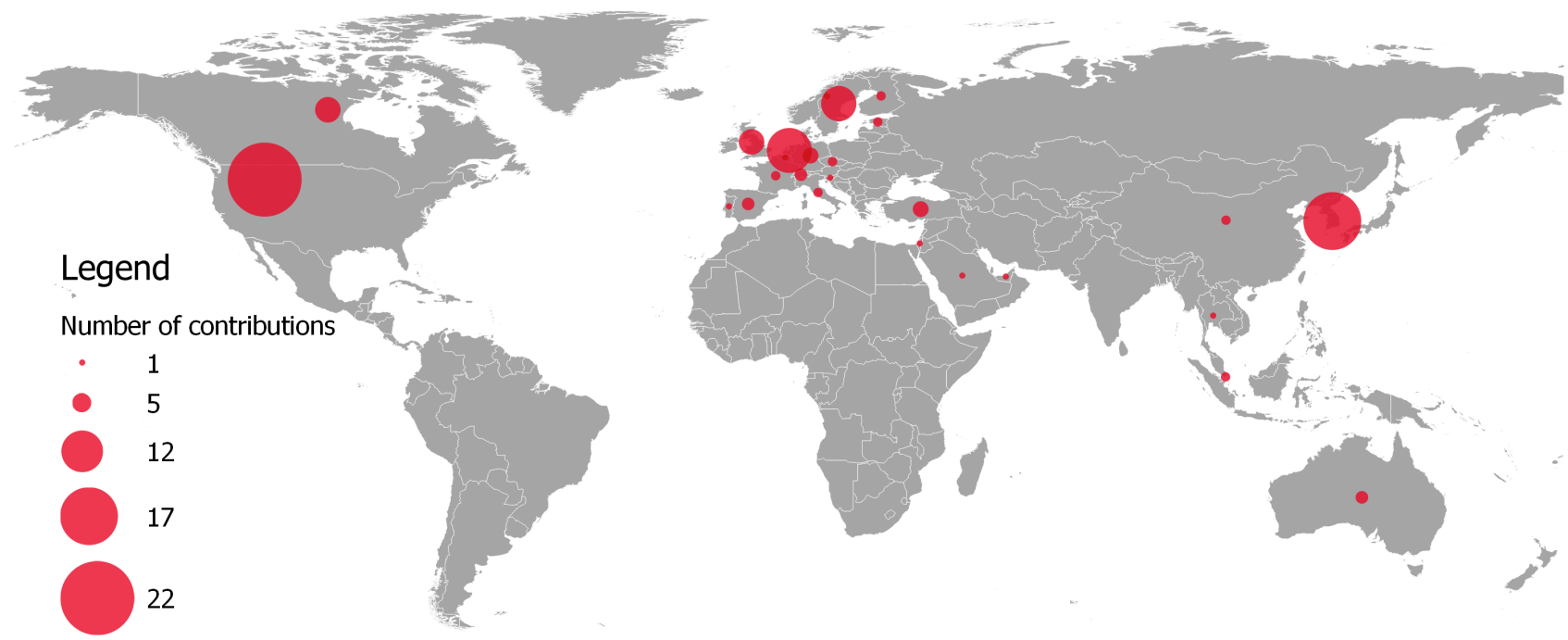

Figure 18: Map showing the provenance of the reviewed contributions.

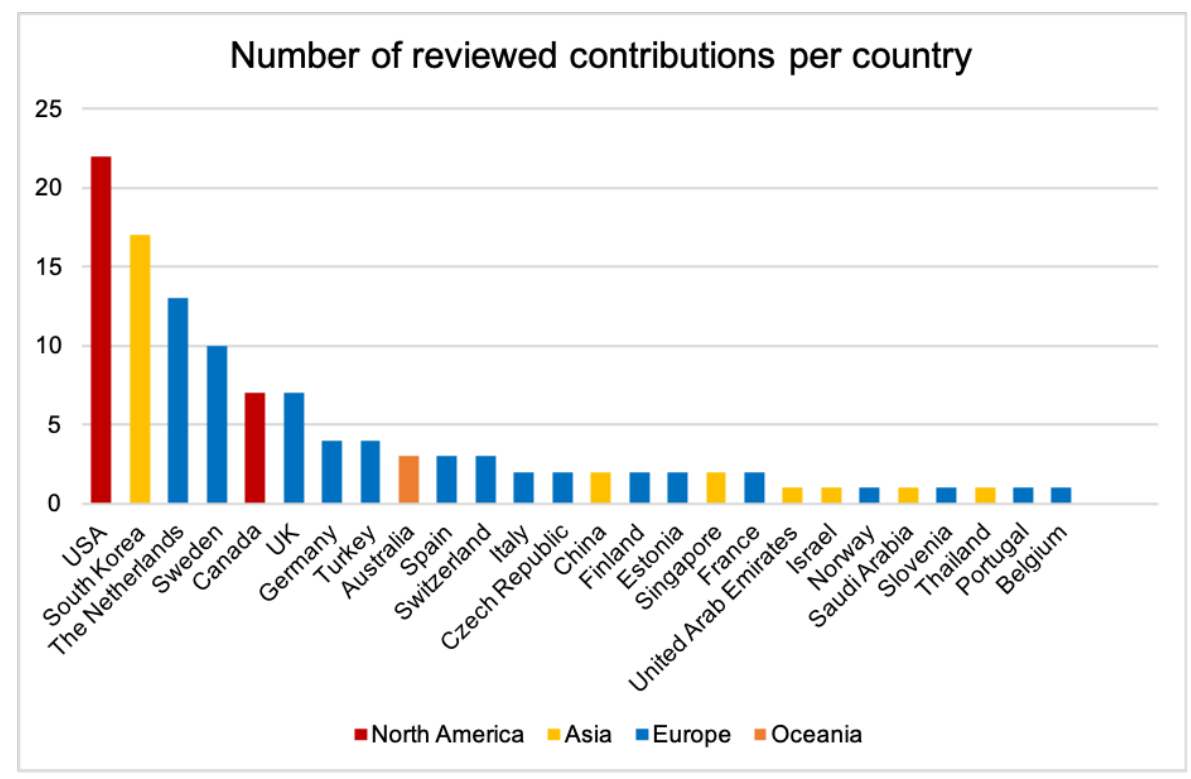

Figure 19: Number of reviewed contribution per country.

\subsection{What kind of contribution is being developed and what is the overall progress}

Figure 20 shows that the main kinds of contribution developed so far are in the category of base studies on the application (A2), most likely implemented within demonstrators and proof of concepts (B1).

Those two categories are aimed at addressing the most complex issues involved in the topic, which are often strictly related to specific cases, for which probably the A1 works are less frequent, and need to address basic research questions related to the application until demonstrating the theories in early implementations (B1). 
We can see that, at the moment, the early implementations seldom reach a higher maturity (B2). In the cases where a marketable software is produced, it is usually disconnected by research and not considered in this review.

Category C, which reports about initiatives in operational environments, follows.

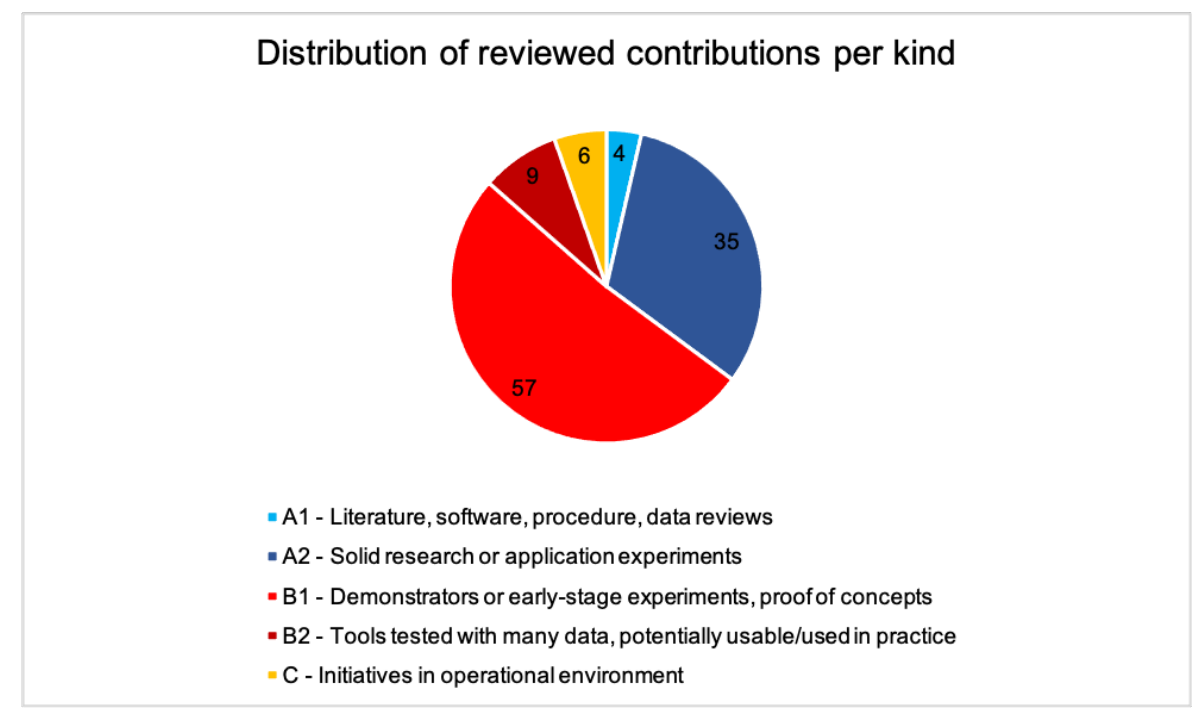

Figure 20: Pie chart showing the more addressed EUnet4DBP ambitions in each step.

Figure 21 offers an additional interesting insight into the distribution of items according to the kind of contribution throughout the steps.

Step 1 - digitalization of regulations - presents a rather consistent distribution of items per kind, passing through basic research and proof of concepts to go towards more mature implementations. No experiments are reported yet in operational environment, probably keeping those studies in the accademic world for the moment.

Step 2 - preparation of 3D city models as input - and Step 3 - pre-consultaion and preliminary analysis as well as Step 6 - GeoBIM conversions - have a similar distribution as Step 1, although no A1 items are reported, while there is an experiment in operational environment. It could also be an indication about how those three steps are related.

Step 4 - BIM modelling and IFC export - emerges in the graph in Figure 21 for counting mainly on A2 items, while the implementation is still weak. We could relate this also with other current research that investigates the IFC interoperability issues $[161,162]$. At the same time, Step 5 also contains references to the development of checking tools adopting several technologies. However, no applications (kind $\mathrm{C}$ items) are reported, meaning that a validation on the field could still be missing.

Step 7 - Content checking against regulations - counts on the higher effort both in terms of research and early implementations and in attempts in operational environment $(C)$. In this case the two aspects research 
and application are tackled in parallel.

We have only two items for Step 8 - Completion and notification - which are both in the early implementation (B1) category.

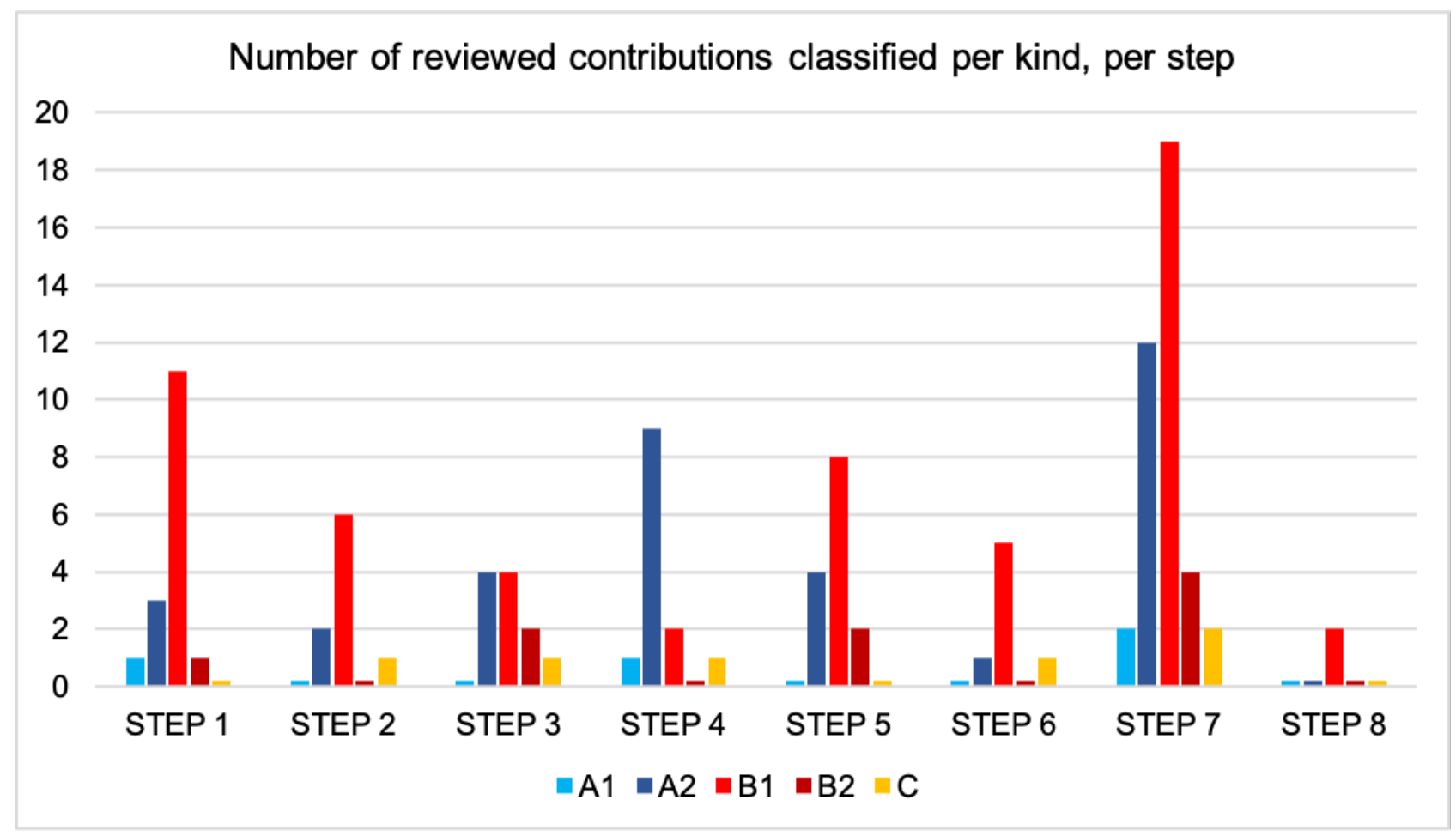

In Figure 22 we can see how most of the works are in an intermediate 'Executing' phase, even though many have also reached a higher progress, with only a 7 out of 111 in 'Conception and initiation' phase and 13 in 'Definition and planning'.

\section{Distribution of reviewed contributions per progress}

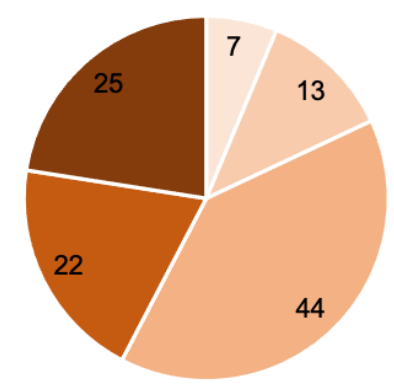

Conception and Initiation $\quad$ Definition and Planning $=$ Executing $=$ Validating $\quad$ Closing

Figure 22: Pie chart showing the more addressed EUnet4DBP ambitions in each step 
Figure 23 shows how some of the steps, such as Steps 2 and 4 are still mainly in 'Executing' level of progress, while, for the others, works are present in all the higher levels of progress.

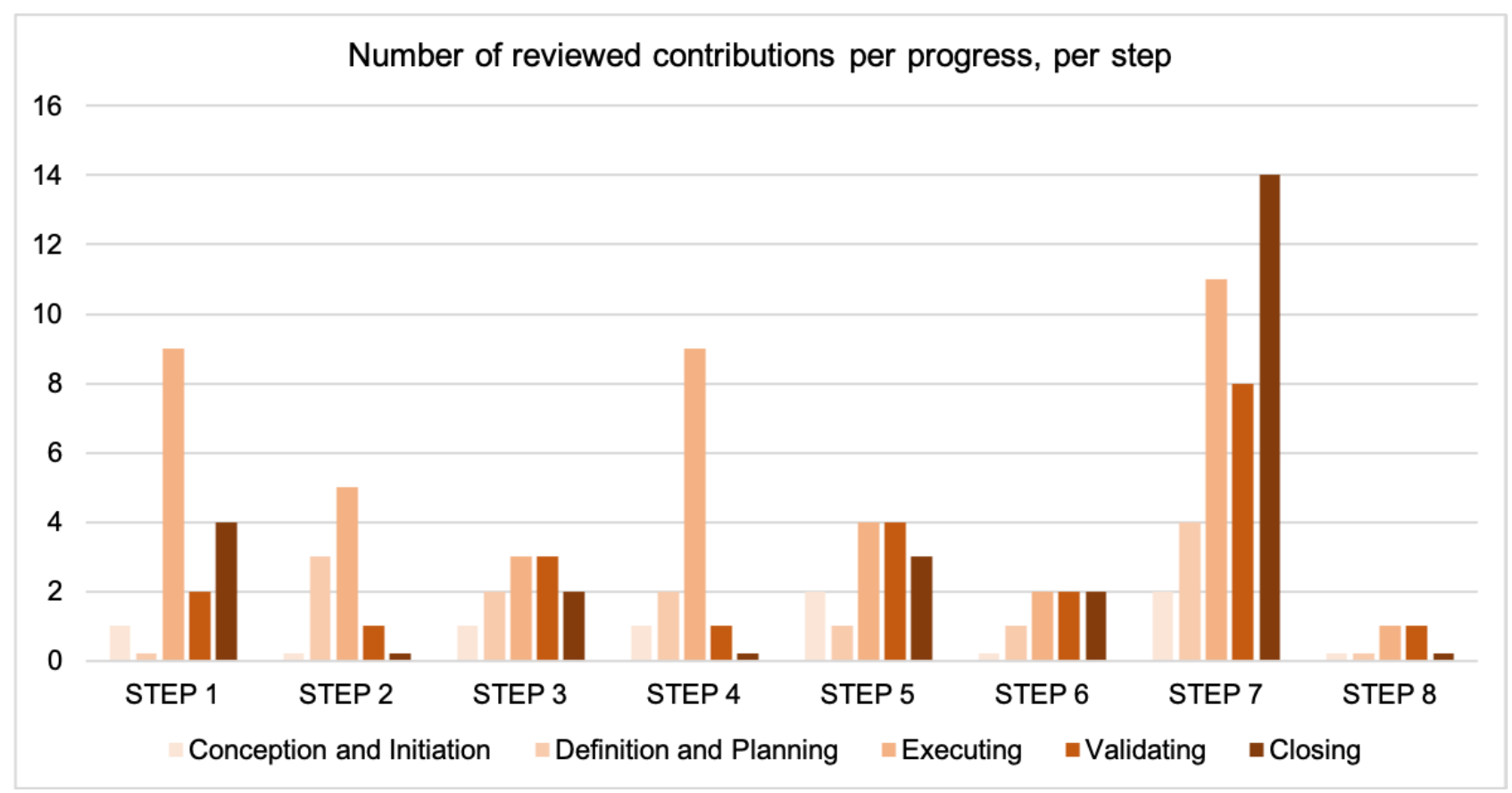

Figure 23: Hystogram showing the number of reviewed contributions per each level of progress in each step

\subsection{Which are the EUnet4DBP ambitions and related requirements addressed}

Figure 24 shows how the T3 ambition, i.e., 'Technologies for data visualization, data analysis and data manipulation', is the most addressed one, especially, but not limited to, by Step 7. This is unsurprising because the role of technology in regulation checking and reporting is evident.

The other ambitions related to the technology, T1 - 'Interoperable scalable systems useful at different levels

(European, national, municipality) and in different Countries' - and T2 - 'Platforms allowing a data-centric approach across the whole facility life-cycle by means of a central management of accesses' are instead less addressed. This might be because creating and operating the comprehensive system that enables the data flow for DBP is difficult since the various stakeholders and organizations get involved in the workflow. Some work is available for T2, especially related to Steps 2, about the provision of 3D city model and suitable geoinformation, and Step 3, about the pre-consultation phase. But in very few cases T1 is addressed.

The ambitions related to rules and requirements, R1 - 'Unambiguous regulations interpretable as computational parameters, algorithms, clear constraints and criteria' - and R2 - 'Explicit specification of data requirements' are similarly addressed mainly for the Step 1, about digitalization of regulations, and Step 7 about automation of regulations checks. Moreover, R2 is also significantly addressed for Step 4, about BIM and IFC preparation, which should be compliant to the established requirements. 
The ambitions about the process are slightly less addressed, especially P2 - 'Align the process at EU level' - is almost not addressed at all in the current state of the art. It is probably because of the differences in the countries' legislative documents regarding building permitting. P1 - 'Simplify the building permit process as much as possible' - is instead addressed again mainly by Step 4 and Step 7.

There are some cases in which the ambition E1 - 'Mindset change of public officers' - is addressed, but still in weaker terms than for the others.

Another interesting finding, shown in Figure 24 is how each step often addresses ambitions belonging to the different EUnet4DBP pillars process, rules and requirements and technology. It makes it clear how the three aspects need to be considered in all the parts of the workflow.

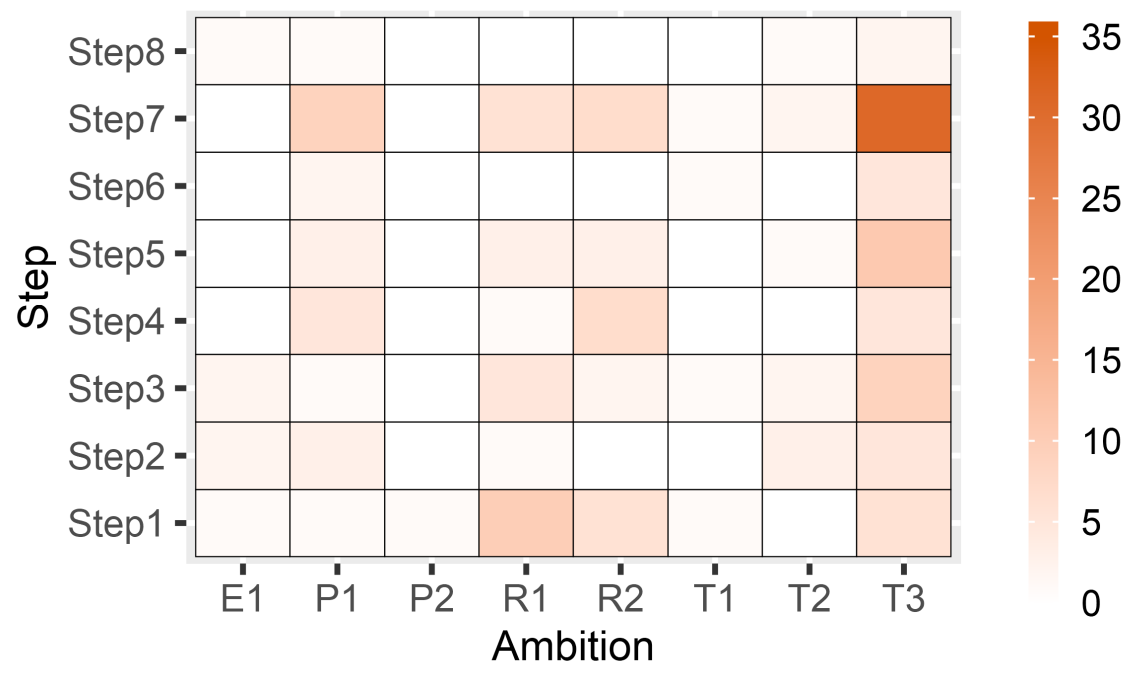

Figure 24: Heatmap showing the more addressed EUnet4DBP ambitions in each step.

The most addressed requirements (Figure 25) are r4 - 'Machine readable building codes', especially in association to Steps 1 and 7, followed by $\mathrm{r} 11$ - 'Interoperability and APIs', mainly associated to Step 7. Then, r10 - 'Modelling conventions and guidelines' comes, which is especially associated to Step 4 (BIM modelling). However, both $\mathrm{r} 10$ and $\mathrm{r} 11$ are quite addressed within all the steps.

As for ambitions, it is interesting to see how the colour in the heatmap (Figure 25) is quite spread throughout the table, showing how many requirements are related to many of the steps and how it is necessary to consider many aspects for achieving successful results. 


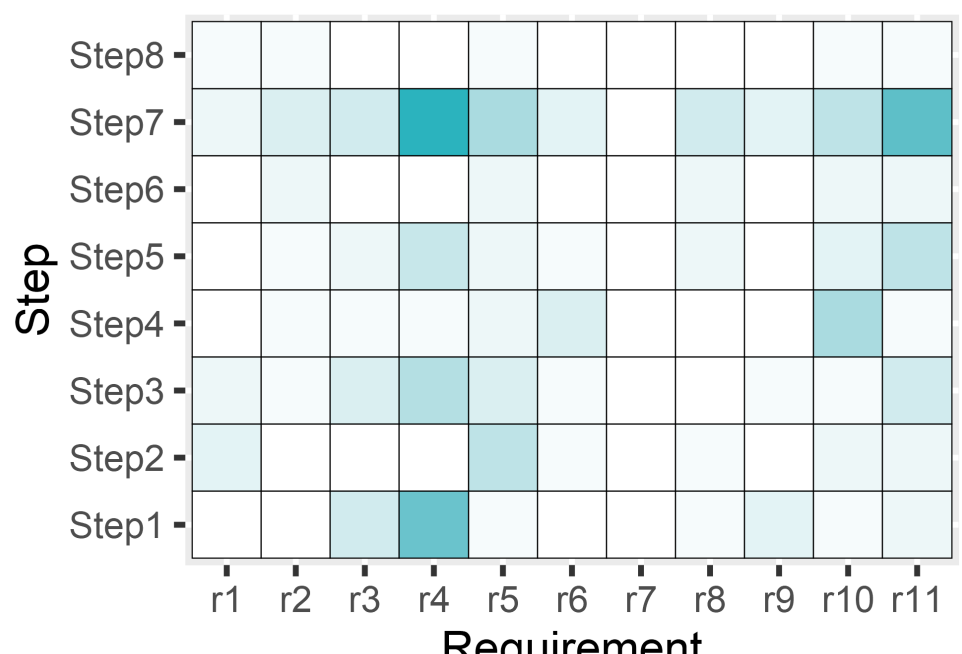

Figure 25: Heatmap showing the more addressed requirements to reach the EUnet4DBP ambitions in each step.

\subsection{Developments Gaps and direction for DBP}

This was the first time that such a critical literature review on the DBP was conducted, by classifying the reviewed contributions according to specific criteria and a pre-defined coding schema (DBP process step, kind of contribution, level of progress, addressed EUnet4DBP ambitions and related requirements) allowing a more accurate interpretation of the state of the art. Moreover, the focus on each step of the reference workflow can clearly point out what the possible unbalances and gaps are with respect to their investigation and provision of specific solutions. In fact, a step which is not suitably addressed could mean that the workflow would have issues at that point instead of getting smoothly to the end.

We could see that in general the reviewed contributions seldom arrive at a higher implementation level than B1 (demonstrators and proof-of-concepts) and most of the times have a low from intermediate progress (Executing or Validating). Moreover, also fundamental basic research is often missing: while we have a lot of applied scientific approaches, we see that there are low contributions to A1.

Regulations checking (i.e., Step 7) is the most investigated topic and the DBP process step which can reach a higher maturity.

We can see that the major gaps are currently related to the use of geoinformation (Step 2), especially in association with the BIM and reciprocal conversions (Step 6). Some further GeoBIM studies are being developed in the last years, but not directly related to DBP.

The Pre-consultation phase (Step 3) is also addressed in few studies at the moment, probably because requiring different issues to be solved preliminarily, such as interpretation and digitalization of regulations and the setting of a proper platform including and based on geoinformation-related data. Moreover, it could be seen as low priority, at the moment, for enabling the DBPs, and could still provisionally remain partially manual and 
human-based. A similar reasoning could be done for Step 8.

Step 4 and step 5, about the modelling and export of the BIM and its validation is also still little investigated and do not often reach a high level of maturity, which is instead an essential enabling condition for DBP and even for a successful application of Step 7.

To summarize, admitting as secondary Step 3 and Step 8, priority in research and development should be given, at the moment, to the data and interoperability issues involved in the Steps 2, 4, 5, 6 .

Looking at the addressed EUnet4DBP ambitions, we see that many are still neglected:

- T1 - Interoperable scalable systems useful at different levels (European, national, municipality) and in different countries;

- T3 - Platforms allowing a data-centric approach across the whole facility life-cycle by means of a central management of accesses;

- P2 - Align the process at EU level;

- E1 - Mindset change of public officers.

Moreover, we could notice, from processing this review, that one further ambition should be added to the list, namely: X1-Common understanding of DBP-related concepts. Being a very multidisciplinary topic, the diverse stakeholders and researchers, from different fields, should have the same understanding of the useful terms and concepts related to the building permit digitalization.

Also in the list of requirements there are many which are not yet at the center of current investigations in literature, especially:

- $r 1$ - Digitalize the mindset of public officers;

- r7 - Alignment across Europe and beyond, in Scope and Ambition (having connection with ambitions T1 and P2);

- r9-Common Dictionaries.

Some others, more addressed but still marginal are:

- r2 - A roadmap and a change framework towards a fully digital building permit process;

- r3 - Normative text should be interpretable;

- r6 - Understanding the necessary process steps.

Finally, $\mathrm{r} 5$ - Several kinds of data can be involved in the process (GIS, BIM, etc.), with related clear information 
requirements - is becoming more interesting for the DBP community in the last years, but still do not reach the amount of investigations reserved to $\mathrm{r} 4, \mathrm{r} 10$, and $\mathrm{r} 11$.

\section{Conclusion}

In this paper we have investigated the current state of the art related to the DBP use case, starting from a literature review the items of which have been classified by a multidisciplinary team according to the level of implementation, level of progress, addressed ambitions as defined by the EUnet4DBP and related requirements. Moreover, the items were grouped according to the specific steps of a reference workflow in which they could bring relevant contribution. In this way, we could outline with high detail how much each aspect of the very complex topic of digitalization of building permitting process has been currently tackled.

The investigation pointed out how major efforts are currently done for the regulations digitalization and the technological aspects, mainly for automating the compliance checks to regulations.

All other important subjects are instead still behind, including the mindset change of public officers; scalability of the solutions (process and technology); interoperability-related topics such as the IFC data validation and what concerns the use of geoinformation and the GeoBIM integration; development of platforms allowing the management of many involved processing in a unique environment.

It is important to note that the digitalization of building permitting is a complex task because it affects a broad range of sectors. A successful and efficient transition can be put into practice if a great number of sectors participate in this transition and evolve based on the needs with respect to prospective procedural and legislative changes. Interoperability between different organizations is of significance in terms of data exchange regarding DBP. Integrating the standards into processes is considered the most efficient way. At this point, it can be highlighted that the countries can use these standards as a basis to create national standards that meet countries' specific requirements within DBP.

This study is mainly based on literature and, although integrated on the base of the knowledge of the multidisciplinary authors and a questionnaire to externals, there could be initiatives not reported in literature which are however valuable for some of the investigated aspects. For example, the software which are already on the market offer valuable solutions for regulation checking, at a quite advanced progress, although limitations of software are often with the alignment to the specific checking needs in practice and with the other steps. Moreover, even if regulations checking tools are available, a major issue is the need to provide valid and suitable IFC models as input, or GeoBIM models, which are not ready yet.

The classification was difficult in some cases, and there was the risk that either the categories could be ambiguous, or the authors could be biased with respect to some of them. To limit this we revised the classifications and discussed in several meetings in order to agree on a common understanding, and decided to make the classification of each item by at least two people, having different background. In this way we could limit the 
differences in interpretation. work of F.N. was funded by the European Union's Horizon 2020 research and innovation programme under the Marie Skłodowska-Curie grant agreement No 707404, project "Multisource spatial data integration for smart city applications".

This work was very relevant to analyze the state of the art in the DBP use case because only by decomposing this complex topic in its parts it is possible to understand the current progress and proceed further to fill the gaps with a specific focus.

Future work could integrate the review with new contributions, and especially it would be interesting to repeat the investigation after some years to include the many developments which are currently ongoing. Also other documents or experiences than the ones documented in literature should be integrated with a more systematic work concerning them, including the documents available in national languages. Besides this, future steps should be directed at filling the gaps pointed out by this study and reach higher progress and implementation in all the parts of DBP use case.

\section{Acknowledgements}

This study was conceived and developed within the collaboration among the EUnet4DBP participants. The

\section{References}

[1] Department for Communities and Local Government. Plain English Guide to the Planning System. (January):20, 2015. URL https://assets.publishing.service.gov.uk/government/uploads/system/uploads/attachment_data/file/391694/Plai n_English_guide_to_the_planning_system.pdf.

[2] Renard Y.J. Siew, Maria C.A. Balatbat, and David G. Carmichael. A review of building/infrastructure sustainability reporting tools (SRTs). Smart and Sustainable Built Environment, 2(2):106-139, 2013. ISSN 20466102. doi: 10.1108/SASBE-03-2013-0010.

[3] European Commission. Digitalisation in the Construction Sector. Technical report, 2021. URL https://ec.europa.eu/docsroom/ documents/45547/attachments/1/translations/en/renditions/native.

[4] European Union. Supporting Digitalisation of the Construction Sector and SMEs (Including Building Information Modelling). Technical report, 2019. URL https://ec.europa.eu/docsroom/documents/38281/attachments/1/translations/en/renditions/n ative.

[5] E Hjelseth. Classification of BIM-based Model checking concepts. Journal of Information Technology in Construction, 21:354-370, 2016.

[6] H Narayanswamy, H Liu, and M Al-Hussein. BIM-based automated design checking for building permit in the light-frame building industry. In Proceedings of the 36th International Symposium on Automation and Robotics in Construction, ISARC 2019, pages 1042-1049, 2019

[7] Aimi Sara Ismail, Kherun Nita Ali, and Noorminshah A lahad. A Review on BIM-Based Automated Code Compliance Checking System. In 2017 5th International Conference on Research and Innovation in Information Systems (ICRIIS 2017): Social Transformation through Data Science, International Conference on Research and Innovation in Information Systems, 2017. ISBN 978-1-5090-3035-4.

[8] M Aydın and $\mathrm{H}$ Yaman. Domain knowledge representation languages and methods for building regulations. Communications in Computer and Information Science, 1188 CCIS:101-121, 2020. doi: 10.1007/978-3-030-42852-5_9.

[9] D Greenwood, S Lockley, S Malsane, and J Matthews. Automated compliance checking using building information models. In COBRA 2010 - Construction, Building and Real Estate Research Conference of the Royal Institution of Chartered Surveyors, 2010.

[10] Judith Ponnewitz and Sarah Schneider. Stand der Forschung zu BIM-basierten Baugenehmigungsprozessen. In 31. Forum Bauinformatik, pages 33-40, Berlin, 2019.

[11] C. Eastman, Jae min Lee, Yeon suk Jeong, and Jin kook Lee. Automatic rule-based checking of building designs. Automation in Construction, 18(8):1011-1033, 2009. ISSN 09265805. doi: 10.1016/j.autcon.2009.07.002.

[12] Hyunsoo Lee, Jin Kook Lee, Seokyung Park, and Inhan Kim. Translating building legislation into a computer-executable format for evaluating building permit requirements. Automation in Construction, 71:49-61, 2016. ISSN 09265805. doi: 10.1016/j.autcon.201 6.04 .008

[13] Kamellia Shahi, Brenda Y. McCabe, and Arash Shahi. Framework for Automated Model-Based e-Permitting System for Municipal Jurisdictions. Journal of Management in Engineering, 35(6):04019025, nov 2019. ISSN 0742-597X. doi: 10.1061/(ASCE)ME.19 43-5479.0000712. URL http://ascelibrary.org/doi/10.1061/\{\%\}28ASCE\{\%\}29ME. 1943-5479.0000712. 
[14] D. Plazza, M. Röck, G. Malacarne, A. Passer, C. Marcher, and D. T. Matt. BIM for public authorities: Basic research for the standardized implementation of BIM in the building permit process. In IOP Conference Series: Earth and Environmental Science, volume 323, page 12102, 2019. doi: 10.1088/1755-1315/323/1/012102.

[15] Jeff Clement Samasoni, James Olabode, and Bamidele Rotimi. an Exploratory Evaluation of a New National Online Consenting System in New Zealand. In 14th International Conference on Construction Applications of Virtual Reality in Construction Conference on Islamic Architecture, volume i. Teesside University, 2014.

[16] Future Insight Group, Rick Klooster, Judith Van Deth, Léon Van Berlo, and Stephan Meijer. Final report of: Introducing a Building Information Model (BIM)-based process for building permits in Estonia, 2019. URL https://eehitus.ee/wp-content/uploads/ 2019/11/2019-07-19-BIM-based-building-permits-Technical-Report.pdf.

[17] AS PricewaterhouseCoopers Advisors. Mapping, optimizing and adjusting for the introduction of e-construction of the procedures of the Register of Buildings - Final report, 2019. URL https ://eehitus.ee/wp-content/uploads/2019/07/MKM_PwC_EHR_optim izing_Register_of_Buildings_final_report_ENG.pdf.

[18] Cdbb. Digital COMpliance D-COM : Digitisation of Requirements, Regulations and Compliance Checking Processes in the Built Environment Final Report. 2019. URL https://www.dcom.org.uk/wp-content/uploads/2019/03/Final-Report-Anon.pdf.

[19] McKinsey. Smart Cities: Digital Solutions for a More Livable Future. Technical report, 2018. URL https://www .mckinsey . com/b usiness-functions/operations/our-insights/smart-cities-digital-solutions-for-a-more-livable-future.

[20] Sagar Malsane, Jane Matthews, Steve Lockley, Peter E.D. Love, and David Greenwood. Development of an object model for automated compliance checking. Automation in Construction, 49(PA):51-58, 2015. ISSN 09265805. doi: 10.1016/j.autcon.2014. 10.004

[21] B Gauthiez and O Zeller. Lyons, the spatial analysis of a city in the 17th and 18th centuries. Locating and crossing data in a GIS built from written sources. Lecture Notes in Geoinformation and Cartography, (9783319009926):97-118, 2014. doi: 10.1007/9783-319-00993-3_5

[22] J Hainc, T Hudeček, J Čtyroký, Z Vojtíšková, and A Gardoňová. Long term sustainable development of Prague, Czech Republic: Proposal for changes in administrative division for the authorization of new construction. WIT Transactions on Ecology and the Environment, 238:35-45, 2019. doi: 10.2495/SC190041.

[23] Chris Davis and Tim Schaub. A transboundary study of urban sprawl in the Pacific Coast region of North America: The benefits of multiple measurement methods. International Journal of Applied Earth Observation and Geoinformation, 7(4):268-283, dec 2005. ISSN 03032434. doi: 10.1016/j.jag.2005.06.007.

[24] Melissa Shakro. Tracking neighborhood development and behavioral trends with building permits in Austin, Texas. Journal of Maps, 9(2):189-197, 2013. ISSN 17445647. doi: 10.1080/17445647.2013.796575.

[25] R Cellmer and J Jasiński. Analysis of housing development activity in Poland from 2005-2014. Real Estate Management and Valuation, 24(4):47-58, 2016. doi: 10.1515/remav-2016-0029.

26] J Ponnewitz and H.-J. Bargstaedt. The building permit - How to standardize traditionally established processes. In 20th Congress of IABSE, New York City 2019: The Evolving Metropolis - Report, pages 1561-1565, 2019.

[27] M Messaoudi and N O Nawari. Virtual Permitting Framework for Off-site Construction Case Study: A Case Study of the State of Florida. Lecture Notes in Civil Engineering, 98:757-771, 2021. doi: 10.1007/978-3-030-51295-8_52.

[28] Mouloud Messaoudi, Nawari O Nawari, and Ravi Srinivasan. Virtual Building Permitting Framework for the State of Florida: Data Collection and Analysis. In C Cho, YK and Leite, F and Behzadan, A and Wang, editor, Computing in Civil Engineering 2019: Visualization, Information Modeling, and Simulation, pages 328-335. Amer Soc Civil Engineers, Comp Div; Amer Soc Civil Engineers, 2019. ISBN 978-0-7844-8242-1

[29] Judith Ponnewitz. Bim-based building permit procedures using decision making methods. 2017.

[30] M Whitell, Y Cao, B Y McCabe, A Shahi, M De Lint, and K Shahi. Standardizing Ontario's Permitting Process for E-Permitting Implementation. In Construction Research Congress 2020: Project Management and Controls, Materials, and Contracts - Selected Papers from the Construction Research Congress 2020, pages 1339-1348, 2020.

[31] Francesca Noardo, Avril Behan, Benedicte Bucher, Emmanuel Devys, Claire Ellul, Lars Harrie, Jan Hjelmager, Rollo Home, Marie Hornum, Joonas Jokela, Michal Klusek, Tobias Kellenberger, Anka Lisec, Thomas Lithén, Nancy Niemann, Ivar Overland, Maria Pla, Santi Sanchez, Peter West-Nielsen, and Jantien Stoter. EuroSDR GeoBIM project - Integrated Workflow using GeoBIM information for building permit process, July 2020. URL https://doi.org/10.5281/zenodo. 3948493.

[32] Francesca Noardo, C. Ellul, L. Harrie, I. Overland, M. Shariat, Ken Arroyo Ohori, and Jantien Stoter. Opportunities and challenges for GeoBIM in Europe: developing a building permits use-case to raise awareness and examine technical interoperability challenges. Journal of Spatial Science, 65(2):209-233, may 2020. ISSN 1449-8596. doi: 10.1080/14498596.2019.1627253. URL https: //www.tandfonline.com/doi/full/10.1080/14498596.2019.1627253.

[33] Inhan Kim, Jungsik Choi, Evelyn Ai Lin Teo, and Hongwei Sun. Development of kbim e-submission prototypical system for the openbim-based building permit framework. Journal of Civil Engineering and Management, 26(8):744-756, nov 2020. ISSN 18223605. doi: 10.3846/jcem.2020.13756. URL https://journals.vgtu.lt/index.php/JCEM/article/view/13756.

[34] Dogus Guler and Tahsin Yomralioglu. A reformative framework for processes from building permit issuing to property ownership in Turkey. Land Use Policy, 101:105115, feb 2021. ISSN 02648377. doi: 10.1016/j.landusepol.2020.105115.

[35] ISO. ISO 19650-1:2018 Organization and digitization of information about buildings and civil engineering works, including building information modelling (BIM) — Information management using building information modelling — Part 1: Concepts and principles, 2018.

[36] P. Teicholz, G. Lee, C. Eastman, and R. Sachs. BIM Handbook: A Guide to Building Information Modeling for Owners, Designers, Engineers, Contractors, and Facility Managers. John Wiley \& Sons, Inc., Hoboken, New Jersey, 3rd edition, 2018. ISBN 978-1-11928753-7.

[37] NBC. 10th Annual BIM Report. Technical report, 2020. URL https://www . thenbs . com/knowledge/national-bim-report-2020.

[38] ISO. ISO 16739-1:2018, Industry Foundation Classes (IFC) for data sharing in the construction and facility management industries - Part 1: Data schema, 2018.

[39] Filip Biljecki, Jantien Stoter, Hugo Ledoux, Sisi Zlatanova, and Arzu Çöltekin. Applications of 3d city models: State of the art review. ISPRS International Journal of Geo-Information, 4(4):2842-2889, 2015

[40] Romain Nouvel, Maryam Zirak, Volker Coors, and Ursula Eicker. The influence of data quality on urban heating demand modeling using 3d city models. Computers, Environment and Urban Systems, 64:68-80, 2017.

[41] Laura Romero Rodríguez, Eric Duminil, José Sánchez Ramos, and Ursula Eicker. Assessment of the photovoltaic potential at urban level based on 3d city models: A case study and new methodological approach. Solar Energy, 146:264-275, 2017.

[42] Sepideh Saeidi, Seyed Hamed Mirkarimi, Marjan Mohammadzadeh, Abdolrassoul Salmanmahiny, and Colin Arrowsmith. Assessing the visual impacts of new urban features: coupling visibility analysis with $3 \mathrm{~d}$ city modelling. Geocarto International, 34(12):1315$1331,2019$.

[43] Mezyad M. Alterkawi. Measures towards a comprehensive municipal gis—the case of ar-riyadh municipality. Habitat International, 
pages 689-698, 2005.

[44] Filip Biljecki, Kavisha Kumar, and Claus Nagel. Citygml application domain extension (ade): overview of developments. Open Geospatial Data, Software and Standards, 3(1):1-17, 2018.

[45] Francesca Noardo, Ken Arroyo Ohori, Filip Biljecki, Claire Ellul, Lars Harrie, Thomas Krijnen, Helen Eriksson, Jordi van Liempt, Maria Pla, Antonio Ruiz, Dean Hintz, Nina Krueger, Cristina Leoni, Leire Leoz, Diana Moraru, Stelios Vitalis, Philipp Willkomm, and Jantien Stoter. Reference study of CityGML software support: the GeoBIM benchmark 2019 - Part II. Transactions in GIS, 2021.

[46] Hugo Ledoux, Ken Arroyo Ohori, Kavisha Kumar, Balázs Dukai, Anna Labetski, and Stelios Vitalis. Cityjson: A compact and easy-to-use encoding of the citygml data model. Open Geospatial Data, Software and Standards, 4(1):1-12, 2019.

[47] Stelios Vitalis, Ken Arroyo Ohori, and Jantien Stoter. Cityjson in qgis: Development of an open-source plugin. Transactions in GIS, 24(5):1147-1164, 2020.

[48] Stelios Vitalis, Ken Arroyo Ohori, and Jantien Stoter. Incorporating topological representation in 3d city models. ISPRS International Journal of Geo-Information, 8(8):347, 2019.

[49] Gilles-Antoine Nys, Florent Poux, and Roland Billen. Cityjson building generation from airborne lidar $3 \mathrm{~d}$ point clouds. ISPRS International Journal of Geo-Information, 9(9):521, 2020.

[50] Enrico Prataviera, Pierdonato Romano, Laura Carnieletto, Francesco Pirotti, Jacopo Vivian, and Angelo Zarrella. Eureca: an open-source urban building energy modeling tool for the efficient evaluation of cities energy demand. Renewable Energy, 2021.

[51] Karin Staring. CityJSON in combination with MongoDB, PostgreSQL and GraphQL, 2020. URL https://repository.tudelft.n 1/islandora/object/uuid:7f9209f7-248f-4c93-9ba3-5866655e6040/datastream/OBJ/download.

[52] Xin Liu, Xiangyu Wang, Graeme Wright, Jack C.P. Cheng, Xiao Li, and Rui Liu. A state-of-the-art review on the integration of Building Information Modeling (BIM) and Geographic Information System (GIS). ISPRS International Journal of Geo-Information, 6 (2):53, 2017. ISSN 22209964. doi: 10.3390/ijgi6020053.

[53] Richelle Fosu, Kamal Suprabhas, Zenith Rathore, and Clark Cory. Integration of Building Information Modeling ( BIM ) and Geographic Information Systems ( GIS ) - a literature review and future needs. In Proc. of the 32nd CIB W78 Conference 2015, 27th-29th October 2015, Eindhoven, The Netherlands, pages 196-204, 2015.

[54] Ken Arroyo Ohori, Abdoulaye Diakité, Thomas Krijnen, Hugo Ledoux, and Jantien Stoter. Processing BIM and GIS models in practice: Experiences and recommendations from a GeoBIM project in the Netherlands. ISPRS International Journal of GeoInformation, 7(8), aug 2018.

[55] Sun, Mi, Olsson, Paulsson, and Harrie. Utilizing BIM and GIS for Representation and Visualization of 3D Cadastre. ISPRS International Journal of Geo-Information, 8(11):503, 2019. ISSN 2220-9964. doi: 10.3390/ijgi8110503.

[56] Filip Biljecki, Joie Lim, James Crawford, Diana Moraru, Helga Tauscher, Amol Konde, Kamel Adouane, Simon Lawrence, Patrick Janssen, and Rudi Stouffs. Extending citygml for ifc-sourced 3d city models. Automation in Construction, 121:103440, 2021.

[57] Kavisha Kumar, Anna Labetski, Ken Arroyo Ohori, Hugo Ledoux, and Jantien Stoter. The landinfra standard and its role in solving the bim-gis quagmire. Open geospatial data, software and standards, 4(1):1-16, 2019.

[58] Francesca Noardo, Lars Harrie, Ken Arroyo Ohori, Filip Biljecki, Claire Ellul, Thomas Krijnen, Helen Eriksson, Dogus Guler, Dean Hintz, Mojgan A. Jadidi, Maria Pla, Santi Sanchez, Ville Pekka Soini, Rudi Stouffs, Jernej Tekavec, and Jantien Stoter. Tools for BIM-GIS integration (IFC georeferencing and conversions): Results from the GeoBIM benchmark 2019. ISPRS International Journal of Geo-Information, 9(9):1-33, aug 2020. ISSN 22209964. doi: 10.3390/ijgi9090502. URL https://www.mdpi.com/222 $0-9964 / 9 / 9 / 502$.

[59] F. Noardo, G. Malacarne, S. Mastrolembo Ventura, L. C. Tagliabue, A. L. C. Ciribini, C. Ellul, D. Guler, L. Harrie, L. Senger, A. Waha, and J. Stoter. Integrating Expertises and Ambitions for Data-Driven Digital Building Permits - the EUNET4DBP. In ISPRS International Archives of the Photogrammetry, Remote Sensing and Spatial Information Sciences, volume XLIV-4/W1-, pages 103110, sep 2020. doi: 10.5194/isprs-archives-XLIV-4-W1-2020-103-2020. URL https://www . int-arch-photogramm-remote-s ens-spatial-inf-sci.net/XLIV-4-W1-2020/103/2020/.

[60] Linyan Chen, Albert P.C. Chan, Emmanuel K. Owusu, Amos Darko, and Xin Gao. Critical success factors for green building promotion: A systematic review and meta-analysis. Building and Environment, 207:108452, jan 2022. ISSN 0360-1323. doi: 10.1016/J.BUILDENV.2021.108452.

[61] Lisanne Bergefurt, Minou Weijs-Perrée, Rianne Appel-Meulenbroek, and Theo Arentze. The physical office workplace as a resource for mental health - A systematic scoping review. Building and Environment, 207:108505, jan 2022. ISSN 0360-1323. doi: 10.101 6/J.BUILDENV.2021.108505. URL https://linkinghub.elsevier.com/retrieve/pii/S0360132321009008.

[62] Larissa Arakawa Martins, Veronica Soebarto, and Terence Williamson. A systematic review of personal thermal comfort models. Building and Environment, 207:108502, jan 2022. ISSN 0360-1323. doi: 10.1016/J.BUILDENV.2021.108502. URL https: //linkinghub.elsevier.com/retrieve/pii/S0360132321008970.

[63] Seungwon Baek, Wooyong Jung, and Seung H. Han. A critical review of text-based research in construction: Data source, analysis method, and implications. Automation in Construction, 132:103915, dec 2021. ISSN 0926-5805. doi: 10.1016/J.AUTCON.2021. 103915.

[64] Marco Marocco and Ilaria Garofolo. Integrating disruptive technologies with facilities management: A literature review and future research directions. Automation in Construction, 131:103917, nov 2021. ISSN 0926-5805. doi: 10.1016/J.AUTCON.2021.103917.

[65] Denis J. Scott, Tim Broyd, and Ling Ma. Exploratory literature review of blockchain in the construction industry. Automation in Construction, 132:103914, dec 2021. ISSN 0926-5805. doi: 10.1016/J.AUTCON.2021.103914.

[66] Francesca Noardo and Giada Malacarne. Digital building permit: a state of play - I EUnet4DBP International workshop on Digital Building Permit, 2021. URL http://www.eurosdr.net/sites/default/files/uploaded_files/eurosdr_eunet4dbp.pdf.

980 [67] EUnet4DBP. Questionnaire description, 2021. URL https://3d.bk.tudelft.nl/projects/eunet4dbp/Survey.pdf.

[68] A Guide. Project management body of knowledge (pmbok® guide). In Project Management Institute, 2001.

[69] Botao Zhong, Haitao Wu, Heng Li, Samad Sepasgozar, Hanbin Luo, and Ling He. A scientometric analysis and critical review of construction related ontology research. Automation in Construction, 101:17-31, may 2019. ISSN 09265805. doi: 10.1016/j.autc on.2018.12.013. URL https://linkinghub.elsevier.com/retrieve/pii/S0926580518305648.

[70] F. Noardo, T. Wu, K. Arroyo Ohori, T. Krijnen, H. Tezerdi, and J. Stoter. Geobim for digital building permit process: Learning from a case study in Rotterdam. In ISPRS Annals of the Photogrammetry, Remote Sensing and Spatial Information Sciences, volume 6, pages 151-158, 2020. doi: 10.5194/isprs-annals-VI-4-W1-2020-151-2020.

[71] L. Van Berlo, T. Dijkmans, and J. Stoter. Experiment for integrating Dutch 3D spatial planning and bim for checking building permits. In ISPRS Annals of the Photogrammetry, Remote Sensing and Spatial Information Sciences, volume 2, pages 279-284. ISPRS, 2013. doi: 10.5194/isprsannals-II-2-W1-279-2013.

[72] T H Beach and Y Rezgui. Semantic encoding of construction regulations. In CEUR Workshop Proceedings, volume 2159, pages 52-61, 2018.

[73] Nicholas Nisbet, Jeffrey Wix, and David Conover. The Future of Virtual Construction and Regulation Checking. In Virtual Futures for Design, Construction \& Procurement, chapter 17, pages 241-250. John Wiley \& Sons, Ltd, feb 2009. doi: 10.1002/9781444302 
349. $\mathrm{CH} 17$.

[74] Sibel Macit İlal and H. Murat Günaydın. Computer representation of building codes for automated compliance checking. Automation in Construction, 82:43-58, 2017. ISSN 09265805. doi: 10.1016/j.autcon.2017.06.018.

[75] Jiansong Zhang and Nora M. El-Gohary. Extending building information models semiautomatically using semantic natural language processing techniques. Journal of Computing in Civil Engineering, 30(5):C4016004, 2016. doi: 10.1061/(ASCE)CP.1943-5487.00 00536.

[76] J Song, J Kim, and J.-K. Lee. NLP and deep learning-based analysis of building regulations to support automated rule checking system. In ISARC 2018 - 35th International Symposium on Automation and Robotics in Construction and International AEC/FM Hackathon: The Future of Building Things, 2018.

[77] Jiansong Zhang and Nora M. El-Gohary. Integrating semantic NLP and logic reasoning into a unified system for fully-automated code checking. Automation in Construction, 73:45-57, jan 2017. ISSN 09265805. doi: 10.1016/j.autcon.2016.08.027. URL https://linkinghub.elsevier.com/retrieve/pii/S0926580516301819.

[78] R Zhang and N El-Gohary. A Machine-Learning Approach for Semantic Matching of Building Codes and Building Information Models (BIMs) for Supporting Automated Code Checking. Sustainable Civil Infrastructures, pages 64-73, 2020. doi: 10.1007/978-3-03034216-6_5.

[79] J Song, J Kim, and J.-K. Lee. Converting KBImCode into an executable code for the automated design rule checking system. In Intelligent and Informed - Proceedings of the 24th International Conference on Computer-Aided Architectural Design Research in Asia, CAADRIA 2019, volume 1, pages 795-804, 2019.

[80] S Park, Y.-C. Lee, and J.-K. Lee. Definition of a domain-specific language for Korean building act sentences as an explicit computable form. Journal of Information Technology in Construction, 21:422-433, 2016.

[81] S Park and J.-K. Lee. KBimCode-based applications for the representation, definition and evaluation of building permit rules. In ISARC 2016 - 33rd International Symposium on Automation and Robotics in Construction, pages 720-728, 2016.

[82] Jinsung Kim, Jin Kook Lee, Jaeyoung Shin, and Hayan Kim. Classification of objects and their properties defined in Korea building act to translate into KBimCode and their application. In ISARC 2017 - Proceedings of the 34th International Symposium on Automation and Robotics in Construction, pages 148-155, 2017. doi: 10.22260/isarc2017/0020.

[83] H Lee, S Lee, S Park, and J.-K. Lee. An approach to translate Korea building act into computer-readable form for automated design assessment. In 32nd International Symposium on Automation and Robotics in Construction and Mining: Connected to the Future, Proceedings, 2015.

[84] N Nawari. The challenge of computerizing building codes in a BIM environment. In Congress on Computing in Civil Engineering, Proceedings, pages 285-292, 2012. doi: 10.1061/9780784412343.0036.

[85] Helen Eriksson, Tim Johansson, Per Ola Olsson, Maria Andersson, Jakob Engvall, Isak Hast, and Lars Harrie. Requirements, development, and evaluation of a national building standard-a Swedish case study. ISPRS International Journal of Geo-Information, 9(2):78, jan 2020. ISSN 22209964. doi: 10.3390/ijgi9020078. URL https://www.mdpi . com/2220-9964/9/2/78.

[86] Nebras Salheb, K Arroyo Ohori, and J Stoter. Automatic conversion of citygml to ifc. International Archives of the Photogrammetry, Remote Sensing and Spatial Information Sciences, 44(4/W1):127-134, 2020.

[87] Sébastien Chognard, Alain Dubois, Yacine Benmansour, Elie Torri, and Bernd Domer. Digital Construction Permit: A Round Trip Between GIS and IFC. In Lecture Notes in Computer Science (including subseries Lecture Notes in Artificial Intelligence and Lecture Notes in Bioinformatics), volume 10864 LNCS, pages 287-306. Springer Verlag, 2018. ISBN 9783319916378. doi: 10.1007/978-3-319-91638-5_16. URL http://link. springer.com/10.1007/978-3-319-91638-5\{_\}16.

[88] Christian Clemen, Tim Kaiser, Enrico Romanschek, and Marcus Schröder. Site Plan for BIM?-A Free and Open Source Plug-In for As-Is Vicinity Models to be Used in Small and Medium-Sized BIM-Projects. In FIG e-Working Week $2021,2021$.

[89] J Dimyadi, W Solihin, and D Marchant. The design brief: Requirements and compliance. Journal of Information Technology in Construction, 21:337-353, 2016.

[90] Hayan Kim, Jin-Kook Lee, Jaeyoung Shin, and Jungsik Choi. BIM-Supported Visual Language to Define Building Design Regulations. In MA Janssen, $\mathrm{P}$ and Loh, $\mathrm{P}$ and Raonic, A and Schnabel, editor, Proceedings of the 22nd International Conference on Computer-Aided Architectural Design Research in Asia (Caadria 2017): Protocols, Flows and Glitches, pages 603-612. Assoc Comp Aided Architectural Design Res Asia, 2017. ISBN 978-988-19026-8-9. URL http://papers.cumincad.org/data/works/a tt/caadria2017\{_\}135.pdf.

[91] Kristina Kincelova, Conrad Boton, Pierre Blanchet, and Christian Dagenais. Fire safety in tall timber building: A BIM-based automated code-checking approach. Buildings, 10(10), 2020. ISSN 20755309. doi: 10.3390/BUILDINGS10070121.

[92] Yelin Demir Altıntaş and Mustafa Emre llal. Loose coupling of GIS and BIM data models for automated compliance checking against zoning codes. Automation in Construction, 128:103743, aug 2021. ISSN 09265805. doi: 10.1016/j.autcon.2021.103743. URL https://linkinghub.elsevier.com/retrieve/pii/S0926580521001941.

[93] Tang Hung Nguyen and Jin Lee Kim. Building code compliance checking using BIM technology. In J Jain, S and Creasey, R and Himmelspach, editor, Proceedings - Winter Simulation Conference, Winter Simulation Conference Proceedings, pages 3395-3400. Amer Stat Assoc (ASA); Assoc Comp Machinery-Special Interest Grp Simulat (ACM/SIGSIM); Inst Elect \& Electron Engineers-Syst, Man, \& Cybernet Soc (IEEE/SMC); Inst Ind Engineers (IIE); Inst Operat Res \& Management Sci-Simulat Soc (INFORMS-SIM); Natl Inst St, 2011. ISBN 9781457721083. doi: 10.1109/WSC.2011.6148035. URL https://www.informs-sim.org/wsc11papers/30 $1 . p d f$.

[94] Kamellia Shahi, Brenda Y. McCabe, and Arash Shahi. Framework for automated model-based e-permitting systemfor municipal jurisdictions. Journal of Management in Engineering, 10(35), 2019.

[95] S.L. Urbanismo Visual. Información territorial y urbanística a la medida de tu proyecto description, 2020. URL https://www . visu alurb.es/.

[96] Boverket. National Board of Housing, Building and Planning description, 2020. URL https://www. boverket.se/en/start/.

[97] Cornelius Preidel and André Borrmann. Automated code compliance checking based on a visual language and building information modeling. volume 32. IAARC Publications, 2015. Proposal of concept of 'Visual Code Checking Languagequot;. Pilot application to the German fire code.

[98] Peng Zhou and Nora El-Gohary. Automated matching of design information in BIM to regulatory information in energy codes. In C Wang, C and Harper, C and Lee, Y and Harris, R and Berryman, editor, Construction Research Congress 2018: Construction Information Technology - Selected Papers from the Construction Research Congress 2018, volume 2018-April, pages 75-85. Amer Soc Civil Engineers, Construct Inst, Construct Res Council; Amer Soc Civil Engineers; Amer Soc Civil Engineers, Construct Inst, 2018. ISBN 9780784481264. doi: 10.1061/9780784481264.008.

[99] Tanya Bloch and Rafael Sacks. Clustering Information Types for Semantic Enrichment of Building Information Models to Support Automated Code Compliance Checking. JOURNAL OF COMPUTING IN CIVIL ENGINEERING, 34(6), 2020. ISSN 0887-3801. doi: 10.1061/(ASCE)CP.1943-5487.0000922. URL https ://ascelibrary.org/doi/abs/10.1061/\{\%\}28ASCE\{\%\}29CP.1943-548 7.0000922 . 
[100] Yong-Cheol Lee, Charles M Eastman, and Wawan Solihin. Logic for ensuring the data exchange integrity of building information models. Automation in Construction, 85:249-262, jan 2018. ISSN 09265805. doi: 10.1016/j.autcon.2017.08.010. URL https: //linkinghub.elsevier.com/retrieve/pii/S0926580517307276.

[101] Wawan Solihin, Naveed Shaikh, Xu Rong, and Khee Lam. Beyond interoperability of building model a case for code compliance checking. In BP-CAD Workshop, 2004.

[102] Estonia Ministry of Economic Affairs \& Communications. E-ehitus description, 2021. URL https://eehitus.ee/timeline-post /bim-based-building-permit-process/.

[103] Kouba and Masák. Nové sídlo nku, 2020. URL https://www.nku.cz/cz/pro-media/sidlo-nku/co-stavime/.

[104] L. A. van Berlo and E. Papadonikolaki. Facilitating the BIM coordinator and empowering the suppliers with automated data compliance checking. In R Christodoulou, SE and Scherer, editor, eWork and eBusiness in Architecture, Engineering and Construction - Proceedings of the 11th European Conference on Product and Process Modelling, ECPPM 2016, pages 145-154, 2016. ISBN 9781138032804

[105] Johansson. Slutrapport för projektet Leveransspecifikationer för Geodata-BIM description, 2020. URL https://www. smartbuilt .se/library/5377/ap3_slutrapport.pdf.

[106] Jiansong Zhang and Nora M. El-Gohary. Automated extraction of information from building information models into a semantic logic-based representation. 2015.

[107] J Zhang and N M El-Gohary. Automated extraction of information from building information models into a semantic logic-based representation. In Congress on Computing in Civil Engineering, Proceedings, volume 2015-January, pages 173-180, 2015. doi: $10.1061 / 9780784479247.022$.

[108] ALC Ciribini, S Mastrolembo Ventura, and Michela Paneroni. Implementation of an interoperable process to optimise design and construction phases of a residential building: A bim pilot project. Automation in construction, 71:62-73, 2016.

[109] J Choi and I Kim. A methodology of building code checking system for building permission based on openBIM. In ISARC 2017 - Proceedings of the 34th International Symposium on Automation and Robotics in Construction, pages 945-950, 2017. doi: $10.22260 /$ isarc2017/0131.

[110] N Bus, A Roxin, G Picinbono, and M Fahad. Towards French smart building code: Compliance checking based on semantic rules. In CEUR Workshop Proceedings, volume 2159, pages 6-15, 2018.

[111] Muhammad Fahad and Nicolas Bus. Conformance checking of IFC models via semantic BIM reasoner. In CEUR Workshop Proceedings, volume 2394, 2019.

[112] D Moult and T Krijnen. Compliance checking on building models with the gherkin language and continuous integration. In $E G-I C E$ 2020 Workshop on Intelligent Computing in Engineering, Proceedings, pages 294-303, 2020. doi: 10.14279/depositonce-9977.

[113] Pedram Ghannad, Yong Cheol Lee, Johannes Dimyadi, and Wawan Solihin. Automated BIM data validation integrating openstandard schema with visual programming language. Advanced Engineering Informatics, 40:14-28, 2019. ISSN 14740346. doi: 10.1016/j.aei.2019.01.006.

[114] Per-Ola Olsson, Josefine Axelsson, Martin Hooper, and Lars Harrie. Automation of Building Permission by Integration of BIM and Geospatial Data. ISPRS International Journal of Geo-Information, 7(8):307, jul 2018. ISSN 2220-9964. doi: 10.3390/ijgi7080307. URL http://www.mdpi.com/2220-9964/7/8/307.

[115] Ali İsmail and Mohammed Hamoud. Dubai BIM e-Submission Platform and BIM-GIS integration. In DIGITAL BUILDING PERMIT:A STATE OF PLAY. I EUnet4DBP International workshop on Digital Building Permit. EuroSDR, 2021.

[116] City of Järvenpää. The world's first 3D BIM model-approved building permit In Järvenpää?, 2021. URL https://jarvenpaa.kunt a3d.fi/Map.html?p=6705460.613\{\&\} $i=394952.154\{\&\} \mathrm{h}=49.606\{\&\} \mathrm{camE}=395076.1\{\&\} \mathrm{camH}=163.0\{\&\} \mathrm{camN}=6705355.1\{\&\} \mathrm{cam}$ RotX $=-0.686\{\&\}$ camRot $Y=0.792\{\&\}$ project $=45\{\&\}$ locale $=$ def ault .

[117] KIRA-digi. Adding BIM to the Digital Building Permit Process, 2018. URL http://www.kiradigi.fi/en/news/how-bim-is-revol utionizing-building-control-in-finland.html.

[118] Wu Jialun. A CityJSON extension to store city information towards the automation of building permit, 2021. URL https://3d.bk. tudelft.nl/ken/files/21_jialun.pdf.

[119] Min Ya Zhang. Automated building compliance checking: emphasis on building placement and parking availability. Master's thesis, 2019. URL https://lup.lub.lu.se/luur/download?func=downloadFile\&recordOId=8990783\&f ile0Id=8990784.

[120] Cype Ingenieros. ASPRIMA y CYPE desarrollan un software para reducir el tiempo de concesión de licencias urbanísticas description, 2021. URL http://noticias.cype.es/2017/cypeurban_asprima_bimserver_cent.htm.

[121] S Park, H Lee, S Lee, J Shin, and J.-K. Lee. Rule checking method-centered approach to represent building permit requirements. In 32nd International Symposium on Automation and Robotics in Construction and Mining: Connected to the Future, Proceedings, 2015.

[122] P Zhou and N El-Gohary. Text and Information Analytics for Fully Automated Energy Code Checking. Sustainable Civil Infrastructures, pages 196-208, 2019. doi: 10.1007/978-3-030-01905-1_11.

[123] P Pauwels, D Van Deursen, $R$ Verstraeten, J De Roo, R De Meyer, R. Van de Walle, and J Van Campenhout. A semantic rule checking environment for building performance checking. Automation in Construction, 20(5):506-518, aug 2011. ISSN 09265805. doi: 10.1016/j.autcon.2010.11.017. URL https://linkinghub.elsevier.com/retrieve/pii/S0926580510001962.

[124] Tala Kasim, Haijiang Li, Yacine Rezgui, and Thomas Beach. Integrated Framework to Manage Building's Sustainability Efficiency, Design Features and Building Envelope. In Y CamarinhaMatos, LM and Afsarmanesh, $\mathrm{H}$ and Rezgui, editor, IFIP Advances in Information and Communication Technology, volume 534 of IFIP Advances in Information and Communication Technology, pages 650-660. IFIP WG 55 COVE; Soc Collaborat Networks; Cardiff Univ; Nova Univ Lisbon; UNINOVA; Univ Amsterdam, 2018. ISBN 9783319991269. doi: 10.1007/978-3-319-99127-6_56.

[125] K Kincelova, C Boton, P Blanchet, and C Dagenais. BIM-based code compliance checking for fire safety in timber buildings: A comparison of existing tools. In Proceedings, Annual Conference - Canadian Society for Civil Engineering, volume 2019-June, 2019.

[126] Ozgun Balaban, Elif Sezen Yagmur Kilimci, and Gulen Cagdas. Automated Code Compliance Checking Model for Fire Egress Codes. In D Achten, $\mathrm{H}$ and Pavlicek, J and Hulin, J and Matejovska, editor, ECAADE 2012, VOL 2: PHYSICAL DIGITALITY, pages 117-125. Autodesk GmbH; Bentley Syst; Czech Tech Univ, Rectors Off, 2013. ISBN 978-9-4912070-3-7.

[127] Hanbin Luo and Peisong Gong. A BIM-based Code Compliance Checking Process of Deep Foundation Construction Plans. Journal of Intelligent and Robotic Systems: Theory and Applications, 79(3-4):549-576, aug 2015. ISSN 15730409. doi: 10.1007/s10846-0 14-0120-z.

[128] Jin-Kook Lee, Charles M Eastman, and Yong Cheol Lee. Implementation of a BIM Domain-specific Language for the Building Environment Rule and Analysis. Journal of Intelligent \& Robotic Systems, 79(3-4):507-522, aug 2015. ISSN 0921-0296. doi: 10.1007/s10846-014-0117-7. URL http://link. springer.com/10.1007/s10846-014-0117-7.

[129] EuroSDR. DIGITAL BUILDING PERMIT:A STATE OF PLAY. I EUnet4DBP International workshop on Digital Building Permit. Technical report, 2021. URL tbd. 
[130] E Hjelseth. BIM-based model checking (BMC). 2015. doi: 10.1061/9780784413982.ch02.

[131] Y C Lee, C M Eastman, and J K Lee. Automated rule-based checking for the validation of accessibility and visibility of a building information model. In Congress on Computing in Civil Engineering, Proceedings, volume 2015-Janua, pages 572-579, 2015. doi: 10.1061/9780784479247.071.

[132] Q.Z. Yang and Xingjian Xu. Design knowledge modeling and software implementation for building code compliance checking. Building and Environment, 39(6):689-698, jun 2004. ISSN 03601323. doi: 10.1016/j.buildenv.2003.12.004. URL https: //linkinghub.elsevier.com/retrieve/pii/S036013230300283X.

[133] Botao Zhong, Chen Gan, Hanbin Luo, and Xuejiao Xing. Ontology-based framework for building environmental monitoring and compliance checking under BIM environment. Building and Environment, 141:127-142, aug 2018. ISSN 03601323. doi: 10.1016/ j.buildenv.2018.05.046.

[134] Jaeyeol Song, Jin-Kook Lee, Jungsik Choi, and Inhan Kim. Deep learning-based extraction of predicate-argument structure (PAS) in building design rule sentences. Journal of Computational Design and Engineering, 7(5):563-576, oct 2020. ISSN 2288-5048. doi: 10.1093/jcde/qwaa046. URL https://academic.oup.com/jcde/article/7/5/563/5836985.

[135] J Dimyadi, W Solihin, C Preidel, and A Borrmann. Towards code compliance checking on the basis of a visual programming language. Journal of Information Technology in Construction, 21:402-421, 2016.

[136] Niedersächsische Bauordnung, 2020.

[137] City of Sant Feliu. Plataforma Smart Sant Feliu description, 2021. URL https://www. santfeliu. cat/go.faces?xmid=22791.

[138] J Soliman-Junior, J P Baldauf, P Tzortzopoulos, M Kagioglou, J S Humphreys, and C T Formoso. Improving healthcare design with BIM-based tools. In IOP Conference Series: Earth and Environmental Science, volume 588, 2020. doi: 10.1088/1755-1315/588/ $3 / 032003$.

[139] C Zhang and J Beetz. Querying linked building data using SPARQL with functional extensions. In R Christodoulou, SE and Scherer, editor, eWork and eBusiness in Architecture, Engineering and Construction, pages 27-34, 2016. ISBN 978-1-315-38690-4.

[140] Jiansong Zhang and Nora El-Gohary. An Automated Relationship Classification to Support Semi-Automated IFC Extension. In OI Perdomo-Rivera, JL and Gonzalez-Quevedo, A and Lopez DelPuerto, C and Maldonado-Fortunet, F and Molina-Bas, editor, Construction Research Congress 2016: Old and New Construction Technologies Converge in Historic San Juan - Proceedings of the 2016 Construction Research Congress, CRC 2016, pages 829-838. Amer Soc Civil Engineers, Construct Inst, Construct Res Council, 2016. ISBN 9780784479827. doi: 10.1061/9780784479827.084.

[141] Su Ling Fan, Hung Lin Chi, and Po Quan Pan. Rule checking Interface development between building information model and end user. Automation in Construction, 105, sep 2019. ISSN 09265805. doi: 10.1016/j.autcon.2019.102842.

[142] C. Métral, V. Daponte, A. Caselli, G. Di Marzo, and G. Falquet. Ontology-Based Rule Compliance Checking for Subsurface Objects. In International Archives of the Photogrammetry, Remote Sensing and Spatial Information Sciences - ISPRS Archives, volume 44, pages 91-94, 2020. doi: 10.5194/isprs-archives-XLIV-4-W1-2020-91-2020.

[143] Pin-Chan Lee, Tzu-Ping Lo, Ming-Yang Tian, and Danbing Long. An Efficient Design Support System based on Automatic Rule Checking and Case-based Reasoning. KSCE Journal of Civil Engineering, 23(5):1952-1962, may 2019. ISSN 1226-7988. doi: 10.1007/s12205-019-1750-2. URL http://link.springer.com/10.1007/s12205-019-1750-2.

[144] Í Guedes, M Andrade, and A Carvalho. BIM-Based Airport Design Project Standardization (IFC) for Use of Code Checking. Advances in Science, Technology and Innovation, pages 37-47, 2021. doi: 10.1007/978-3-030-57509-0_4.

[145] Jia Qi, Raja R.A. Issa, Svetlana Olbina, and Jimmie Hinze. Use of building information modeling in design to prevent construction worker falls. Journal of Computing in Civil Engineering, 28(5), sep 2014. ISSN 08873801. doi: 10.1061/(ASCE)CP.1943-5487.00 00365.

[146] Caterina Trebbi, Michelangelo Cianciulli, Francesco Matarazzo, Claudio Mirarchi, Guido Cianciulli, and Alberto Pavan. Clash Detection and Code Checking BIM Platform for the Italian Market. In Bruno Daniotti, Marco Gianinetto, and Stefano Della Torre, editors, Digital Transformation of the Design, Construction and Management Processes of the Built Environment, pages 115125. Springer International Publishing, Cham, 2020. ISBN 978-3-030-33570-0. doi: 10.1007/978-3-030-33570-0_11. URL https://doi.org/10.1007/978-3-030-33570-0\{_\}11.

[147] J Dimyadi, C Clifton, M Spearpoint, and R Amor. Regulatory knowledge encoding guidelines for automated compliance audit of building engineering design. In Computing in Civil and Building Engineering - Proceedings of the 2014 International Conference on Computing in Civil and Building Engineering, pages 536-543, 2014. doi: 10.1061/9780784413616.067.

[148] Hayan Kim, Jin Kook Lee, Jaeyoung Shin, and Jungsik Choi. Visual language approach to representing KBimCode-based Korea building code sentences for automated rule checking. Journal of Computational Design and Engineering, 6(2):143-148, 2019. ISSN 22885048. doi: 10.1016/j.jcde.2018.08.002.

[149] Nick Evans and John Counsell. Web-Mediated Student Peer Group Assessment of Building Information Modelling Performance. In 2009 Second International Conference in Visualisation, pages 85-89. IEEE, jul 2009. ISBN 978-0-7695-3734-4. doi: 10.1109/VI Z.2009.34.

[150] Ángel Mena, Fernando López, José Manuel Framiñan, Francisco Flores, and Juan Manuel Gallego. XPDRL project: Improving the project documentation quality in the Spanish architectural, engineering and construction sector. Automation in Construction, 19(2): 270-282, mar 2010. ISSN 09265805. doi: 10.1016/j.autcon.2009.10.001.

[151] Nawari O Nawari and Adel Alsaffar. The Role of BIM in Simplifying Construction Permits in Kuwait. In JS Volz, editor, AEI 2017: RESILIENCE OF THE INTEGRATED BUILDING, pages 855-866. Amer Soc Civil Engineers, Architectural Engn Inst; Amer Soc Civil Engineers, 2017. ISBN 978-0-7844-8050-2.

[152] J Choi, I Kim, M Kim, and J Ryu. A suggestion for improvement of IFC data in energy performance index (EPI) based on open BIM. In ISARC 2016 - 33rd International Symposium on Automation and Robotics in Construction, pages 529-537, 2016. doi: $10.22260 /$ isarc2016/0064.

[153] Muhammad Fahad and Nicolas Bus. Geolocation in the Semantic BIM. In Proceedings - 2019 IEEE International Conference on Engineering, Technology and Innovation, ICE/ITMC 2019, International ICE Conference on Engineering Technology and Innovation. IEEE; IEEE Technol \& Engn Management Soc; ICE; European Soc Concurrent Engn; R2M Solut, 2019. ISBN 9781728134017. doi: 10.1109/ICE.2019.8792580.

[154] Liz Shantalle Ricardo Belliard. Implementation of BIM in the Municipal Plan Review Process. Master's thesis, 2016. URL https: //scholarsarchive.byu.edu/etd/6069.

[155] T Strobbe, P Pauwels, R Verstraeten, R De Meyer, and J Van Campenhout. Optimization in compliance checking using heuristics: Flemish Energy Performance Regulations (EPR). In R Gudnason, G and Scherer, editor, eWork and eBusiness in Architecture, Engineering and Construction, pages 477-482, 2012. ISBN 978-0-415-62128-1.

[156] L Shi and D Roman. From standards and regulations to executable rules: A case study in the Building Accessibility domain. In CEUR Workshop Proceedings, volume 1875, 2017.

[157] M De Vos, S Kirrane, J Padget, and K Satoh. ODRL policy modelling and compliance checking. Lecture Notes in Computer Science (including subseries Lecture Notes in Artificial Intelligence and Lecture Notes in Bioinformatics), 11784 LNCS:36-51, 2019. doi: 
10.1007/978-3-030-31095-0_3.

[158] J Zdravkovic and A Ostman. An agile method for automated provisioning of the geographical information in public services. In S Coors, V and Rumor, M and Fendel, E and Zlatanova, editor, Urban and Regional Data Management, Proceedings and Monographs in Engineering, Water and Earth Sciences, pages 319-331. Urban Data Management Soc, 2008. ISBN 978-0-415-44059-2.

[159] Yong-Cheol Lee, Wawan Solihin, and Charles M Eastman. The Mechanism and Challenges of Validating a Building Information Model regarding data exchange standards. Automation in Construction, 100:118-128, apr 2019. ISSN 09265805. doi: 10.1016/j. autcon.2018.12.025. URL https://linkinghub.elsevier.com/retrieve/pii/S0926580517311305.

[160] H Karim, D A L Abu Seman, M A Mohamad Dali, S Z Othman, and S C Bernad. A Proposal to Implement Integrated GIS System in Disseminating Spatial Information for Malaysia Development Approval (Stakeholders and Applicants) - A Concept Paper. In ISPRS - International Archives of the Photogrammetry, Remote Sensing and Spatial Information Sciences, volume XLII-4/W16, pages 347-358, oct 2019. doi: 10.5194/isprs-archives-XLII-4-W16-347-2019.

[161] Francesca Noardo, Thomas Krijnen, Ken Arroyo Ohori, Filip Biljecki, Claire Ellul, Lars Harrie, Helen Eriksson, Lorenzo Polia, Nebras Salheb, Helga Tauscher, Jordi van Liempt, Hendrik Goerne, Dean Hintz, Tim Kaiser, Cristina Leoni, Artur Warchol, and Jantien Stoter. Reference study of IFC software support: the GeoBIM benchmark 2019 - Part I. Transactions in GIS, 25(2):805-841, 2021.

[162] Francesca Noardo, Ken Arroyo Ohori, Thomas Krijnen, and Jantien Stoter. An inspection of ifc models from practice. Applied Sciences, 11(5):2232, 2021.

[163] Trdla. Centrální depozitáŕ libereckého kraje, 2021. URL https://www.kraj-lbc.cz/aktuality/centralni-depozitar-vznikn e-za-pouziti-nove-metody-usetri-se-tim-penize-n1092019.htm.

[164] P Limsupreeyarat, S Kaewkeaw, and P Charnwasununt. Developing the GIS-expert system for investigating land use designations. In ISARC 2017 - Proceedings of the 34th International Symposium on Automation and Robotics in Construction, pages 720-724, 2017.

[165] Matteo Mandrile. BIM as a multiscale facilitator for built environment analysis. PhD thesis, Univerza v Ljubljani, Fakulteta za gradbeništvo in geodezijo, 2020. URL https://repozitorij .uni-lj.si/IzpisGradiva.php?lang=slv\&id=121115.

[166] T Krijnen and L.A.H.M. Van Berlo. Methodologies for requirement checking on building models: A technology overview. In Design and Decision Support Systems in Architecture and Urban Planning - 13th International Conference on Design and Decision Support Systems in Architecture and Urban Planning, DDSS 2016, 2016.

[167] Cornelius Preidel and André Borrmann. Automated code compliance checking based on a visual language and building information modeling. In ISARC. Proceedings of the International Symposium on Automation and Robotics in Construction, volume 32. IAARC Publications, 2015.

[168] TNO. BIM Bots description, 2018. URL https://www.tno.nl/en/tno-insights/articles/bim-bots-boost-construction-se ctor-productivity/.

[169] Wawan Solihin and Charles Eastman. A Knowledge Representation Approach in BIM Rule Requirement Analysis Using the Conceptual Graph. Journal of Information Technology in Construction, 21:371-403, 2016. ISSN 1874-4753.

[170] T H Beach, Y Rezgui, H Li, and T Kasim. A rule-based semantic approach for automated regulatory compliance in the construction sector. Expert Systems with Applications, 42(12):5219-5231, 2015. doi: 10.1016/j.eswa.2015.02.029.

[171] Soft Tech. CivitPERMIT description, 2021. URL https://thecivit.com/product-civitpermit/.

[172] Alberto Alli and Marco Rognoni. Automated Code Checking in the Epermit BIM Process. In DIGITAL BUILDING PERMIT:A STATE OF PLAY. I EUnet4DBP International workshop on Digital Building Permit. EuroSDR, 2021.

\section{Appendix A. The detailed classification of reviewed documents}

In this appendix, Table A.5-A.12 are reported showing the complete classification of the analyzed documents, divided per steps.

\begin{tabular}{|c|c|c|c|c|c|c|}
\hline \multicolumn{7}{|c|}{ Step 1} \\
\hline Entry & Description & AR & AA & KoC & Progress & Country \\
\hline $\begin{array}{l}\text { Van Berlo } \\
\text { et al. [71] } \\
\text { (2013) }\end{array}$ & $\begin{array}{l}\text { Proposes the storage of spatial planning } \\
\text { information in 3D based on CityGML and } \\
\text { the Dutch zoning data. It is also proposed } \\
\text { the conversion of such a dataset to IFC by } \\
\text { means of FZK viewer. }\end{array}$ & $\begin{array}{l}\text { r3, r4, } \\
\text { r5 }\end{array}$ & R1 & A2 & Executing & $\begin{array}{l}\text { The } \\
\text { Nether- } \\
\text { lands }\end{array}$ \\
\hline $\begin{array}{l}\text { Macit } \\
\text { İlal and } \\
\text { Günaydın } \\
{[74]} \\
\text { (2017) }\end{array}$ & $\begin{array}{l}\text { Method to formalize and code building reg- } \\
\text { ulations. }\end{array}$ & $\mathrm{r} 4$ & R1 & B1 & Closing & Turkey/Int \\
\hline $\begin{array}{l}\text { Lee } \\
\text { et al. [83] } \\
\text { (2015) }\end{array}$ & $\begin{array}{l}\text { Develops a software that allows users to } \\
\text { export selected rules in building codes } \\
\text { as computer-readable format by benefiting } \\
\text { from created database. The classification } \\
\text { of texts in building code is done manually. }\end{array}$ & r4 & $\mathrm{R} 1, \mathrm{~T} 3$ & B1 & Executing & $\begin{array}{l}\text { South Ko- } \\
\text { rea }\end{array}$ \\
\hline $\begin{array}{l}\text { Beach and } \\
\text { Rezgui } \\
\text { [72] } \\
(2018)\end{array}$ & $\begin{array}{l}\text { Proposes an approach that allows to en- } \\
\text { code building regulations into executable } \\
\text { format using RASE strategy and ifcOWL. }\end{array}$ & r4 & $\mathrm{R} 1, \mathrm{R} 2$ & B1 & Executing & UK/Int \\
\hline
\end{tabular}




\begin{tabular}{|c|c|c|c|c|c|c|}
\hline $\begin{array}{l}\text { Zhang and } \\
\text { El-Gohary } \\
{[75]} \\
(2016)\end{array}$ & $\begin{array}{l}\text { Propose a new method, based on seman- } \\
\text { tic natural language processing (NLP) tech- } \\
\text { niques and machine learning techniques, } \\
\text { for extending the IFC schema to incorpo- } \\
\text { rate Compliance Checking-related informa- } \\
\text { tion, in an objective and semi-automated } \\
\text { manner. }\end{array}$ & $r 4, r 11$ & T3 & $\mathrm{A} 2$ & Closing & USA \\
\hline $\begin{array}{l}\text { Song } \\
\text { et al. [76] } \\
(2018)\end{array}$ & $\begin{array}{l}\text { Natural Language Processing to interpret } \\
\text { and formalize regulations }\end{array}$ & r3, r4 & $\mathrm{R} 1$ & B1 & Executing & $\begin{array}{l}\text { South Ko- } \\
\text { rea }\end{array}$ \\
\hline $\begin{array}{l}\text { Song } \\
\text { et al. [79] } \\
(2019)\end{array}$ & $\begin{array}{l}\text { Describes the KBimCode translator, which } \\
\text { translates KBimCode into an executable } \\
\text { code of specific rule checking software, } \\
\text { named KBimAssess. }\end{array}$ & r4 & $\mathrm{R} 2, \mathrm{~T} 3$ & B1 & Executing & $\begin{array}{l}\text { South Ko- } \\
\text { rea }\end{array}$ \\
\hline $\begin{array}{l}\text { Nisbet } \\
\text { et al. [73] } \\
(2009)\end{array}$ & $\begin{array}{l}\text { Require } 1 \text { is a tool that support the coding } \\
\text { analysis of Building Regulations based on } \\
\text { the RASE methodology. }\end{array}$ & $\begin{array}{l}r 3, \quad r 4, \\
r 8, \quad r 9 \\
r 11\end{array}$ & $\begin{array}{l}\text { E1, } \\
\text { P1, } \\
\text { P2, } \\
\text { R1, R2 }\end{array}$ & B2 & Validating & UK, USA \\
\hline $\begin{array}{l}\text { Park } \\
\text { et al. [80] } \\
(2016)\end{array}$ & $\begin{array}{l}\text { Describes the definition of KBimCode Lan- } \\
\text { guage and demonstrates its actual use } \\
\text { case. }\end{array}$ & r4. & R2, T3 & B1 & Executing & $\begin{array}{l}\text { South Ko- } \\
\text { rea }\end{array}$ \\
\hline $\begin{array}{l}\text { Park and } \\
\text { Lee }[81] \\
(2016)\end{array}$ & $\begin{array}{l}\text { Explains the KBimCode used as a base for } \\
\text { checking compliance to regulations in BIM. }\end{array}$ & r4 & $\mathrm{R} 2$ & B1 & Closing & $\begin{array}{l}\text { South Ko- } \\
\text { rea }\end{array}$ \\
\hline $\begin{array}{l}\text { Kim } \\
\text { et al. [82] } \\
(2017)\end{array}$ & $\begin{array}{l}\text { Classifies objects and properties in regu- } \\
\text { lations related to building permit from the } \\
\text { Korean Building Act and adds them to a } \\
\text { object-name database to facilitate later use } \\
\text { in KBimCode. }\end{array}$ & $\mathrm{r} 4, \mathrm{r} 9$ & $\mathrm{R} 1, \mathrm{R} 2$ & B1 & Closing & $\begin{array}{l}\text { South Ko- } \\
\text { rea }\end{array}$ \\
\hline $\begin{array}{l}\text { Lee } \\
\text { et al. [12] } \\
(2016)\end{array}$ & $\begin{array}{l}\text { The paper describes a translation of the Ko- } \\
\text { rean building act into a computer-readable } \\
\text { language. }\end{array}$ & r3, r4 & $\mathrm{R} 1, \mathrm{~T} 1$ & A2 & Executing & $\begin{array}{l}\text { South Ko- } \\
\text { rea }\end{array}$ \\
\hline $\begin{array}{l}\text { Zhang and } \\
\text { El-Gohary } \\
{[77]} \\
(2017)\end{array}$ & $\begin{array}{l}\text { Develops an integrated system that trans- } \\
\text { forms building codes into logic rules using } \\
\text { NLP and allows for automatic checking of } \\
\text { these rules by using EXPRESS data. }\end{array}$ & r4 & T3 & B1 & Validating & USA/Int \\
\hline $\begin{array}{l}\text { Zhang and } \\
\text { El-Gohary } \\
{[78]} \\
(2020)\end{array}$ & $\begin{array}{l}\text { Proposes a machine learning-based ap- } \\
\text { proach to automatically match the building- } \\
\text { code concepts and relations to their equiv- } \\
\text { alent concepts and relations in the Industry } \\
\text { Foundation Classes (IFC). }\end{array}$ & r4 & R1 & B1 & Executing & USA \\
\hline $\begin{array}{l}\text { Noardo } \\
\text { et al. [70] } \\
(2020)\end{array}$ & $\begin{array}{l}\text { Explores the building permit use case in } \\
\text { collaboration with the municipality of Rot- } \\
\text { terdam. The interpretation and formaliza- } \\
\text { tion of regulation for building height, over- } \\
\text { hang and tower ratio is proposed as prelim- } \\
\text { inary results. }\end{array}$ & $\begin{array}{l}\text { r3, r9, } \\
\text { r10 }\end{array}$ & T3 & B1 & Executing & $\begin{array}{l}\text { The } \\
\text { Nether- } \\
\text { lands }\end{array}$ \\
\hline $\begin{array}{l}\text { Nawari } \\
{[84]} \\
(2012)\end{array}$ & $\begin{array}{l}\text { Examines the challenges in the computer- } \\
\text { readable representation of building codes } \\
\text { and standards to link them to BIM. }\end{array}$ & r4 & $\mathrm{R} 1$ & $\mathrm{~A} 1$ & $\begin{array}{l}\text { Conception } \\
\text { and Initia- } \\
\text { tion }\end{array}$ & Int \\
\hline
\end{tabular}

Table A.5: Classification of contributions related to the Step 1, i.e., rule interpretation and digitalization of city and building regulations. (AR: Addressed Requirement, AA: Addressed Ambition, KoC: Kind of Contribution)

\begin{tabular}{|c|c|c|c|c|c|c|}
\hline \multicolumn{7}{|c|}{ Step 2} \\
\hline Entry & Description & AR & AA & KoC & Progress & Country \\
\hline $\begin{array}{l}\text { Trdla [163] } \\
\text { (2021) }\end{array}$ & $\begin{array}{l}\text { The Central Repository of the Liberec Re- } \\
\text { gion. The building will be as a storage of } \\
\text { museum collections ensuring optimal con- } \\
\text { ditions. The building holds up to hundreds } \\
\text { of thousands of subjects, which are needed } \\
\text { thousands of square meters. }\end{array}$ & $\begin{array}{l}r 1, \quad r 5, \\
r 6, r 10, \\
r 11\end{array}$ & $\begin{array}{l}\text { E1, } \\
\text { P1, } \\
\text { R1, T2 }\end{array}$ & B1 & $\begin{array}{l}\text { Definition } \\
\text { and Plan- } \\
\text { ning }\end{array}$ & $\begin{array}{l}\text { Czech re- } \\
\text { public }\end{array}$ \\
\hline
\end{tabular}




\begin{tabular}{|c|c|c|c|c|c|c|}
\hline $\begin{array}{l}\text { Eriksson } \\
\text { et al. [85] } \\
(2020)\end{array}$ & $\begin{array}{l}\text { Creates a proposal for a national Swedish } \\
\text { 3D city building standard as a CityGML } 3.0 \\
\text { ADE. A prototype was developed where ex- } \\
\text { isting 3D buildings (dwg-format) and a de- } \\
\text { tailed development plan were imported be- } \\
\text { fore an automated check of three building } \\
\text { permit regulations was performed. }\end{array}$ & $\mathrm{r} 8, \mathrm{r} 10$ & T3 & B1 & Validating & Sweden \\
\hline $\begin{array}{l}\text { Limsupreeya } \\
\text { et al. [164] } \\
(2017)\end{array}$ & $\begin{array}{l}\text { Develops a prototype expert system for } \\
\text { rahecking land uses designations before } \\
\text { submitting building construction permits. } \\
\text { The prototype integrates regulations, GIS } \\
\text { database and Google Maps. }\end{array}$ & r1 & $\begin{array}{l}\text { E1, } \\
\text { P1, T2 }\end{array}$ & B1 & Executing & Thailand \\
\hline $\begin{array}{l}\text { Alterkawi } \\
{[43]} \\
(2005)\end{array}$ & $\begin{array}{l}\text { Investigates the use of GIS in the admin- } \\
\text { istration of building permits and defines the } \\
\text { functional specifications, the specific needs } \\
\text { and requirements of the Building Permits } \\
\text { Section within the Riyadh city system. }\end{array}$ & r5 & $\mathrm{T} 2$ & C & $\begin{array}{l}\text { Definition } \\
\text { and Plan- } \\
\text { ning }\end{array}$ & $\begin{array}{l}\text { Saudi Ara- } \\
\text { bia }\end{array}$ \\
\hline $\begin{array}{l}\text { Chognard } \\
\text { et al. [87] } \\
(2018)\end{array}$ & $\begin{array}{l}\text { Proposes a three-step translation protocol } \\
\text { in order to transform data from GIS into an } \\
\text { IFC reference environment model. }\end{array}$ & $\mathrm{r} 5, \mathrm{r} 11$ & T3 & B1 & Executing & Switzerland \\
\hline $\begin{array}{l}\text { Salheb } \\
\text { et al. [86] } \\
(2020)\end{array}$ & $\begin{array}{l}\text { Proposes a conversion tool from CityGML } \\
\text { v. } 2 \text { to IFC, also as a reference for building } \\
\text { design }\end{array}$ & r5 & T3 & B1 & Executing & $\begin{array}{l}\text { The } \\
\text { Nether- } \\
\text { lands }\end{array}$ \\
\hline $\begin{array}{l}\text { Clemen } \\
\text { et al. [88] } \\
(2021)\end{array}$ & $\begin{array}{l}\text { Proposes a Revit API to convert use- } \\
\text { ful geoinformation, including properties } \\
\text { and restrictions, (GML application schema, } \\
\text { CityGML, CAD/DXF) to BIM as a reference } \\
\text { for design. }\end{array}$ & r5 & T3 & B1 & Executing & Germany \\
\hline $\begin{array}{l}\text { Mandrile } \\
{[165]} \\
(2020)\end{array}$ & $\begin{array}{l}\text { BIM A+ Master thesis, a CityGML model } \\
\text { (modelled from the further geoinformation } \\
\text { available) is used, with Energy ADE, as a } \\
\text { base for building environment analysis. }\end{array}$ & r5 & T3 & $\mathrm{A} 2$ & Executing & $\begin{array}{l}\text { Slovenia, } \\
\text { Portugal }\end{array}$ \\
\hline $\begin{array}{l}\text { Guler and } \\
\text { Yomrali- } \\
\text { oglu [34] } \\
(2021)\end{array}$ & $\begin{array}{l}\text { Besides a reformative framework for build- } \\
\text { ing permit procedures in Turkey, the paper } \\
\text { proposes a review of available standards } \\
\text { for representing 3D city models and geoin- } \\
\text { formation for DBPs. }\end{array}$ & $r 1, r 5$ & $\mathrm{P} 1$ & $\mathrm{~A} 2$ & $\begin{array}{l}\text { Definition } \\
\text { and Plan- } \\
\text { ning }\end{array}$ & Turkey \\
\hline
\end{tabular}

Table A.6: Classification of contributions related to the Step 2, i.e., the modelling and use of $3 d$ city models and geoinformation as input for DBPs.

\begin{tabular}{|c|c|c|c|c|c|c|}
\hline \multicolumn{7}{|c|}{ Step 3} \\
\hline Entry & Description & AR & $\overline{\text { AA }}$ & KoC & Progress & Country \\
\hline $\begin{array}{l}\text { Dimyadi } \\
\text { et al. [89] } \\
(2016)\end{array}$ & $\begin{array}{l}\text { Proposal of a method to code requirements } \\
\text { for BIM/IFC designers to support automatic } \\
\text { compliance checks }\end{array}$ & $r 4, r 10$ & $\mathrm{R} 1, \mathrm{R} 2$ & B1 & $\begin{array}{l}\text { Definition } \\
\text { and plan- } \\
\text { ning }\end{array}$ & Australia/Int \\
\hline $\begin{array}{l}\text { Urbanismo } \\
\text { sual [95] } \\
(2020)\end{array}$ & $\begin{array}{l}\text { VisualUrb is a new software that has ap- } \\
\text { /i-peared in Spanish market to support de- } \\
\text { signers in the initial analysis of a project } \\
\text { thanks to the providing the existing and } \\
\text { available plots of the whole country. }\end{array}$ & $\begin{array}{l}r 1, r 3, \\
r 4, r 5\end{array}$ & $\begin{array}{l}\mathrm{E} 1 \\
\mathrm{P} 1 \\
\mathrm{R} 1, \mathrm{~T} 3\end{array}$ & C & Closing & Spain \\
\hline $\begin{array}{l}\text { Nisbet } \\
\text { et al. [73] } \\
(2009)\end{array}$ & $\begin{array}{l}\text { Regulation texts can be marked up us- } \\
\text { ing the RASE methodology to identify the } \\
\text { logical structure and the logical metrics. } \\
\text { (micro-queries). }\end{array}$ & $\begin{array}{l}\text { r2, r3, } \\
\text { r4 }\end{array}$ & $\begin{array}{l}\text { T1, T2, } \\
\text { R1, R2 }\end{array}$ & B2 & Validating & UK, USA \\
\hline
\end{tabular}




\begin{tabular}{|c|c|c|c|c|c|c|}
\hline $\begin{array}{l}\text { Boverket } \\
{[96]} \\
(2020)\end{array}$ & $\begin{array}{l}\text { Boverket is a prototype where an applicant } \\
\text { can select a single family house and place } \\
\text { it in a desired location to check some regu- } \\
\text { lations related to the building permit: build- } \\
\text { ing area, building height, max rood height. } \\
\text { The service helps the applicant check if a } \\
\text { building is allowed at a specific location al- } \\
\text { ready before submitting the building permit } \\
\text { application. }\end{array}$ & r5 & T3 & B1 & Closing & Sweden \\
\hline $\begin{array}{l}\text { Kim } \\
\text { et al. [90] } \\
(2017)\end{array}$ & $\begin{array}{l}\text { Describes the development of rule-based } \\
\text { platform to query building elements through } \\
\text { the connection with a database of design } \\
\text { guidelines, international standards and na- } \\
\text { tional acts in computer-readable formats }\end{array}$ & r4 & T3 & B2 & Executing & $\begin{array}{l}\text { South Ko- } \\
\text { rea }\end{array}$ \\
\hline $\begin{array}{l}\text { Nguyen } \\
\text { and } \\
\text { Kim }[93] \\
(2011)\end{array}$ & $\begin{array}{l}\text { They propose a "building design frame- } \\
\text { work" to allow tracking compliance of the } \\
\text { design in Revit. }\end{array}$ & $r 4, r 11$ & T3 & B1 & Executing & USA \\
\hline $\begin{array}{l}\text { Demir } \\
\text { Altıntaş } \\
\text { and } \\
\text { llal [92] } \\
(2021)\end{array}$ & $\begin{array}{l}\text { Analyzes building code to identify required } \\
\text { neighbourhood (spatial) data for automated } \\
\text { code checking. A list of zoning concepts is } \\
\text { created. } 30 \% \text { of the zoning concept could } \\
\text { be modelled in IFC, all could be modelled in } \\
\text { GIS (GML). BIM and GIS models were cre- } \\
\text { ated and coupled in a unified environment } \\
\text { and the automated code compliance check } \\
\text { was performed. Only 2D data included. }\end{array}$ & $\begin{array}{l}r 4, r 5, \\
r 11\end{array}$ & T3 & $\mathrm{A} 2$ & Validating & Turkey \\
\hline $\begin{array}{l}\text { Krijnen } \\
\text { and Van } \\
\text { Berlo } \\
{[166]} \\
(2016)\end{array}$ & $\begin{array}{l}\text { A general overview of technologies for re- } \\
\text { quirement checking on building (IFC) mod- } \\
\text { els. Describes how one example require- } \\
\text { ment can be formalized and queries an } \\
\text { IFC-model as a demonstration. }\end{array}$ & $r 3, r 11$ & T3 & $\mathrm{A} 2$ & $\begin{array}{l}\text { Conception } \\
\text { and Initia- } \\
\text { tion }\end{array}$ & $\begin{array}{l}\text { The } \\
\text { Nether- } \\
\text { lands }\end{array}$ \\
\hline $\begin{array}{l}\text { Van Berlo } \\
\text { et al. [71] } \\
(2013)\end{array}$ & $\begin{array}{l}\text { Proposes the spatial encoding and storage } \\
\text { of Dutch zoning data, which can be more } \\
\text { precise reference also for pre-consultation. }\end{array}$ & $\begin{array}{l}r 3, r 4, \\
r 5, r 11\end{array}$ & $\mathrm{R} 1, \mathrm{~T} 3$ & $\mathrm{~A} 2$ & Executing & $\begin{array}{l}\text { The } \\
\text { Nether- } \\
\text { lands }\end{array}$ \\
\hline $\begin{array}{l}\text { Kincelova } \\
\text { et al. [91] } \\
(2020)\end{array}$ & $\begin{array}{l}\text { Developes a Dynamo script that automat- } \\
\text { ically checks regulations related to fire } \\
\text { safety in the Canadian context. }\end{array}$ & $\mathrm{r} 4, \mathrm{r} 11$ & $\mathrm{R} 1, \mathrm{~T} 3$ & B1 & Validating & Canada \\
\hline $\begin{array}{l}\text { Shahi } \\
\text { et al. [13] } \\
(2019)\end{array}$ & $\begin{array}{l}\text { Defines three distinct levels of e-permitting } \\
\text { varying in levels of automation and inte- } \\
\text { gration based on recent international de- } \\
\text { velopments towards the replacement of } \\
\text { paper-based practices. Further it includes } \\
\text { a framework that considers the impact of } \\
\text { each level (Level } 0-3 \text { ) of e-permitting on the } \\
\text { entire lifecycle of the project. }\end{array}$ & $\begin{array}{l}r 1, r 6, \\
r 9\end{array}$ & $\begin{array}{l}\text { E1, } \\
\text { T2, T3 }\end{array}$ & $\mathrm{A} 2$ & $\begin{array}{l}\text { Definition } \\
\text { and Plan- } \\
\text { ning }\end{array}$ & Canada \\
\hline
\end{tabular}

Table A.7: Classification of contributions related to the Step 3, i.e., 'Preconsultation and preliminary analysis'

\begin{tabular}{|l|l|l|l|l|l|l|}
\hline \multicolumn{9}{|c|}{ Step 4 } & AR & AA & KoC & Progress & Country \\
\hline Entry & Description & & & & \\
\hline & $\begin{array}{l}\text { For current BIM to achieve the necessary } \\
\text { information for automatic code compliance } \\
\text { checks (w.r.t. several regulation types), se- } \\
\text { Bloch and } \\
\text { Sacks [99] } \\
\text { (2020) }\end{array}$ & $\begin{array}{l}\text { ing is proposed. The categories of seman- } \\
\text { tic enrichment tasks are defined, starting } \\
\text { from the analysis of the codes and current } \\
\text { IFC MVDs. }\end{array}$ & R2 & A2 & Executing & Israel/Int \\
\hline $\begin{array}{l}\text { Solihin } \\
\text { et al. [101] } \\
\text { (2004) }\end{array}$ & $\begin{array}{l}\text { The platform FORNAX applies the neces- } \\
\text { sary inferences to the IFC model in order } \\
\text { to get the information necessary to check } \\
\text { some aspects of the building codes. }\end{array}$ & r10 & T3 & A2 & Executing & Singapore/ \\
Int
\end{tabular}




\begin{tabular}{|c|c|c|c|c|c|c|}
\hline $\begin{array}{l}\text { van Berlo } \\
\text { and Pa- } \\
\text { padoniko- } \\
\text { laki [104] } \\
(2016)\end{array}$ & $\begin{array}{l}\text { Preliminary insight into the readiness of } \\
\text { IFC models w.r.t. established require- } \\
\text { ments. Proposes to validate each disci- } \\
\text { plinary BIM before the upload to coordi- } \\
\text { nated BIM }\end{array}$ & $\mathrm{r} 10$ & $\mathrm{R} 2$ & $\mathrm{~A} 2$ & $\begin{array}{l}\text { Conception } \\
\text { and initia- } \\
\text { tion }\end{array}$ & $\begin{array}{l}\text { The } \\
\text { Nether- } \\
\text { lands }\end{array}$ \\
\hline $\begin{array}{l}\text { Lee et al. } \\
{[100]} \\
(2018)\end{array}$ & $\begin{array}{l}\text { An IFC MVDs is proposed to provide clear } \\
\text { data requirements to BIM modellers (sup- } \\
\text { porting also IFC validation) }\end{array}$ & r10 & $\mathrm{R} 2$ & B1 & Executing & USA \\
\hline $\begin{array}{l}\text { Kouba and } \\
\text { Masák } \\
{[103]} \\
(2020)\end{array}$ & $\begin{array}{l}\text { The scope of the project is to define the } \\
\text { uses of BIM in the design process and to } \\
\text { establish a guideline for the export of "stan- } \\
\text { dard" documentation for the building permit } \\
\text { use case, as well as to set the specifica- } \\
\text { tions of the building model from the design } \\
\text { stage to be used for tendering the construc- } \\
\text { tion company. }\end{array}$ & $\begin{array}{l}r 4, \quad r 5 \\
r 6, r 10\end{array}$ & $\mathrm{P} 1, \mathrm{R} 2$ & C & Executing & $\begin{array}{l}\text { Czech Re- } \\
\text { public }\end{array}$ \\
\hline $\begin{array}{l}\text { Estonia } \\
\text { Ministry of } \\
\text { Economic } \\
\text { Affairs \& } \\
\text { Commu- } \\
\text { nications } \\
{[102]} \\
(2021)\end{array}$ & $\begin{array}{l}\text { Development of the Estonian BIM-based } \\
\text { building permit process formalizing the so } \\
\text { called Public Sector BIM requirements, an } \\
\text { additional data-set required for the input of } \\
\text { the process where the data content of BIM } \\
\text { models is expressed IFC format and a com- } \\
\text { mon classification, the CCI-EE system, is } \\
\text { used. }\end{array}$ & r6, r10 & $\begin{array}{l}\mathrm{P} 1, \\
\mathrm{R} 1, \mathrm{R} 2\end{array}$ & B1 & Executing & Estonia \\
\hline $\begin{array}{l}\text { Malsane } \\
\text { et al. [20] } \\
(2015)\end{array}$ & $\begin{array}{l}\text { Develops an IFC-based, building } \\
\text { regulation-specific and semantically } \\
\text { rich object model, appropriate for the } \\
\text { requirements of automated compliance } \\
\text { checking for England and Wales fire safety } \\
\text { regulations }\end{array}$ & $\begin{array}{l}r 10, \\
r 11\end{array}$ & T3 & $\mathrm{A} 2$ & Validating & $\begin{array}{l}\text { UK, Aus- } \\
\text { tralia }\end{array}$ \\
\hline $\begin{array}{l}\text { Narayanswar } \\
\text { et al. [6] } \\
(2019)\end{array}$ & $\begin{array}{l}\text { C sharp language has been used to create } \\
\text { model view and to extract building infor- } \\
\text { mation for light-frame building compliance } \\
\text { checking from the BIM solution, Autodesk } \\
\text { Revit. }\end{array}$ & $\begin{array}{l}r 4, \quad r 5, \\
r 6\end{array}$ & $\mathrm{P} 1$ & $\mathrm{~A} 2$ & Executing & $\begin{array}{l}\text { USA, } \\
\text { Canada }\end{array}$ \\
\hline $\begin{array}{l}\text { Preidel } \\
\text { and Bor- } \\
\text { rmann } \\
{[167]} \\
(2015)\end{array}$ & $\begin{array}{l}\text { Proposal of concept of 'Visual Code Check- } \\
\text { ing Language". Pilot application to the Ger- } \\
\text { man fire code. }\end{array}$ & r4 & P1, T3 & $\mathrm{A} 2$ & $\begin{array}{l}\text { Definition } \\
\text { and plan- } \\
\text { ning }\end{array}$ & Germany \\
\hline $\begin{array}{l}\text { Greenwood } \\
\text { et al. [9] } \\
(2010)\end{array}$ & $\begin{array}{l}\text { Literature review and discussion on advan- } \\
\text { tages and challenges for automatic compli- } \\
\text { ance checking using BIM, providing focus } \\
\text { on the importance of IFC. }\end{array}$ & $\begin{array}{l}r 2, r 6, \\
\text { r10 }\end{array}$ & P1, T3 & $\mathrm{A} 1$ & $\begin{array}{l}\text { Definition } \\
\text { and Plan- } \\
\text { ning }\end{array}$ & UK \\
\hline $\begin{array}{l}\text { Zhou and } \\
\text { El-Gohary } \\
\text { [98] } \\
(2018)\end{array}$ & $\begin{array}{l}\text { After having used Natural Language Pro- } \\
\text { cessing to extract the semantics from the } \\
\text { regulations, a semantic matching method is } \\
\text { proposed to extract from the BIM (in IFC) } \\
\text { the information necessary to check the en- } \\
\text { ergy regulations. }\end{array}$ & $\mathrm{r} 10$ & T3 & $\mathrm{A} 2$ & Executing & USA \\
\hline $\begin{array}{l}\text { Zhou and } \\
\text { El-Gohary } \\
{[122]} \\
(2019)\end{array}$ & $\begin{array}{l}\text { Proposes a set of text and information an- } \\
\text { alytics methods for fully automated compli- } \\
\text { ance checking of BIMs with energy codes. } \\
\text { Work is IFC-based }\end{array}$ & r3 & $\mathrm{R} 2$ & $\mathrm{~A} 2$ & Executing & USA \\
\hline $\begin{array}{l}\text { Song } \\
\text { et al. [134] } \\
(2020)\end{array}$ & $\begin{array}{l}\text { Describes an approach to extracting a } \\
\text { predicate-argument structure in building } \\
\text { design rule sentences using natural lan- } \\
\text { guage processing and deep learning mod- } \\
\text { els. }\end{array}$ & r4 & $\mathrm{R} 2$ & $\mathrm{~A} 2$ & Executing & $\begin{array}{l}\text { South Ko- } \\
\text { rea }\end{array}$ \\
\hline
\end{tabular}

Table A.8: Classification of contributions related to the Step 4, i.e., BIM and export to IFC. 


\begin{tabular}{|c|c|c|c|c|c|c|}
\hline Entry & Description & AR & AA & KoC & Progress & Country \\
\hline $\begin{array}{l}\text { Moult and } \\
\text { Krijnen } \\
{[112]} \\
(2020)\end{array}$ & $\begin{array}{l}\text { In BlenderBIM Add-on, the data require- } \\
\text { ments expressed in Python implementa- } \\
\text { tion IfcOpenShell through the Gherkin lan- } \\
\text { guage can be used to check IFC models } \\
\text { validity. }\end{array}$ & $\begin{array}{l}r 3, \quad r 4, \\
\text { r10 }\end{array}$ & $\begin{array}{l}\text { R1, } \\
\text { R2, T3 }\end{array}$ & B2 & Validating & $\begin{array}{l}\text { Australia/ } \\
\text { Int }\end{array}$ \\
\hline $\begin{array}{l}\text { Choi and } \\
\text { Kim }[109] \\
(2017)\end{array}$ & $\begin{array}{l}\text { Develops a multipartite, web-based system } \\
\text { that enables automatically checking of the } \\
\text { design quality of the buildings based on IFC } \\
\text { data. }\end{array}$ & r10 & $\begin{array}{l}\text { R2, } \\
\text { T2, T3 }\end{array}$ & B1 & Validating & Korea \\
\hline $\begin{array}{l}\text { Bus et al. } \\
{[110]} \\
(2018)\end{array}$ & $\begin{array}{l}\text { Proposes an approach that contains the } \\
\text { conversion of IFC files to RDF and then } \\
\text { checks the compliance of these files using } \\
\text { SPARQL. }\end{array}$ & r4 & T3 & B1 & $\begin{array}{l}\text { Conception } \\
\text { and Initia- } \\
\text { tion }\end{array}$ & France \\
\hline $\begin{array}{l}\text { TNO [168] } \\
(2018)\end{array}$ & $\begin{array}{l}\text { Automatic check of code delivery specifica- } \\
\text { tions (CDS) based on the BIM Bots tech- } \\
\text { nology. The BIM Bots technology is under } \\
\text { development. }\end{array}$ & r2, r11 & $\mathrm{P} 1$ & B1 & $\begin{array}{l}\text { Conception } \\
\text { and Initia- } \\
\text { tion }\end{array}$ & $\begin{array}{l}\text { The } \\
\text { Nether- } \\
\text { lands/ } \\
\text { National / } \\
\text { Int }\end{array}$ \\
\hline $\begin{array}{l}\text { Johansson } \\
{[105]} \\
(2020)\end{array}$ & $\begin{array}{l}\text { Develops specifications to support an un- } \\
\text { broken digital data flow in the building per- } \\
\text { mit process.A simple prototype to check if a } \\
\text { IFC-file follows a few rules to facilitate con- } \\
\text { version from Ifc }\end{array}$ & r8 & T3 & B1 & Closing & Sweden \\
\hline $\begin{array}{l}\text { Narayanswa } \\
\text { et al. [6] } \\
(2019)\end{array}$ & $\begin{array}{l}\text { Develops in C sharp an add-on software } \\
\text { nypplication for automated design checking } \\
\text { (i.e., DCheck) using Autodesk Revit API for } \\
\text { light-frame buildings. }\end{array}$ & $\begin{array}{l}r 4, \quad r 5, \\
r 6\end{array}$ & P1 & B1 & Executing & $\begin{array}{l}\text { USA, } \\
\text { Canada }\end{array}$ \\
\hline $\begin{array}{l}\text { Lee et al. } \\
{[100]} \\
(2018)\end{array}$ & $\begin{array}{l}\text { Proposes a method to validate IFC models } \\
\text { according to MVDs. The authors describe } \\
\text { the rule logic behind the validation and im- } \\
\text { plements a demonstrator based on the Ifc- } \\
\text { Doc tool (buildingSMART). }\end{array}$ & $\begin{array}{l}\text { r10, } \\
\text { r11 }\end{array}$ & T3 & B1 & Executing & USA \\
\hline $\begin{array}{l}\text { van Berlo } \\
\text { and Pa- } \\
\text { padoniko- } \\
\text { laki [104] } \\
(2016)\end{array}$ & $\begin{array}{l}\text { Proposes the check of some Dutch regula- } \\
\text { tions by means of GeoBIM integration and } \\
\text { conversion of regulation data into spatial } \\
\text { format (IFC) and discusses the experiment }\end{array}$ & $r 11$ & T3 & $\mathrm{A} 2$ & Closing & $\begin{array}{l}\text { The } \\
\text { Nether- } \\
\text { lands }\end{array}$ \\
\hline $\begin{array}{l}\text { Zhang and } \\
\text { El-Gohary } \\
{[107]} \\
(2015)\end{array}$ & $\begin{array}{l}\text { Develops an integrated system that trans- } \\
\text { forms building codes into logic rules using } \\
\text { NLP and allow for automatic checking of } \\
\text { these rules by using EXPRESS data }\end{array}$ & r4 & T3 & B1 & Validating & USA \\
\hline $\begin{array}{l}\text { Zhang and } \\
\text { El-Gohary } \\
{[106]} \\
(2015)\end{array}$ & $\begin{array}{l}\text { Propose an automated method for ex- } \\
\text { tracting design information from IFC-based } \\
\text { BIMs into a semantic logic-based represen- } \\
\text { tation using semantic natural language pro- } \\
\text { cessing (NLP) techniques and java stan- } \\
\text { dard data access interface (JSDAI). }\end{array}$ & $r 3, r 11$ & T3 & $\mathrm{A} 2$ & Closing & USA \\
\hline $\begin{array}{l}\text { Ciribini } \\
\text { et al. [108] } \\
(2016)\end{array}$ & $\begin{array}{l}\text { Applies a model checker to validate the in- } \\
\text { formative content of BIM models as a pre- } \\
\text { liminary activity for BIM-based code check- } \\
\text { ing. }\end{array}$ & $r 11$ & T3 & B2 & $\begin{array}{l}\text { Definition } \\
\text { and plan- } \\
\text { ning }\end{array}$ & Italy \\
\hline $\begin{array}{l}\text { Ghannad } \\
\text { et al. [113] } \\
(2019)\end{array}$ & $\begin{array}{l}\text { Proposes a new modularized framework } \\
\text { that integrates an emerging open standard } \\
\text { with a VPL. The framework allows a stan- } \\
\text { dardized method of defining design rules in } \\
\text { a machine-readable and executable format. } \\
\text { It is expected to help automatically and it- } \\
\text { eratively evaluate the level of quality and } \\
\text { defects of information conveyed in a given } \\
\text { building model. }\end{array}$ & $\begin{array}{l}r 4, r 5 \\
r 8, r 11\end{array}$ & $\mathrm{R} 1, \mathrm{R} 2$ & $\mathrm{~A} 2$ & Executing & USA \\
\hline
\end{tabular}




\begin{tabular}{|c|c|c|c|c|c|c|}
\hline $\begin{array}{l}\text { Preidel } \\
\text { and Bor- } \\
\text { rmann [97] } \\
(2015)\end{array}$ & $\begin{array}{l}\text { Introduces a method which enables auto- } \\
\text { mated code checking using a flow-based, } \\
\text { VPL and demonstrates the practical imple- } \\
\text { mentation of a semi-automated compliance } \\
\text { check approach concerning an exemplary } \\
\text { German fire code. }\end{array}$ & $r 11$ & P1, T3 & B1 & Validating & Germany \\
\hline $\begin{array}{l}\text { Fahad and } \\
\text { Bus [111] } \\
\text { (2019) }\end{array}$ & $\begin{array}{l}\text { Proposes a research prototype that en- } \\
\text { ables to check the IFC models against the } \\
\text { building codes using SPARQL queries. }\end{array}$ & r4 & R1, T3 & $\mathrm{A} 2$ & Executing & France \\
\hline
\end{tabular}

Table A.9: Classification of contributions related to the Step 5, i.e., Appli-

cation reviewed (formal requirements - data validation).

\begin{tabular}{|c|c|c|c|c|c|c|}
\hline \multicolumn{7}{|c|}{ Step 6} \\
\hline Entry & Description & AR & $\overline{A A}$ & KoC & Progress & Country \\
\hline $\begin{array}{l}\text { Olsson } \\
\text { et al. [114] } \\
(2018)\end{array}$ & $\begin{array}{l}\text { The conversion of IFC data to geo-format } \\
\text { (CityGML) is performed by means of Safe } \\
\text { software FME scripts in order to allow } \\
\text { checks based on the building context. }\end{array}$ & $\begin{array}{l}r 10, \\
r 11\end{array}$ & T3 & A2 & Validating & Sweden \\
\hline $\begin{array}{l}\text { Eriksson } \\
\text { et al. [85] } \\
(2020)\end{array}$ & $\begin{array}{l}\text { Creates a proposal for a national Swedish } \\
\text { 3D city building standard as a CityGML } 3.0 \\
\text { ADE. Test data were created by converting } \\
\text { an IFC model to the national CityGML } 3.0 \\
\text { ADE to demonstrate how a 3D city model } \\
\text { can be updated. }\end{array}$ & r8, r10 & T3 & B1 & Validating & Sweden \\
\hline $\begin{array}{l}\text { City of } \\
\text { Järvenpää } \\
{[116]} \\
(2021)\end{array}$ & $\begin{array}{l}\text { Testing an IFC model as part of the existing } \\
\text { city model. }\end{array}$ & r5 & $\mathrm{P} 1$ & C & Closing & Finland \\
\hline $\begin{array}{l}\text { Johansson } \\
{[105]} \\
(2020)\end{array}$ & $\begin{array}{l}\text { BIM data (IFC) was converted to 3D geo- } \\
\text { data in order to enable automated building } \\
\text { permitting as part of a project looking at de- } \\
\text { livery specifications to facilitate an unbro- } \\
\text { ken digital data flow in the building permit } \\
\text { process. }\end{array}$ & r8 & T3 & B1 & Closing & Sweden \\
\hline $\begin{array}{l}\text { Chognard } \\
\text { et al. [87] } \\
(2018)\end{array}$ & $\begin{array}{l}\text { Proposes a three-step translation protocol } \\
\text { to connect BIM and GIS domains. The third } \\
\text { steps is the import of the IFC file into GIS } \\
\text { data sets in order to update existing data } \\
\text { using FME software to convert IFC to GIS. }\end{array}$ & $\mathrm{r} 5, \mathrm{r} 11$ & T3 & B1 & Executing & Switzerland \\
\hline $\begin{array}{l}\text { KIRA- } \\
\text { digi [117] } \\
(2018)\end{array}$ & $\begin{array}{l}\text { Pilot study to automate building permit and } \\
\text { import BIM models into city models involv- } \\
\text { ing three cities in Finland }\end{array}$ & r2 & P1, T3 & B1 & Executing & Finland \\
\hline $\begin{array}{l}\text { İsmail and } \\
\text { Hamoud } \\
{[115]} \\
(2021)\end{array}$ & $\begin{array}{l}\text { Overview of Dubai BIM Roadmap project to } \\
\text { enable automated DBPs and updates of 3D } \\
\text { city models with BIM models }\end{array}$ & r2 & T1 & B1 & $\begin{array}{l}\text { Definition } \\
\text { and Plan- } \\
\text { ning }\end{array}$ & UAE \\
\hline
\end{tabular}

Table A.10: Classification of contributions related to the Step 6, i.e., conversion to and integration with a $3 \mathrm{D}$ city model or geoinformation

\begin{tabular}{|l|l|l|l|l|l|l|}
\hline \multicolumn{2}{|c|}{ Step 7 } & AR & AA & KoC & Progress & Country \\
\hline Entry & Description & & & The \\
\hline $\begin{array}{l}\text { Noardo } \\
\text { et al. [70] } \\
\text { (2020) }\end{array}$ & $\begin{array}{l}\text { The check of the dimensions regulation in } \\
\text { a case study in Rotterdam is investigated } \\
\text { and a tool is developed to check compli- } \\
\text { ance starting from the IFC model. }\end{array}$ & $\begin{array}{l}\mathrm{r10,r3,} \\
\mathrm{r9}\end{array}$ & T3 & B1 & Closing & $\begin{array}{l}\text { Nether- } \\
\text { lands }\end{array}$ \\
\hline
\end{tabular}




\begin{tabular}{|c|c|c|c|c|c|c|}
\hline $\begin{array}{l}\text { Ghannad } \\
\text { et al. [113] } \\
(2019)\end{array}$ & $\begin{array}{l}\text { The modularized framework that con- } \\
\text { sists of VPL and LegalRuleML (LRML) } \\
\text { is proposed to achieve BIM-based semi- } \\
\text { automatic rule checking, and the case stud- } \\
\text { ies that investigates example rules, namely } \\
\text { minimum area of room and circulation path, } \\
\text { from International Residential Code (ICC) } \\
\text { are presented. }\end{array}$ & $\begin{array}{l}r 4, r 5, \\
r 8, r 11\end{array}$ & $\mathrm{R} 1, \mathrm{R} 2$ & $\mathrm{~A} 2$ & Closing & USA \\
\hline $\begin{array}{l}\text { Kim } \\
\text { et al. [33] } \\
(2020)\end{array}$ & $\begin{array}{l}\text { The e-permitting framework consisting of } \\
\text { code checking, submission, pre-checking, } \\
\text { and automated rule-making modules is de- } \\
\text { veloped based on the Korea BIM (KBIM), } \\
\text { and the developed system is tested using } \\
\text { an office building in South Korea. }\end{array}$ & $\begin{array}{l}r 2, \quad r 5, \\
r 11\end{array}$ & $\begin{array}{l}\text { T1, T2, } \\
\text { T3 }\end{array}$ & B1 & Validating & $\begin{array}{l}\text { South Ko- } \\
\text { rea }\end{array}$ \\
\hline $\begin{array}{l}\text { Kincelova } \\
\text { et al. [125] } \\
(2019)\end{array}$ & $\begin{array}{l}\text { The available tools useful to check fire } \\
\text { safety regulations are tested and com- } \\
\text { pared. }\end{array}$ & $r 11$ & T3 & $\mathrm{A} 1$ & Executing & $\begin{array}{l}\text { Canada/ } \\
\text { Int }\end{array}$ \\
\hline $\begin{array}{l}\text { Olsson } \\
\text { et al. [114] } \\
(2018)\end{array}$ & $\begin{array}{l}\text { Some regulations (Building area, Maximum } \\
\text { height, visual checking in the context) are } \\
\text { checked by means of Safe software FME } \\
\text { scripts. }\end{array}$ & r5 & T3 & $\mathrm{A} 2$ & Closing & Sweden \\
\hline $\begin{array}{l}\text { Luo and } \\
\text { Gong } \\
{[127]} \\
(2015)\end{array}$ & $\begin{array}{l}\text { Addresses the whole workflow for deep } \\
\text { foundation design checks, including regu- } \\
\text { lations checks. }\end{array}$ & r4, r10 & R2, T3 & A2 & Validating & China \\
\hline $\begin{array}{l}\text { Van Berlo } \\
\text { et al. [71] } \\
(2013)\end{array}$ & $\begin{array}{l}\text { Proposes the check of some Dutch regula- } \\
\text { tions by means of GeoBIM integration and } \\
\text { conversion of regulation data into spatial } \\
\text { format (IFC) and discusses the experiment. }\end{array}$ & $\begin{array}{l}r 3, r 4, \\
r 5, r 11\end{array}$ & R1, T3 & A2 & Closing & $\begin{array}{l}\text { The } \\
\text { Nether- } \\
\text { lands }\end{array}$ \\
\hline $\begin{array}{l}\text { Balaban } \\
\text { et al. [126] } \\
(2013)\end{array}$ & $\begin{array}{l}\text { Prototype for automated code checking of } \\
\text { fire regulations in Turkey. Building code } \\
\text { (fire regulation) were translated to ma- } \\
\text { chine readable format (XML) and regula- } \\
\text { tions were checked on an IFC model. }\end{array}$ & r4 & P1 & B1 & $\begin{array}{l}\text { Definition } \\
\text { and Plan- } \\
\text { ning }\end{array}$ & Turkey \\
\hline $\begin{array}{l}\text { Eriksson } \\
\text { et al. [85] } \\
(2020)\end{array}$ & $\begin{array}{l}\text { Creates a proposal for a national Swedish } \\
\text { 3D city building standard as a CityGML } 3.0 \\
\text { ADE. Test data were created and a pro- } \\
\text { totype is developed to perform automated } \\
\text { check of three building permit regulations } \\
\text { according to the valid detailed development } \\
\text { plan where the building is planned. }\end{array}$ & r8, r10 & T3 & B1 & Validating & Sweden \\
\hline $\begin{array}{l}\text { Nguyen } \\
\text { and } \\
\text { Kim [93] } \\
(2011)\end{array}$ & $\begin{array}{l}\text { A tool is developed through the Revit API } \\
\text { to check the parameters of a BIM there de- } \\
\text { signed related to some parte of the Interna- } \\
\text { tional Building Code, particularly related to } \\
\text { fire safety. }\end{array}$ & $r 4, r 11$ & T3 & B1 & Closing & USA/ Int \\
\hline $\begin{array}{l}\text { Yang and } \\
\mathrm{Xu} \quad[132] \\
(2004)\end{array}$ & $\begin{array}{l}\text { Describes the implementation of a pro- } \\
\text { totype (Java environment) for automated } \\
\text { building code checking. Use an object- } \\
\text { based representation model for building } \\
\text { code knowledge. The model is described } \\
\text { in an earlier paper, focus here is implemen- } \\
\text { tation. }\end{array}$ & $\mathrm{r} 4, \mathrm{r} 11$ & T3 & B1 & $\begin{array}{l}\text { Definition } \\
\text { and Plan- } \\
\text { ning }\end{array}$ & Singapore \\
\hline $\begin{array}{l}\text { Hjelseth } \\
{[130]} \\
(2015)\end{array}$ & $\begin{array}{l}\text { Investigates the current approaches for } \\
\text { BIM-based code compliance checking by } \\
\text { interviewing with AEC companies. }\end{array}$ & r4, r10 & Т3 & $\mathrm{A} 1$ & Closing & Norway \\
\hline $\begin{array}{l}\text { Choi and } \\
\text { Kim }[109] \\
(2017)\end{array}$ & $\begin{array}{l}\text { Develops a multipartite, web-based system } \\
\text { that enables automatically checking of rule } \\
\text { compliance of the buildings based on IFC } \\
\text { data. }\end{array}$ & r4 & T2, T3 & B1 & Validating & $\begin{array}{l}\text { South Ko- } \\
\text { rea }\end{array}$ \\
\hline $\begin{array}{l}\text { Kasim } \\
\text { et al. [124] } \\
(2018)\end{array}$ & $\begin{array}{l}\text { Develops a system that allows automatic } \\
\text { compliance checking of building designs in } \\
\text { terms of their sustainability using IFC data } \\
\text { and XML files that are prepared by RASE } \\
\text { strategy. }\end{array}$ & $r 4, r 5$ & T3 & C & $\begin{array}{l}\text { Conception } \\
\text { and Initia- } \\
\text { tion }\end{array}$ & UK \\
\hline
\end{tabular}




\begin{tabular}{|c|c|c|c|c|c|c|}
\hline $\begin{array}{l}\text { Dimyadi } \\
\text { et al. [135] } \\
(2016)\end{array}$ & $\begin{array}{l}\text { Proposes to use of Visual Code Checking } \\
\text { Language, which is based on VPL, for de- } \\
\text { picting and checking rules in the building } \\
\text { codes in the context of automatic compli- } \\
\text { ance checking. The usability of the pro- } \\
\text { posed approach is demonstrated with two } \\
\text { different rules related to smoke ventilation } \\
\text { area and location of the stairs that directly } \\
\text { reach to shelter in buildings. }\end{array}$ & r4 & P1, T3 & B1 & Executing & $\begin{array}{l}\text { Germany/ } \\
\text { Korea/ Int }\end{array}$ \\
\hline $\begin{array}{l}\text { Hjelseth } \\
\text { [5] (2016) }\end{array}$ & $\begin{array}{l}\text { Provides the classification of BIM-based } \\
\text { model checking concepts as two main key } \\
\text { concepts (compliance checking and design } \\
\text { solution checking) and their counterparts } \\
\text { (validation checking and content checking, } \\
\text { smart object checking and design option } \\
\text { checking) to help the forming common un- } \\
\text { derstanding in use. }\end{array}$ & r8, r9 & $\mathrm{P} 1, \mathrm{R} 2$ & $\mathrm{~A} 2$ & Closing & Int \\
\hline $\begin{array}{l}\text { Zhang and } \\
\text { El-Gohary } \\
{[77]} \\
(2017)\end{array}$ & $\begin{array}{l}\text { Develops an integrated system that trans- } \\
\text { forms building codes into logic rules using } \\
\text { NLP and allows for automatic checking of } \\
\text { these rules by using EXPRESS data. }\end{array}$ & r4 & T3 & B1 & Validating & USA/Int \\
\hline $\begin{array}{l}\text { Lee et al. } \\
{[131]} \\
(2015)\end{array}$ & $\begin{array}{l}\text { Proposes the use of extended BERA lan- } \\
\text { guage approach to check the building de- } \\
\text { sign in terms of visibility and accessibil- } \\
\text { ity by exemplifying the proposed approach } \\
\text { for IFC data model of design of a hospital } \\
\text { building. }\end{array}$ & $r 11$ & T3 & B1 & $\begin{array}{l}\text { Definition } \\
\text { and Plan- } \\
\text { ning }\end{array}$ & USA \\
\hline $\begin{array}{l}\text { Solihin } \\
\text { and East- } \\
\text { man [169] } \\
(2016)\end{array}$ & $\begin{array}{l}\text { Proposes conceptual graph to represent } \\
\text { the rule requirements such that they can be } \\
\text { easily understood by rule experts and vali- } \\
\text { dates the proposed approach by using pre- } \\
\text { viously applied compliance checking with } \\
\text { respect to visibility of patient rooms from } \\
\text { nurse station. }\end{array}$ & r4, r9 & $\begin{array}{l}\text { R1, } \\
\text { R2, T3 }\end{array}$ & $\mathrm{A} 2$ & Closing & $\begin{array}{l}\text { South Ko- } \\
\text { rea }\end{array}$ \\
\hline $\begin{array}{l}\text { Pauwels } \\
\text { et al. [123] } \\
(2011)\end{array}$ & $\begin{array}{l}\text { Proposes the use of semantic web tech- } \\
\text { nologies for IFC-based rule checking. }\end{array}$ & r4 & P1, T3 & $\mathrm{A} 2$ & Closing & Belgium \\
\hline $\begin{array}{l}\text { Ingenieros } \\
{[120]} \\
(2021)\end{array}$ & $\begin{array}{l}\text { CYPEURBAN is a software developed to } \\
\text { verify the compliance of BIM Models in } \\
\text { IFC format against the Municipality Urban } \\
\text { Plan. CYPEURBAN has been developed } \\
\text { by CYPE with the support of the Associa- } \\
\text { tion of Real Estate in Madrid (ASPRIMA). }\end{array}$ & $\begin{array}{l}r 1, \quad r 2 \\
r 3, \quad r 6 \\
r 10\end{array}$ & $\begin{array}{l}\text { P1, } \\
\text { R2, T3 }\end{array}$ & C & Closing & Spain/ Int \\
\hline $\begin{array}{l}\text { TNO [168] } \\
(2018)\end{array}$ & $\begin{array}{l}\text { TNO is developing a new eco-system to } \\
\text { make it possible to perform a fully auto- } \\
\text { matic code checking of Buildings regula- } \\
\text { tions based on analytic checking principles } \\
\text { and machine learning techniques. }\end{array}$ & $\mathrm{r} 2, \mathrm{r} 11$ & $\mathrm{P} 1$ & B1 & $\begin{array}{l}\text { Definition } \\
\text { and Plan- } \\
\text { ning }\end{array}$ & $\begin{array}{l}\text { The } \\
\text { Nether- } \\
\text { lands, } \\
\text { National, } \\
\text { Int }\end{array}$ \\
\hline $\begin{array}{l}\text { Johansson } \\
{[105]} \\
(2020)\end{array}$ & $\begin{array}{l}\text { Development of a prototype to check if a } \\
\text { building follows a few building permit reg- } \\
\text { ulations based on IFC-model and geodata } \\
\text { (detailed development plan) imported to an } \\
\text { FME environment where the checks are } \\
\text { performed. }\end{array}$ & r8 & T3 & B1 & Closing & Sweden \\
\hline $\begin{array}{l}\text { Narayanswa } \\
\text { et al. [6] } \\
(2019)\end{array}$ & $\begin{array}{l}\text { The development of a prototype to au- } \\
\text { ny tomate municipal bylaw and wall framing } \\
\text { code compliance checking for residential } \\
\text { building is presented }\end{array}$ & $\begin{array}{l}r 4, \quad r 5 \\
\text { r6 }\end{array}$ & $\mathrm{P} 1$ & B1 & Executing & $\begin{array}{l}\text { USA, } \\
\text { Canada }\end{array}$ \\
\hline $\begin{array}{l}\text { Kim } \\
\text { et al. [90] } \\
(2017)\end{array}$ & $\begin{array}{l}\text { Describes the development KBimLogic, a } \\
\text { rule-based mechanism designed for the } \\
\text { building permit related rules in Korea Build- } \\
\text { ing Act sentences. As a computer-readable } \\
\text { definition of a rule, KBimCode has been } \\
\text { developed to be executed in actual rule- } \\
\text { checking software. }\end{array}$ & r4 & T3 & B2 & Executing & $\begin{array}{l}\text { South Ko- } \\
\text { rea }\end{array}$ \\
\hline
\end{tabular}




\begin{tabular}{|c|c|c|c|c|c|c|}
\hline $\begin{array}{l}\text { Park et al. } \\
{[121]} \\
(2015)\end{array}$ & $\begin{array}{l}\text { Describes rule checking method, classifica- } \\
\text { tion and its demonstration with actual re- } \\
\text { quirement sentences from the Korea Build- } \\
\text { ing Permit as part of KBimLogic, a software } \\
\text { that translates the Korea Building Permit } \\
\text { requirement into computer-executable for- } \\
\text { mat. }\end{array}$ & $\begin{array}{l}r 10 \\
r 11\end{array}$ & $\mathrm{P} 1$ & $\mathrm{~A} 2$ & Executing & $\begin{array}{l}\text { South Ko- } \\
\text { rea }\end{array}$ \\
\hline $\begin{array}{l}\text { Krijnen } \\
\text { and Van } \\
\text { Berlo } \\
{[166]} \\
(2016)\end{array}$ & $\begin{array}{l}\text { A general overview of technologies for re- } \\
\text { quirement checking on building (IFC) mod- } \\
\text { els. Describes how one example require- } \\
\text { ment can be formalized and queries an } \\
\text { IFC-model as a demonstration. }\end{array}$ & r3, r11 & T3 & $\mathrm{A} 2$ & $\begin{array}{l}\text { Conception } \\
\text { and Initia- } \\
\text { tion }\end{array}$ & $\begin{array}{l}\text { The } \\
\text { Nether- } \\
\text { lands }\end{array}$ \\
\hline $\begin{array}{l}\text { Zhou and } \\
\text { El-Gohary } \\
{[122]} \\
(2019)\end{array}$ & $\begin{array}{l}\text { The BIM of an educational building was } \\
\text { checked for compliance with three energy } \\
\text { codes }\end{array}$ & r3, r10 & $\mathrm{R} 2$ & $\mathrm{~A} 2$ & Executing & USA \\
\hline $\begin{array}{l}\text { Song } \\
\text { et al. [134] } \\
(2020)\end{array}$ & $\begin{array}{l}\text { Proposed an approach that contributes to } \\
\text { broadening the cope of BIM-enabled rule } \\
\text { checking to any natural language-based } \\
\text { design requirements }\end{array}$ & r4 & $\mathrm{R} 2$ & $\mathrm{~A} 2$ & Executing & $\begin{array}{l}\text { South Ko- } \\
\text { rea }\end{array}$ \\
\hline $\begin{array}{l}\text { Zhang and } \\
\text { El-Gohary } \\
{[106]} \\
(2015)\end{array}$ & $\begin{array}{l}\text { Propose a BIM IE method to automatically } \\
\text { extract project information from IFC-based } \\
\text { BIMs and transform it into a logic format } \\
\text { (logic facts) that is ready to be automatically } \\
\text { checked against logic-represented regula- } \\
\text { tory rules (logic rules). }\end{array}$ & r3, r11 & T3 & $\mathrm{A} 2$ & Closing & USA \\
\hline $\begin{array}{l}\text { Beach } \\
\text { et al. [170] } \\
(2015)\end{array}$ & $\begin{array}{l}\text { Proposes an approach that enhances the } \\
\text { RASE methodology by benefiting from } \\
\text { SWRL and IFC for automated compliance } \\
\text { checking. Case study is conducted using a } \\
\text { developed plug in Bentley Microstation. }\end{array}$ & $\mathrm{r} 4, \mathrm{r} 8$ & R1, T3 & B1 & Validating & UK \\
\hline $\begin{array}{l}\text { Zhong } \\
\text { et al. [133] } \\
(2018)\end{array}$ & $\begin{array}{l}\text { Proposes a methodology that automati- } \\
\text { cally checks environmental conditions of } \\
\text { the buildings against regulations by using } \\
\text { sensor data and SPARQL. }\end{array}$ & $\mathrm{r} 4, \mathrm{r} 11$ & R1, T3 & B1 & Validating & China \\
\hline $\begin{array}{l}\text { Kincelova } \\
\text { et al. [91] } \\
(2020)\end{array}$ & $\begin{array}{l}\text { Developes a Dynamo script that automat- } \\
\text { ically checks regulations related to fire } \\
\text { safety in the Canadian context. }\end{array}$ & $\mathrm{r} 4, \mathrm{r} 11$ & R1, T3 & B1 & Validating & Canada \\
\hline $\begin{array}{l}\text { Ciribini } \\
\text { et al. [108] } \\
(2016)\end{array}$ & $\begin{array}{l}\text { Translates the building code of the Munici- } \\
\text { pality of Milan in a set of parametric rules to } \\
\text { validate BIM models in SMC. }\end{array}$ & $r 11$ & T3 & B2 & Executing & Italy \\
\hline $\begin{array}{l}\text { Tech [171] } \\
\text { (2021) }\end{array}$ & $\begin{array}{l}\text { Software for building plan code compliance } \\
\text { and digitally managing building permitting } \\
\text { process based on Artificial intelligence and } \\
\text { GIS-BIM integration. }\end{array}$ & r5 & P1, T3 & B2 & Executing & Int \\
\hline $\begin{array}{l}\text { Zhang } \\
{[119]} \\
(2019)\end{array}$ & $\begin{array}{l}\text { MSc thesis checking two building permit } \\
\text { regulatons in geodata environment (FME). }\end{array}$ & r5, r6 & T3 & B1 & Closing & Sweden \\
\hline $\begin{array}{l}\text { Estonia } \\
\text { Ministry of } \\
\text { Economic } \\
\text { Affairs \& } \\
\text { Commu- } \\
\text { nications } \\
{[102]} \\
(2021)\end{array}$ & $\begin{array}{l}\text { Development of a software solution for BIM- } \\
\text { based building permit processes in the Es- } \\
\text { tonian Building Registry. }\end{array}$ & r2 & T3 & B1 & Executing & Estonia \\
\hline $\begin{array}{l}\text { Alli and } \\
\text { Rognoni } \\
{[172]} \\
(2021)\end{array}$ & $\begin{array}{l}\text { Description on how to use SMC to verify the } \\
\text { compliance with the Building permit Code. }\end{array}$ & $r 11$ & T3 & B2 & Executing & Int \\
\hline $\begin{array}{l}\text { Jialun } \\
{[118]} \\
(2021) \\
\end{array}$ & $\begin{array}{l}\text { MSc thesis proposing the checking of park- } \\
\text { ing regulations by means of the } 3 D \text { city } \\
\text { model, in CityJSON. }\end{array}$ & r5, r11 & T3 & B1 & Closing & $\begin{array}{l}\text { The } \\
\text { Nether- } \\
\text { lands }\end{array}$ \\
\hline
\end{tabular}


Table A.11: Classification of contributions related to the Step 7, i.e., application reviewed (content - regulations checks).

\begin{tabular}{|c|c|c|c|c|c|c|}
\hline \multicolumn{7}{|c|}{ Step 8} \\
\hline Entry & Description & AR & AA & KoC & Progress & Country \\
\hline $\begin{array}{l}\text { City of } \\
\text { Sant Fe- } \\
\text { liu }[137] \\
(2021)\end{array}$ & $\begin{array}{l}\text { Development of a web-based platform to } \\
\text { support the City of Sant Feliu in ecoming a } \\
\text { Smart City. Services under developments } \\
\text { include also application for actively involv- } \\
\text { ing the citizen in the process of city plan- } \\
\text { ning. }\end{array}$ & $\begin{array}{l}r 1, \quad r 2, \\
r 10\end{array}$ & $\begin{array}{l}\text { E1, } \\
\text { P1, } \\
\text { T2, T3 }\end{array}$ & B1 & Validating & Spain \\
\hline $\begin{array}{l}\text { Chognard } \\
\text { et al. [87] } \\
(2018)\end{array}$ & $\begin{array}{l}\text { Describes the development of a digital con- } \\
\text { struction permit submission procedure for } \\
\text { the canton of Geneva in Switzerland. }\end{array}$ & $r 5, r 11$ & T3 & B1 & Executing & Switzerland \\
\hline
\end{tabular}

Table A.12: Classification of contributions related to the Step 8, i.e., completion of the work and building authorities notification. 